Prepared in cooperation with the Bureau of Reclamation and U.S. Fish and Wildlife Service

\title{
Water-Quality Conditions in Upper Klamath Lake, Oregon, 2002-04
}

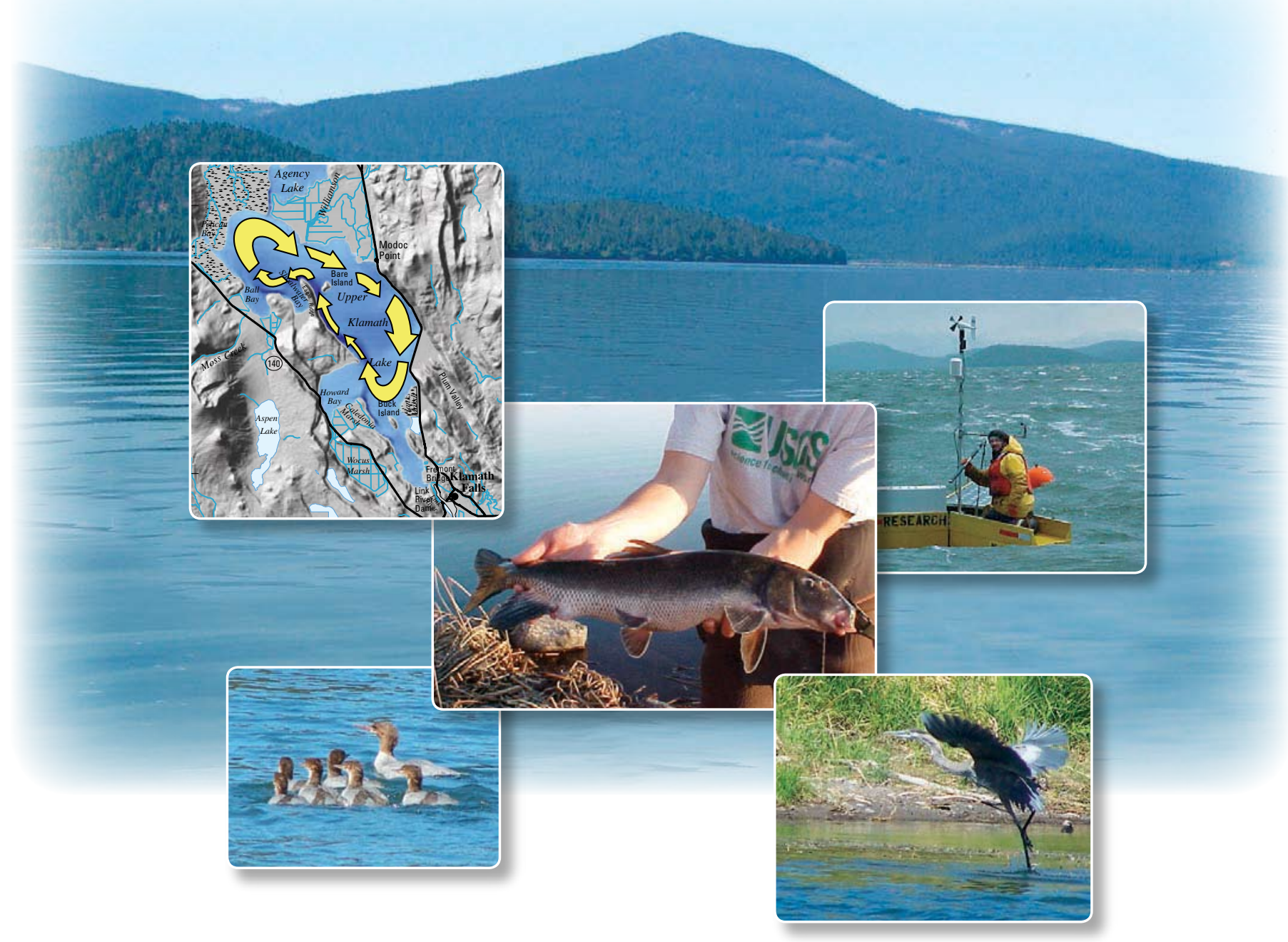

Scientific Investigations Report 2006-5209 
Cover: Upper Klamath Lake looking west toward Eagle Ridge. (Photograph taken by Mary Lindenberg, U.S. Geological Survey, Klamath Falls, Oregon, 2006.) Insets from left to right are:

Inset 1: Photograph of mom and baby Mergansers in Upper Klamath Lake. (Photograph taken by Mary Lindenberg, U.S. Geological Survey, Klamath Falls, Oregon, 2006.)

Inset 2: Photograph of Lost River sucker from Upper Klamath Lake. (Photograph taken by Brian Hayes, U.S. Geological Survey, Klamath Falls, Oregon, date unknown.)

Inset 3: Photograph of the buoy platform supporting the meteorological and water quality instrumentation at U.S. Geological Survey site MDL on Upper Klamath Lake, Oregon. (Photograph taken by Pamela Burns, U.S. Geological Survey, Klamath Falls, Oregon, 2005.)

Inset 4: Photograph of Great Blue Heron taking off, Upper Klamath Lake. (Photograph taken by Mary Lindenberg, U.S. Geological Survey, Klamath Falls, Oregon, 2006.) 


\section{Water-Quality Conditions in Upper Klamath Lake, Oregon, 2002-04}

By Tamara M. Wood, Gene R. Hoilman, and Mary K. Lindenberg

Prepared in cooperation with the

Bureau of Reclamation and the U.S. Fish and Wildlife Service

Scientific Investigations Report 2006-5209 


\section{U.S. Department of the Interior \\ Dirk A. Kempthorne, Secretary \\ U.S. Geological Survey \\ P. Patrick Leahy, Acting Director}

U.S. Geological Survey, Reston, Virginia: 2006

For sale by U.S. Geological Survey, Information Services
Box 25286, Denver Federal Center
Denver, CO 80225
For more information about the USGS and its products:
Telephone: 1-888-ASK-USGS
World Wide Web: http://www.usgs.gov/

\footnotetext{
Any use of trade, product, or firm names in this publication is for descriptive purposes only and does not imply endorsement by the U.S. Government.

Although this report is in the public domain, permission must be secured from the individual copyright owners to reproduce any copyrighted materials contained within this report.

Suggested citation:

Wood, T.M., Hoilman, G.R., and Lindenberg, M.K., 2006, Water-quality conditions in Upper Klamath Lake, Oregon, 2002-04: U.S. Geological Survey Scientific Investigations Report 2006-5209, 52 p.
} 


\section{Contents}

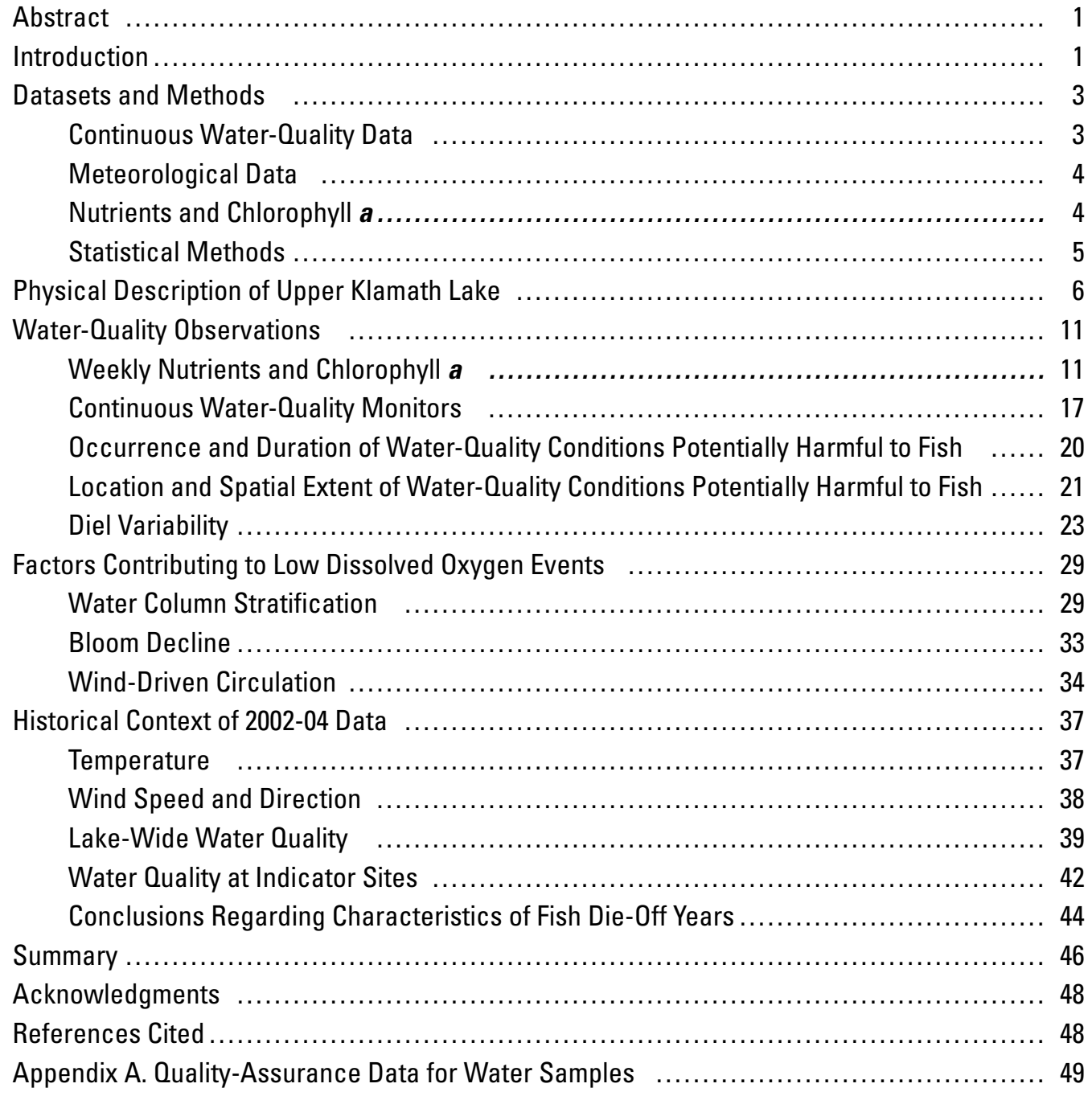




\section{Figures}

Figure 1. Maps showing Upper Klamath Lake, with locations of continuous water-quality monitors, acoustic Doppler current profilers, and water sample-collection sites in (A) 2002 and (B) 2003-04, Klamath County, Oregon

Figure 2. Graphs showing daily maximum range in temperature over the water column, minimum range in temperature over the water column, maximum temperature, and minimum temperature, from hourly values collected at 1 meter off the bottom and 1 meter from the surface at sites UKL07 and UKL08 in Upper Klamath Lake, Oregon, 2002

Figure 3. Graphs showing daily maximum range in temperature over the water column, minimum range in temperature over the water column, maximum temperature, and minimum temperature, from hourly values collected at 1 meter off the bottom and 1 meter from the surface at sites UKL07 and UKL13 in Upper Klamath Lake, Oregon, 2003

Figure 4. Graphs showing daily maximum range in temperature over the water column, minimum range in temperature over the water column, maximum temperature, and minimum temperature, from hourly values collected at 1 meter off the bottom and 1 meter from the surface at sites UKL07 and UKL16 in Upper Klamath Lake, Oregon, 2004

Figure 5. Graph showing depth of the photic zone (the depth where light is 1 percent of surface value), as a function of chlorophyll a concentration in Upper Klamath Lake, Oregon

Figure 6. Graphs showing half-hourly current speed and direction recorded at sites ADCP4 and ADCP8, Upper Klamath Lake, Oregon, 2003

Figure 7. Graphs showing half-hourly current speed and direction recorded at sites ADCP1 and ADCP2 (before August 6) and at sites ADCP3 and ADCP4 (after August 6), Upper Klamath Lake, Oregon, 2004

Figure 8. Map showing circulation pattern in Upper Klamath Lake in response to prevailing wind conditions.

Figure 9. Graphs showing chlorophyll a concentrations at sites in Upper Klamath Lake, Oregon, 2002-04

Figure 10. Graphs showing total phosphorus concentrations at sites in Upper Klamath Lake, Oregon, 2002-04

Figure 11. Graphs showing orthophosphate-P concentrations at sites in Upper Klamath Lake, Oregon, 2002-04

Figure 12. Graphs showing ammonia-N concentrations at sites in Upper Klamath Lake, Oregon, 2002-04

Figure 13. Graphs showing un-ionized ammonia-N concentrations at sites in Upper Klamath Lake, Oregon, 2002-04

Figure 14. Graphs showing nitrate/nitrite-N concentrations at sites in Upper Klamath Lake, Oregon, 2002-04

Figure 15. Boxplots showing statistical distributions of chlorophyll $a$, total phosphorus, and ammonia- $\mathrm{N}$ concentrations for the entire field season at individual sites in Upper Klamath Lake, Oregon, 2002-04

Figure 16. Graphs showing daily medians of $(A)$ percent saturation of dissolved oxygen, $(B)$ dissolved oxygen concentration, $(C) \mathrm{pH}$, and $(D)$ temperature for sites in Upper Klamath Lake, Oregon, 2002-04 


\section{Figures-Continued}

Figure 17. Graphs showing percentage of sites recording at least one reading in the day of conditions potentially harmful to fish in Upper Klamath Lake, Oregon, 2002-04

Figure 18. Graphs showing percentage of total site-hours in the day having conditions potentially harmful to fish in Upper Klamath Lake, Oregon, 2002-04 ....

Figure 19. Maps showing Geographic Information System coverage of an interpolation of weekly median dissolved oxygen concentrations, Julian weeks 31-34, Upper Klamath Lake, Oregon, 2002-04

Figure 20. Maps showing Geographic Information System coverage of an interpolation of weekly median $\mathrm{pH}$, Julian week 27, Upper Klamath Lake, Oregon, 2002-04

Figure 21. Maps showing Geographic Information System coverage of an interpolation of weekly median temperature, Julian week 31, Upper Klamath Lake, Oregon, 2002-04

Figure 22. Histograms showing daily extremes in water-quality conditions as a function of hour in the day, at representative shallow (UKL02) and deep (UKL07) sites in Upper Klamath Lake, Oregon, 2002-04. Data for 2002-04 have been combined....

Figure 23. Graphs showing daily minimum and maximum ranges in dissolved oxygen over the water column and minimum and maximum dissolved oxygen from hourly values collected at 1 meter off the bottom and 1 meter from the surface at sites UKL07 and UKL08 in Upper Klamath Lake, Oregon, 2002

Figure 24. Graphs showing daily minimum and maximum ranges in dissolved oxygen over the water column and minimum and maximum dissolved oxygen from hourly values collected at 1 meter off the bottom and 1 meter from the surface at sites UKL07 and UKL13 in Upper Klamath Lake, Oregon, 2003

Figure 25. Graphs showing daily minimum and maximum ranges in dissolved oxygen over the water column and minimum and maximum dissolved oxygen from hourly values collected at 1 meter off the bottom and 1 meter from the surface at sites UKL07 and UKL16 in Upper Klamath Lake, Oregon, 2004

Figure 26. Graphs showing daily maximum range in dissolved oxygen concentration over the water column, maximum range in temperature over the water column, minimum water column dissolved oxygen concentration, and $90^{\text {th }}$ percentile of hourly wind values in Upper Klamath Lake, Oregon, 2002-04

Figure 27. Graph showing daily median dissolved oxygen concentrations at sites UKL04, UKL07, UKL13, and UKL14 in Upper Klamath Lake, Oregon, 2003

Figure 28. Graph showing daily median dissolved oxygen concentrations at sites UKL04, UKL07, UKL13, and UKL14 in Upper Klamath Lake, Oregon, 2004

Figure 29. Graphs showing hourly dissolved oxygen concentrations at sites UKL14 and UKL16 in Upper Klamath Lake, Oregon, 2004 ....

Figure 30. Graph showing hourly dissolved oxygen concentrations at site UKL14 in Upper Klamath Lake, Oregon, 2003

Figure 31. Graphs showing July-August distributions of concentrations of chlorophyll $a$, ammonia, dissolved oxygen, and temperature, and the difference between the water column maximum and minimum dissolved oxygen, at three sites located in Upper Klamath Lake, Oregon 


\section{Figures-Continued}

Figure 32. Scatter plots showing correlation between the July-August averaged wind speed at the Klamath Falls Airport and the median of the July-August distribution of ammonia, dissolved oxygen, and the difference between water column maximum and minimum dissolved oxygen, Upper Klamath Lake, Oregon

Figure 33. Scatter plots showing principal component scores for data from Midnorth site, all July and August sample dates, Upper Klamath Lake, Oregon, 1990-2004

Figure 34. Scatter plots showing principal component scores for data from Eagle Ridge site, all July and August sample dates, Upper Klamath Lake, Oregon, 1990-2004

\section{Tables}

Table 1. Water column depths at the beginning of the summer months at sites where profiling buoys were located, Upper Klamath Lake, Oregon, 2002-04 ............ 8

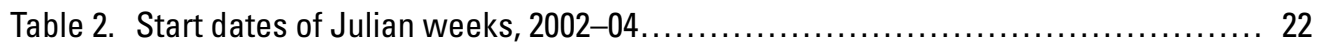

Table 3. Spatial extent of extreme water-quality conditions in Upper Klamath Lake, Oregon, 2002-04

Table 4. Average number of hours per day in Julian weeks 31 to 34 that dissolved oxygen concentrations less than 4 milligrams per liter were measured at shallow and deep sites in Upper Klamath Lake, Oregon, 2002-04

Table 5. Average number of hours per day in Julian week 27 that $\mathrm{pH}$ greater than 9.7 was measured at shallow and deep sites in Upper Klamath Lake, Oregon, 2002-04

Table 6. Dates of low dissolved oxygen events in the northern part of Upper Klamath Lake, Oregon, 2002-03

Table 7. Spearman's rho correlation coefficients between daily values derived from hourly data collected at site UKL08 in 2002 and site UKL07 in 2003-04, Upper Klamath Lake, Oregon

Table 8. Results of analysis of variance (ANOVA) of air temperature at the Klamath Falls Airport, Oregon, July and August, 1990-2004

Table 9. Results of analysis of variance (ANOVA) of wind speed at the Klamath Falls Airport, Oregon, July and August, 1990-2004

Table 10. Results of analysis of variance (ANOVA) of the along-lake component of wind speed at the Klamath Falls Airport, Oregon, July and August, 1990-2004

Table 11. Results of analysis of variance (ANOVA) of wind speed at the Klamath Falls Airport and at the Bureau of Reclamation Agrimet site located at Agency Lake, Oregon, July and August, 1990-2004

Table 12. Spearman's rho correlation coefficients between selected water-quality and climate variables in Upper Klamath Lake Basin, Oregon, 1990-2004

Table 13. Principal component scores at sites Eagle Ridge and Midnorth in Upper Klamath Lake, Oregon 


\section{Tables-Continued}

Table 14. Distribution statistics of water column averages of chlorophyll $a$, ammonia-N, dissolved oxygen, and temperature at Eagle Ridge site, based on July-August sampling dates, Upper Klamath Lake, Oregon, 1990-2004

Table 15. Distribution statistics of water column averages of chlorophyll $a$, ammonia- $\mathrm{N}$, dissolved oxygen, and temperature at Midnorth site, based on July-August sampling dates, Upper Klamath Lake, Oregon, 1990-2004

\section{Conversion Factors, Datums, and Abbreviations and Symbols}

SI to Inch/Pound

\begin{tabular}{lcl}
\hline Multiply & By & To obtain \\
\hline centimeter per second $(\mathrm{cm} / \mathrm{s})$ & 0.0328 & foot per second \\
cubic meter per second $\left(\mathrm{m}^{3} / \mathrm{s}\right)$ & 70.07 & acre-foot per day \\
kilometer $(\mathrm{km})$ & 0.6214 & mile \\
liter $(\mathrm{L})$ & 1.057 & quart \\
liter $(\mathrm{L})$ & 0.2642 & gallon \\
meter $(\mathrm{m})$ & 3.281 & foot \\
square kilometer $\left(\mathrm{km}^{2}\right)$ & 0.3861 & square mile \\
square meter $\left(\mathrm{m}^{2}\right)$ & 0.0002471 & acre \\
\hline
\end{tabular}

Temperature in degrees Celsius $\left({ }^{\circ} \mathrm{C}\right)$ may be converted to degrees Fahrenheit $\left({ }^{\circ} \mathrm{F}\right)$ as follows:

${ }^{\circ} \mathrm{F}=\left(1.8 x^{\circ} \mathrm{C}\right)+32$.

\section{Datums}

Vertical coordinate information is referenced to North American Vertical Datum of 1988 (NAVD 88).

Horizontal coordinate information is referenced to the North American Datum of 1983 (NAD 83).

Altitude, as used in this report, refers to distance above the vertical datum. 


\section{Conversion Factors, Datums, and Abbreviations and Symbols-Continued}

Abbreviations and Symbols

\begin{tabular}{ll}
\hline Abbreviations and Symbols & Definition \\
\hline ADCP & acoustic Doppler current profiler \\
AFA & Aphanizomenon flos aquae \\
ANOVA & analysis of variance \\
BOD & biological oxygen demand \\
GIS & Geographic Information System \\
LDOE & low dissolved oxygen event \\
NWIS & National Water Information System \\
NWQL & National Water Quality Laboratory \\
Reclamation & Bureau of Reclamation \\
USFWS & U.S. Fish and Wildlife Service \\
USGS & U.S. Geological Survey \\
$\circ$ & degree \\
$\mathrm{mg} / \mathrm{L}$ & milligram per liter \\
$\mu \mathrm{g} / \mathrm{L}$ & microgram per liter \\
$\mu \mathrm{m}$ & micrometer \\
\hline
\end{tabular}




\title{
Water-Quality Conditions in Upper Klamath Lake, Oregon, 2002-04
}

\author{
By Tamara M. Wood, Gene R. Hoilman, and Mary K. Lindenberg
}

\section{Abstract}

Eleven (2002) to 14 (2003 and 2004) continuous waterquality monitors that measured $\mathrm{pH}$, dissolved oxygen, temperature, and specific conductance, were placed in Upper Klamath Lake to support a telemetry tracking study of endangered adult shortnose and Lost River suckers. Samples for the analysis of chlorophyll $a$ and nutrients were collected at a subset of the water-quality monitor sites in each year. The seasonal pattern in the occurrence of supersaturated dissolved oxygen concentrations and high $\mathrm{pH}$ associated with photosynthetic activity, as well as the undersaturated dissolved oxygen concentrations associated with oxygen demand through respiration and decay in excess of photosynthetic production, were well described by the dynamics of the massive blooms of Aphanizomenon flos aquae (AFA) that occur each year.

Data from the continuous monitors provided a means to quantify the occurrence, duration, and spatial extent of water-quality conditions potentially harmful to fish (dissolved oxygen concentration less than 4 milligrams per liter, $\mathrm{pH}$ greater than 9.7, and temperature greater than 28 degrees Celsius) in the northern part of the lake, where the preferred adult sucker habitat is found. There were few observations of temperature greater than 28 degrees Celsius, suggesting that temperature is not a significant source of chronic stress to fish, although its role in the spread of disease is harder to define. Observations of $\mathrm{pH}$ greater than 9.7 were common during times when the AFA bloom was growing rapidly, so $\mathrm{pH}$ may be a source of chronic stress to fish. Dissolved oxygen concentrations less than 4 milligrams per liter were common in all 3 years at the deeper sites, in the lower part of the water column and for short periods during the day. Less common were instances of widespread low dissolved oxygen, throughout the water column and persisting through the entire day, but this was the character of a severe low dissolved oxygen event (LDOE) that culminated in the start of a fish die-off in 2003.
Documented evidence indicates that LDOEs played a role in three fish die-offs in the mid-1990s as well. In the historical context of 15 years of climate and water-quality data, 3 out of 4 of the recent fish die-off years, 1996, 1997, and 2003, were characterized by low winds and high temperatures in July or August coincident with the start of the die-off. High temperatures accelerate the oxygen demanding processes that lead to a LDOE. The role of low winds remains inconclusive, but it could include the development of stratification in the water column and/or the alteration of the wind-driven circulation pattern.

At a site centrally located in the study area, die-off years could be successfully identified in the historical data by screening for water characterized by exceptionally low chlorophyll $a$ concentration, exceptionally low dissolved oxygen concentration throughout the water column (not just near the bottom), and exceptionally high ammonia concentration and water temperature, just prior to or coincident with the start of a fish die-off. These conditions indicate that a severe decline in the AFA bloom and conversion of most of the organic matter into inorganic form had taken place.

\section{Introduction}

Upper Klamath Lake (fig. 1) is located in southern Oregon; about $25 \mathrm{~km}$ north of the California-Oregon border and $18 \mathrm{~km}$ east of the crest of the Cascade Range. It is a large, relatively shallow lake with a surface area of $232 \mathrm{~km}^{2}$ and an average depth of $2.8 \mathrm{~m}$ at full pool. Most of the lake (92 percent) is shallower than $4 \mathrm{~m}$, with the exception of a narrow trench running parallel to Eagle Ridge, on the lake's western shore. This trench contains the deepest waters of the lake, approaching $15 \mathrm{~m}$. Upper Klamath Lake is located in the Klamath Graben structural valley, and much of its $9,415 \mathrm{~km}^{2}$ drainage basin is composed of phosphorus-rich volcanically derived soils. The largest single contributor of 


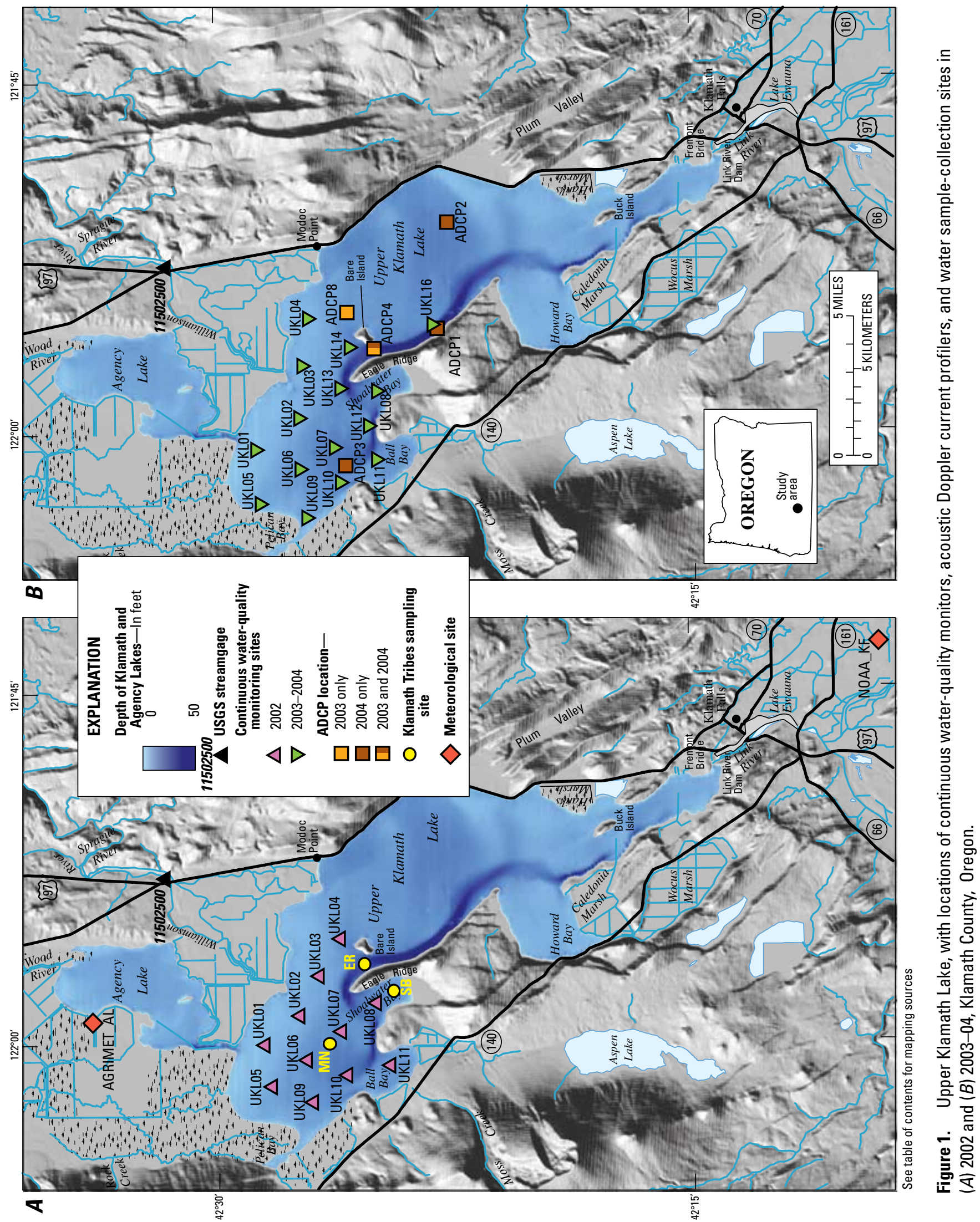


inflow to the lake is the Williamson River, which constitutes about 46 percent of the lake's incoming water and enters the lake near its northern end (Johnson and others, 1985). Agency Lake, just north of Upper Klamath Lake and connected to it by a narrow channel, has $37 \mathrm{~km}^{2}$ of surface area and an average depth of $2.2 \mathrm{~m}$, and is for the most part distinct from Upper Klamath Lake hydrologically and in terms of water quality. Upper Klamath Lake was historically eutrophic, but over the past several decades has experienced nuisance blooms of the blue-green alga Aphanizomenon flos-aquae (AFA) during the summer and autumn, and can now be characterized as hypereutrophic.

Upper Klamath Lake is a natural water body, but lake surface elevations have been regulated since 1921, when Link River Dam was completed at the southern outlet of the lake. The dam was built, and is currently operated, by the Bureau of Reclamation, and Upper Klamath Lake is now the principal water source for the Klamath Project-an irrigation system developed to supply water to $970 \mathrm{~km}^{2}$ of farm and ranch land in and around the Upper Klamath Basin. During the summer months, water is diverted upstream of the lake for agricultural use, water is diverted downstream to supply the irrigators of the Klamath Project, water is sent downstream through the Link River to meet the flow requirements of the National Marine Fisheries Service for Klamath River coho salmon, and water is lost from the lake through evaporation. As a result, the lake level declines by about $1 \mathrm{~m}$ between June 1 and September 1. Lake elevations during the 3 study years were $1262.71,1262.79$, and $1262.64 \mathrm{~m}$ on June 1 in 2002, 2003, and 2004, respectively. On September 1, the elevations were 1261.44, 1261.76, and $1261.72 \mathrm{~m}$ in 2002, 2003, and 2004, respectively (on the basis of data for U.S. Geological Survey (USGS) site identification No. 11507001, which is a weighted average of three gages located around the lake).

Severe water-quality problems in Upper Klamath Lake have led to critical fishery concerns for the region, including the listing of Lost River and shortnose suckers as endangered in 1988. The lake's algal community has shifted to a monoculture of AFA, massive blooms of which have been directly related to episodes of poor water quality. The growth and decomposition of dense algal blooms in the lake frequently cause extreme water quality conditions characterized by high $\mathrm{pH}(9-10)$, widely variable dissolved oxygen (anoxic to supersaturated), and high ammonia concentrations (greater than $0.5 \mathrm{mg} / \mathrm{L}$, un-ionized).

In April 2001, the U.S. Fish and Wildlife Service (USFWS) released a Biological Opinion regarding the endangered suckers in Upper Klamath Lake. As part of that document, the USFWS provided several alternatives to allow for the continued operation of the Klamath Project. One of those alternatives was for the Bureau of Reclamation (Reclamation) to develop a study plan to better determine the role of "water quality refuge" areas in adult sucker survival in Upper Klamath Lake. This led Reclamation and
U.S. Geological Survey (USGS) to enter into a cooperative agreement, the primary objective of which was to tag and track with radio telemetry a representative sample of the endangered suckers in the lake while simultaneously monitoring water quality. Water quality was monitored primarily through a network of multiparameter water quality instrumentation. The network was designed with the objective of being able to provide a "map" of water quality at any point in time, onto which the fish tracking information could be overlaid. Such a map would provide information about water quality not only where fish were located, but also where fish were not located, and would allow robust statistical tests of fish movement in response to water-quality conditions. The study area was limited to roughly the northern one-third of Upper Klamath Lake, largely because a previous tracking study done by Reclamation had indicated that the endangered suckers were located primarily in this area of the lake. The tracking data collected during this study has borne out that assumption.

The purpose of this report is to present the water quality information collected during the 3 years of the tracking study, along with a discussion of what has been learned about the factors determining water quality in Upper Klamath Lake. The results of the fish tracking in a water-quality context have been presented elsewhere (B.J. Adams, U.S. Geological Survey, unpub. data, 2005), but the wealth of information provided by the monitoring done in support of the tracking study, much of which went well beyond the original objectives, merits its own report.

\section{Datasets and Methods}

Three datasets that were collected by the USGS as part of the fish-tracking study have been used in preparing this report. The first is continuous dissolved oxygen, $\mathrm{pH}$, specific conductance, and water temperature collected from a network of continuous water-quality monitors, the second is meteorological data (wind, temperature, relative humidity) collected at two locations in the study area, and the third is chlorophyll $a$ and nutrient data collected on a weekly basis at a subset of the sites in the study area. An additional dataset of light-meter readings, collected just under the water surface and at $0.5-\mathrm{m}$ depth intervals at several sites around the lake as part of the ongoing monitoring effort in 2005, was used to generate estimates of the depth of the photic zone.

\section{Continuous Water-Quality Data}

In 2002, the water-quality monitoring network consisted of 11 sites in the study area (fig. $1 A$ ). At nine of these sites, the monitor was located in a fixed position at $1 \mathrm{~m}$ off the bottom. At two of these sites, the monitor was installed on a profiling buoy, which was programmed to make a profile of the water 
column on an hourly basis. Starting in 2003, the network was modified on the basis of 2002 results. Most of the sites were slightly relocated, and three were added (fig. 1B). In 2004, one of the profiling buoys was relocated to a position outside of the immediate study area, in the middle of the deep trench running along the western shoreline of the lake (site UKL16 in fig. 1B).

The water-quality monitors were cleaned and field measurements were collected during weekly site visits. Deployments generally lasted 3 weeks; at the end of this time, the monitor at the site was replaced with a freshly calibrated unit. Quality of the data was assured by collecting field information at weekly site visits and processing the time series according to the procedures in Wagner and others (2000). The maintenance procedure for the monitors at the profiling buoys was the same as for those at fixed positions, except that deployments generally lasted only 2 weeks.

Data collected from the profiling buoys provided information on the variability in water-quality constituents over the water column at a single geographic location. The vertical resolution of the profiles changed over the 3 years of the study as the understanding of the system and the objectives of the profiling data evolved. Profiling was based on a user-supplied uppermost depth and a sampling interval; therefore, as the lake was drawn down over the summer, the programming needed to be adjusted to compensate for the decreasing overall depth. This resulted in some imprecision in the location of the sampling depths relative to the bottom, but the buoys were consistently programmed to collect data as closely as could be achieved to $1 \mathrm{~m}$ from the surface and $1 \mathrm{~m}$ from the bottom, in addition to other points in the profile. In 2002, the profiles were completed at 0.5-m intervals; in 2003 and 2004, a single midwater column position completed the profile. The profiling mechanism and proprietary computer on the profiling buoys proved difficult to maintain in working order over the three field seasons of the study, which resulted in numerous gaps in the profiling data. When possible, a fixedposition monitor was placed at $1 \mathrm{~m}$ off the bottom at the site of a nonfunctioning profiling buoy; as a result, the 1-m offbottom dataset at each of the buoy sites is more complete than the dataset of water column profiles. The more complete 1-m off-bottom dataset was used in computations where the data were combined with data from the rest of the network.

\section{Meteorological Data}

Both profiling buoys were equipped with a wind compass and anemometer. One was additionally equipped with air temperature and relative humidity sensors. Because the locations of the profiling buoys changed from year to year, wind speed and direction was collected at site UKL07 in all 3 years, and at site UKL08 in 2002, site UKL13 in 2003, and at site UKL16 in 2004. Air temperature and relative humidity were collected at site UKL08 in 2002, site UKL07 in 2003, and at site UKL16 in 2004. Quality assurance of wind speed and relative humidity relied on factory calibrations of the equipment; air temperature was checked with a National Institute of Standards and Technology thermometer in the field. Wind direction was checked at the site using a handheld compass.

The same equipment problems that hindered the collection of complete water-quality profile data affected the collection of the meteorological data as well, so there were numerous data gaps, particularly in 2002 (68 and 24 percent of days were missing at sites UKL07 and UKL08, respectively, between June 15 and October 15). Fortunately, the locations of the buoys in 2002 were such that the wind data collected at sites UKL07 and UKL08 were highly correlated, and could be used interchangeably for most purposes. Data collected at sites UKL07 and UKL13 in 2003 were slightly less correlated and the data collected at sites UKL07 and UKL16 in 2004 were only moderately correlated, but the wind datasets were more complete in those years (10 percent of days were missing at site UKL07 between June 15 and October 15 in 2003, and 15 percent in 2004).

\section{Nutrients and Chlorophyll a}

Water samples were collected for the analysis of dissolved nutrients (ammonia, orthophosphate, and nitrate/ nitrite), total phosphorus and chlorophyll $a$ on a weekly basis. In 2002, samples were collected at sites UKL05, UKL06, UKL07, and UKL08. In 2003, samples were collected at sites UKL05, UKL07, and UKL08, but not at site UKL06. In 2004, a fourth site was added at UKL02 (fig. 1).

Overall, 27 percent of the dissolved nutrient samples and 30 percent of the total phosphorus samples collected were for quality-assurance purposes, and included equipment blanks (first sample collected every week), splits and method replicates (each type every other week), spikes (from one to three times per season), and a few sequential blanks that were designed to test particular procedures during the course of the season. Equipment and sequential blanks are samples of inorganic blank water collected in the field using the same methods and equipment as environmental samples. Sequential blanks are a series of blank samples that pass through distinct parts of the collection process. Blank samples determine if the processes of collection, handling, transport and analysis provide measurable contamination. Split samples are environmental water samples collected once and divided into two. Replicate samples are environmental samples collected twice in rapid succession at the same site. Split samples determine the variability of sample processing and preservation, whereas replicate samples determine both the variability of the system and the variability of processing and preservation. The results of the qualityassurance sampling indicated that precision and accuracy generally were acceptable and the variability in sampling and 
processing is lower than seasonal variability (Appendix A, tables A1-A4, fig. A1). The only area of concern was ammonia in equipment blanks, which showed many instances of detectable concentration, in some cases quite high in 2003 and 2004 (table A1). This problem did not occur in 2002, when the samples for dissolved nutrients were collected into evacuated bottles, even though a VanDorn sampler was used to collect the water from depth as in the other years. The difference in the sampling process between years suggests that the samples were contaminated by air deposition. A series of sequential blanks targeted at finding the cause of the problem was analyzed in those years, but the source of the contamination was never satisfactorily pinpointed, although a small amount of contamination seemed to come from the filters. The results of equipment blanks may overestimate the amount of contamination present in an environmental sample because the equipment is flushed with native water before an environmental sample is collected, thereby rinsing any contaminants. Nonetheless, it should be assumed that contamination of the ammonia samples on the order of $10 \mu \mathrm{g} / \mathrm{L}$ is possible. Although the lowest ammonia concentrations may not be as reliable in 2003 and 2004 as in 2002, the highest ammonia concentrations are reliable and important because ammonia at these concentrations has implications for fish health. In 2005, capsule filters were used to collect the samples to be analyzed for ammonia. The use of these filters does not eliminate all contact between the sample and sample bottle and the atmosphere, but it does limit this contact. Results indicate that the problem was not eliminated entirely but was much reduced by the use of these filters.

Field processing and equipment cleaning protocols were designed to procure samples in which concentrations at a parts per billion level of concentration could be detected (U.S. Geological Survey, variously dated; Horowitz and others, 1994). Samples collected for dissolved nutrients were collected with a VanDorn sampler at two locations in the water column-in the middle of the upper one-half of the water column (one-quarter of the water column depth), and in the middle of the lower one-half of the water column (three-quarters of the water column depth) and passed through a $0.45-\mu \mathrm{m}$ filter. Samples were chilled and shipped within 24 hours to the National Water Quality Laboratory (NWQL) in Denver, Colorado. In 2002 only, samples for dissolved nutrients were collected into an evacuated container to minimize any loss of ammonia from a high $\mathrm{pH}$ sample (C.J. Patterson, U.S. Geological Survey, written commun., 2002). In 2002 and 2003, samples for total phosphorus and chlorophyll $a$ were integrated over the water column by collecting water in a large-diameter flexible hose from the surface to $0.5 \mathrm{~m}$ from the bottom. In 2004, the flexible hose was replaced with a cage sampler that was lowered with sample collection bottles at a constant rate to $0.5 \mathrm{~m}$ from the bottom. This cage sampler proved easier to use, and the quality-assurance data did not indicate a significant change in the median difference between replicate samples of total phosphorus from 2003 to 2004 [although the median difference between replicates in chlorophyll $a$ increased from 2003 to 2004, but remained within acceptable limits (table A3)]. In all years multiple subsamples as needed from either the VanDorn sampler or the hose/cage sampler were composited with a churn splitter, from which splits for different analyses were drawn. Total phosphorus samples were acidified, chilled, and shipped within 24 hours to the NWQL. Finalized data are stored in the USGS National Water Information System (NWIS) database (accessible through NWISWeb, http://waterdata.usgs.gov/or/nwis/qw).

Samples for the analysis of chlorophyll $a$ were sent to Aquatic Analysts in White Salmon, Washington. The chlorophyll $a$ sampling program was designed to measure this surrogate for algal biomass in a cost-effective way, with good precision, and allow a reliable assessment of relative changes in algal biomass. The results of quality-assurance sampling and other more qualitative assessments of the dataset indicate that the chlorophyll $a$ dataset is well-suited to this purpose. Over the 3 years of the study, 20 method replicates were collected ( 7 percent of the total samples) and the median percentage of the difference between the replicates was 4, 11, and 11 percent in 2002, 2003, and 2004, respectively; 26 split samples were collected (10 percent of the total samples) and the median percentage of the difference between the splits was 3,7 , and 10 percent in 2002, 2003, and 2004, respectively. The difference between replicate and split samples is low and shows that the variability due to collection and analysis methods is small compared to the overall temporal variability of the data (Appendix A, fig. A1). Chlorophyll $a$ was determined fluorometrically for this study. The quantitative comparability between this method and the high performance liquid chromatography method used by the NWQL to determine chlorophyll $a$ in samples prior to October 1, 2005, has not been established, and the chlorophyll $a$ data collected during this study are not stored in the USGS NWIS database. Chlorophyll $a$ data collected by the Klamath Tribes in their biweekly sampling program were analyzed by a spectrophotometric method; therefore the chlorophyll $a$ data collected during this study should not be assumed to be quantitatively comparable to that dataset either.

\section{Statistical Methods}

Nonparametric statistics were used in this report in order to accommodate data that are not normally distributed. When correlations between datasets were calculated, Spearman rather than Pearson correlations were used. When analysis of variance (ANOVA) was used, the test used was the Tukey studentized range test for differences in the means, performed on the rank-transformed data. All statistical tests were run using SAS System for Windows ${ }^{\mathrm{TM}}$, Release 8.02, SAS Institute Inc., Cary, North Carolina. 


\section{Physical Description of Upper Klamath Lake}

Upper Klamath Lake is shallow-92 percent of the area of the lake is less than $4 \mathrm{~m}$ in depth, 65 percent is less than $3 \mathrm{~m}$, and 20 percent is less than $2 \mathrm{~m}$. The 4 percent of the area of the lake that is greater than $5 \mathrm{~m}$ depth is found in a narrow trench along the lake's western shore (fig. 1). The southernmost extent of this trench is at roughly the latitude of Buck Island; it runs across the entrance to Howard Bay, along the western shoreline and then parallel to Eagle Ridge to the west of Bare Island. At the tip of Eagle Ridge, the trench turns west and runs across the entrance of both Shoalwater and Ball Bays before turning north again and gradually fading away. Maximum depths in this trench approach $15 \mathrm{~m}$. The bathymetry of the lake plays a prominent role in defining the wind-driven circulation and has consequences for water quality as well.

Within the northern one-third of the lake that constitutes the study area, there are less extreme variations in the bathymetry that can influence observations at the continuous monitors. The deepest part of the study area (excluding the trench) is to the south and west, up against Pelican Bay to the west and Shoalwater and Ball Bays to the south. The lake bottom shoals upward from there to the north and east, so much so that site UKL01 could not be maintained for the entire field season as the lake level declined. To provide a quantitative measure of the difference in depth across the study area, the depths at sites UKL10, UKL07, and UKL02 were 3.8, 4.5, and $2.9 \mathrm{~m}$, respectively, on June 1, 2003.

Being a shallow lake, Upper Klamath Lake does not develop a strong thermocline as would be observed in much deeper lakes. Nonetheless, some degree of thermal stability can, and often does, develop in areas of Upper Klamath Lake that are deeper than about $2.5 \mathrm{~m}$. This thermal stability is most resistant to mixing in the trench, but it routinely develops and erodes over the course of a day in areas of the lake only 2.5-3 m deep. During 2002, data from $1 \mathrm{~m}$ off the bottom and $1 \mathrm{~m}$ from the surface were collected with profiling buoys at sites UKL07 and UKL08 (fig. 2). The buoy at site UKL07 remained there during all 3 years of the study, but in 2003, the second buoy was moved to site UKL13 (fig. 3), and in 2004, it was moved to site UKL16 (fig. 4). The depth at site UKL07 varied by almost a meter between the 3 years, but was comparable to site UKL08 in 2002 and to site UKL13 in 2003. In 2004, the depth at site UKL16 was much greater than that at site UKL07 (table 1).

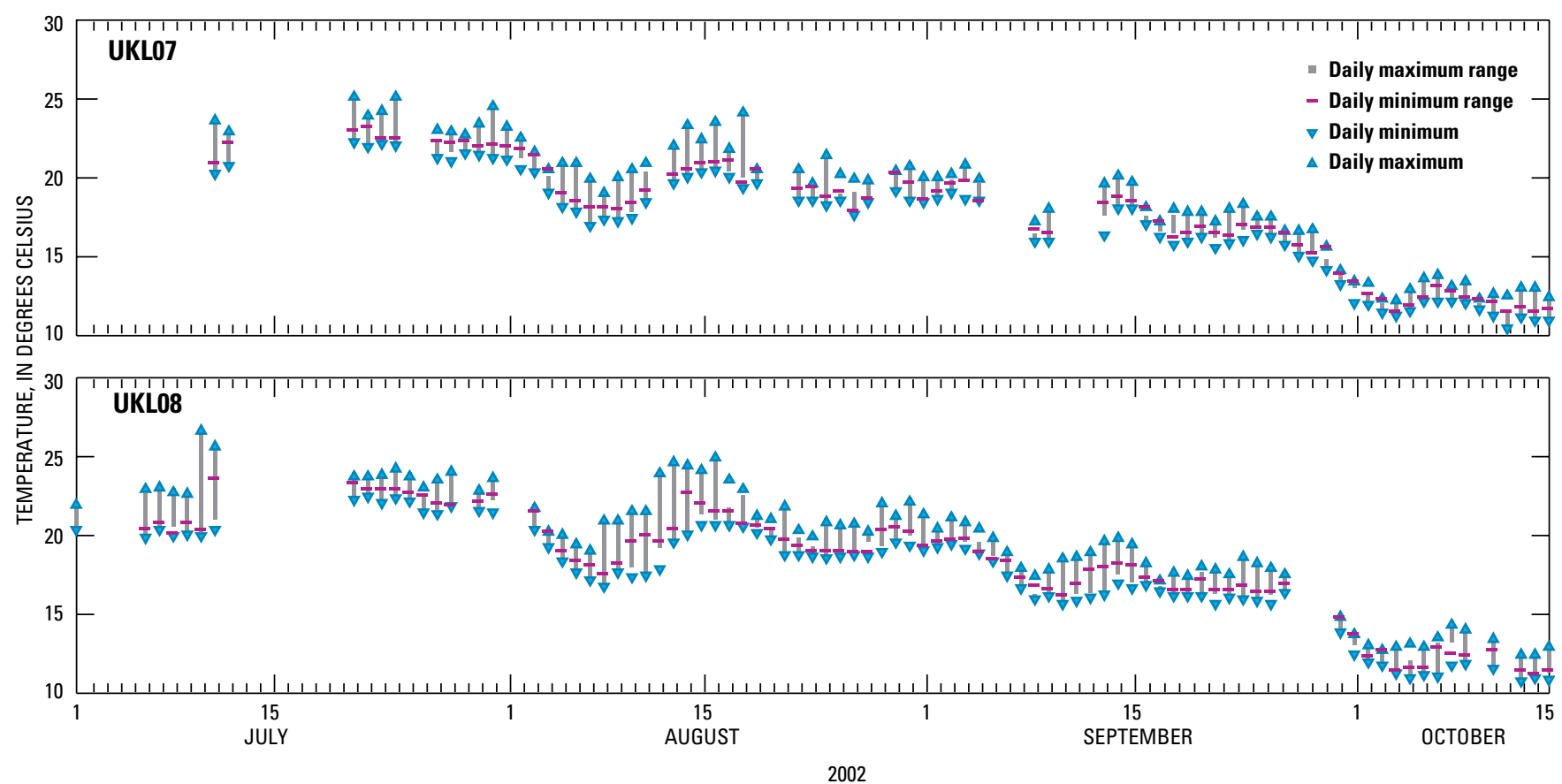

Figure 2. Daily maximum range in temperature over the water column, minimum range in temperature over the water column, maximum temperature, and minimum temperature, from hourly values collected at 1 meter off the bottom and 1 meter from the surface at sites UKL07 and UKL08 in Upper Klamath Lake, Oregon, 2002. 


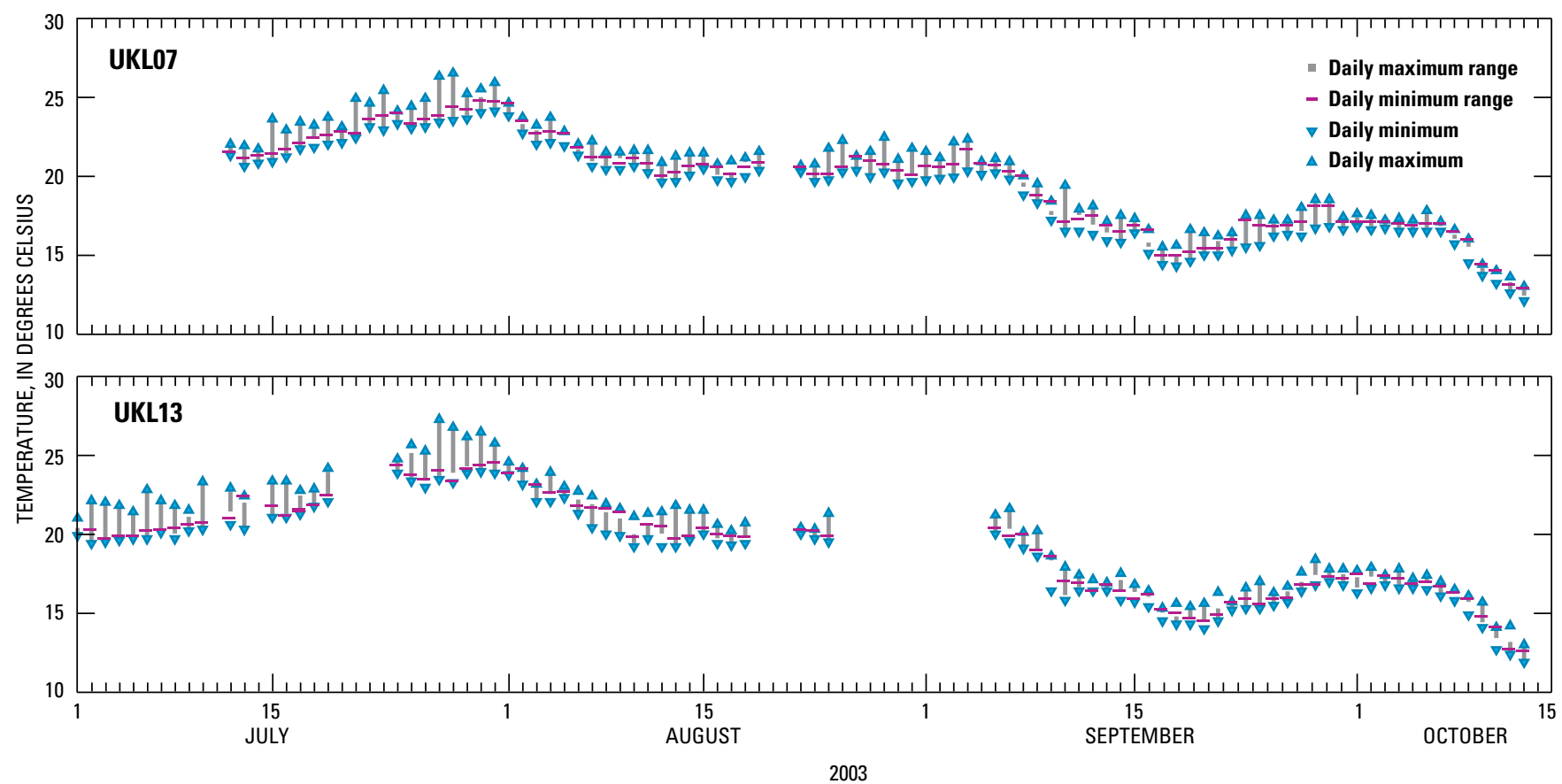

Figure 3. Daily maximum range in temperature over the water column, minimum range in temperature over the water column, maximum temperature, and minimum temperature, from hourly values collected at 1 meter off the bottom and 1 meter from the surface at sites UKL07 and UKL13 in Upper Klamath Lake, Oregon, 2003.

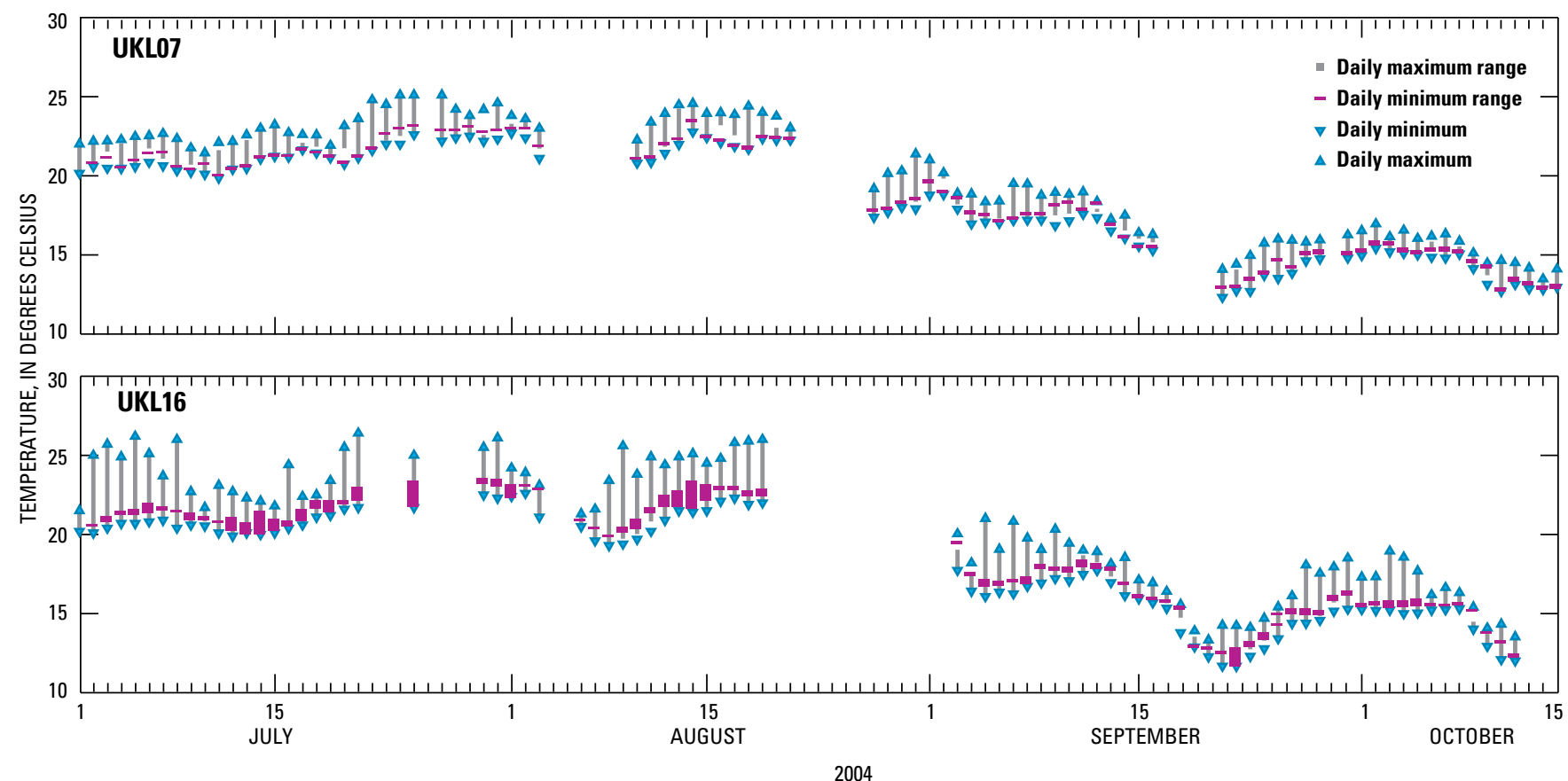

Figure 4. Daily maximum range in temperature over the water column, minimum range in temperature over the water column, maximum temperature, and minimum temperature, from hourly values collected at 1 meter off the bottom and 1 meter from the surface at sites UKL07 and UKL16 in Upper Klamath Lake, Oregon, 2004. 
Table 1. Water column depths at the beginning of the summer months at sites where profiling buoys were located, Upper Klamath Lake, Oregon, 2002-04.

[Symbols: $<$, less than]

\begin{tabular}{ccccc}
\hline \multirow{2}{*}{ Site } & \multirow{3}{*}{ Year } & \multicolumn{3}{c}{$\begin{array}{c}\text { Depth at the beginning of the month } \\
\text { (meters) }\end{array}$} \\
\cline { 3 - 5 } & & July & August & September \\
\hline UKL07 & 2002 & 3.0 & 2.8 & 2.3 \\
& 2003 & 3.9 & 3.5 & 3.3 \\
& 2004 & 3.7 & 3.3 & 3.1 \\
UKL08 & 2002 & 3.2 & 3.0 & 2.5 \\
UKL13 & 2003 & 3.9 & 3.5 & 3.3 \\
UKL16 & 2004 & 14 & $<14$ & $<14$ \\
\hline
\end{tabular}

Data from the profiling buoys show that a maximum daily difference in temperature of $1-3^{\circ} \mathrm{C}$ between $1 \mathrm{~m}$ off the bottom and $1 \mathrm{~m}$ from the surface is common and, in fact, this amount of thermal stability develops nearly every day during the summer. These data also show that the daily minimum difference in temperature between $1 \mathrm{~m}$ off the bottom and $1 \mathrm{~m}$ from the surface is usually zero (depicted by a thin red line in the figures) - that nearly every day the stratification that develops is eroded at some point either by wind mixing or cooling at the surface or both. Wind speed typically picks up in the late morning to early afternoon, reaching a maximum in the evening and then dying down in the early morning hours, with calm conditions persisting through the morning. Thermal stability typically develops and increases throughout the morning and afternoon, and then collapses in the evening or early morning. Occasionally a period of calm winds will result in stratification persisting for several days, particularly at deeper sites such as UKL16, which is located in the trench (fig. 4). This daily pattern of thermal stability provides ideal conditions for the growth of AFA, which is able to take advantage of thermal stability to regulate buoyancy in order to position cells optimally in the water column (Oliver and Ganf, 2000). Thus, the typical pattern of diurnal stratification/ destratification in the lake probably has contributed to the ability of AFA to out-compete green algal species in the lake.

The depth of the photic zone varies with the amount of AFA in the water column, but typically is between 1.5 and $2.5 \mathrm{~m}$ during a moderate to heavy bloom (fig. 5). Consequently, much of the lake is shallow enough that nearly the entire water column is continuously within the photic zone. The areas this shallow include Howard Bay and the open waters of the lake east of Howard Bay and south to the lake outlet, as well as the northern and easternmost parts of the study area, including south of Agency Straits and the entrance to the Williamson River.
Because observations of water quality, meteorological variables, and currents were made simultaneously in this study, an increased understanding of the wind-driven circulation in the lake has emerged. Two acoustic Doppler current profilers (ADCPs) were placed to the east (ADCP8) and west (ADCP4) of Bare Island in 2003 by investigators at the USGS National Research Program. A basic description of ADCP operation and the type of data they collect is provided by Gartner and Ganju (2002). During prevailing wind conditions (wind from the west to northwest, between about 270 and 300 degrees), currents at the trench site (ADCP4) were consistently aligned toward about 350 degrees, just west of due north, while currents to the east of Bare Island were consistently aligned to between 120 and 150 degrees, to the southeast (fig. 6). There were periods of time lasting from one to several days when the wind reversed and came from the east to southeast. These periods are seen in the ADCP data as times when the currents also reversed direction.

In 2004, an ADCP was put in the midtrench area at ADCP1 from June 16 through August 6, and then it was moved to ADCP4 for the next deployment from August 6 to September 15 (fig. 7). A second ADCP was put in at ADCP2 from June 16 through August 6, and then moved to ADCP3 from August 6 to September 15. The currents at both sites in the trench were aligned with the bathymetry in the trench, flowing north under prevailing (west to northwest) wind conditions, but reversing direction for periods from one to a few days when the wind direction changed. Currents at site ADCP2 were low and highly variable in direction, flowing primarily to the south and southeast, occasionally turning northward briefly during a particularly strong wind reversal. Currents at ADCP3 were consistently northward, aligned with the end of the trench as it turns northward at Ball Bay. There were no strong wind reversals during the period of record at $\mathrm{ADCP} 3$, so it is unclear whether the currents there are likely to reverse when the wind changes direction.

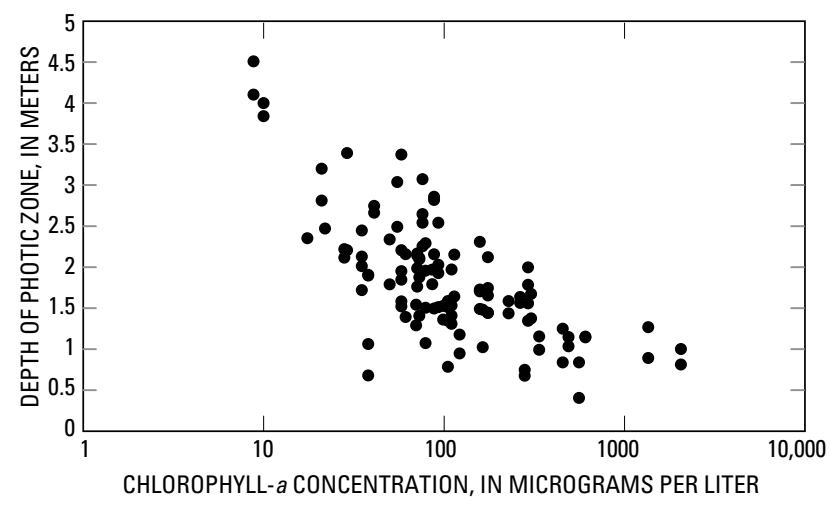

Figure 5. Depth of the photic zone (the depth where light is 1 percent of surface value), as a function of chlorophyll a concentration in Upper Klamath Lake, Oregon. 
The response of the lake to wind stress under prevailing wind conditions (winds from the west to northwest) is illustrated conceptually in figure 8. Under these conditions, the currents over the broad, shallow part of the lake to the east of Bare Island flow down the lake to the southeast. Strong currents flowing northwest carry a return flow in the narrow trench area to the west of Bare Island. Circulation in the study area is clockwise under prevailing wind conditions. Preliminary modeling has indicated that most of the water in the lake turns around in the southern part of the lake between Howard Bay and Buck Island, but this part of the circulation is complicated and will require further study to refine (R.T. Cheng, U.S. Geological Survey, unpub. data, 2004). It is clear, however, that the pattern of a broad flow to the southeast on the eastern side of the lake and a narrow flow to the northwest through the trench on the western side of the lake is a persistent feature. When the wind reverses, the basic flow pattern reverses as well, to a broad flow to the northwest on the east of Bare Island, narrow flow to the southeast in the trench, and a counterclockwise circulation through the study area. The basic principles of the flow pattern were suggested in earlier modeling work (Blank and Juza, 2001), but the data to confirm and refine the results were not available until the placement of the ADCPs in the lake during this study.
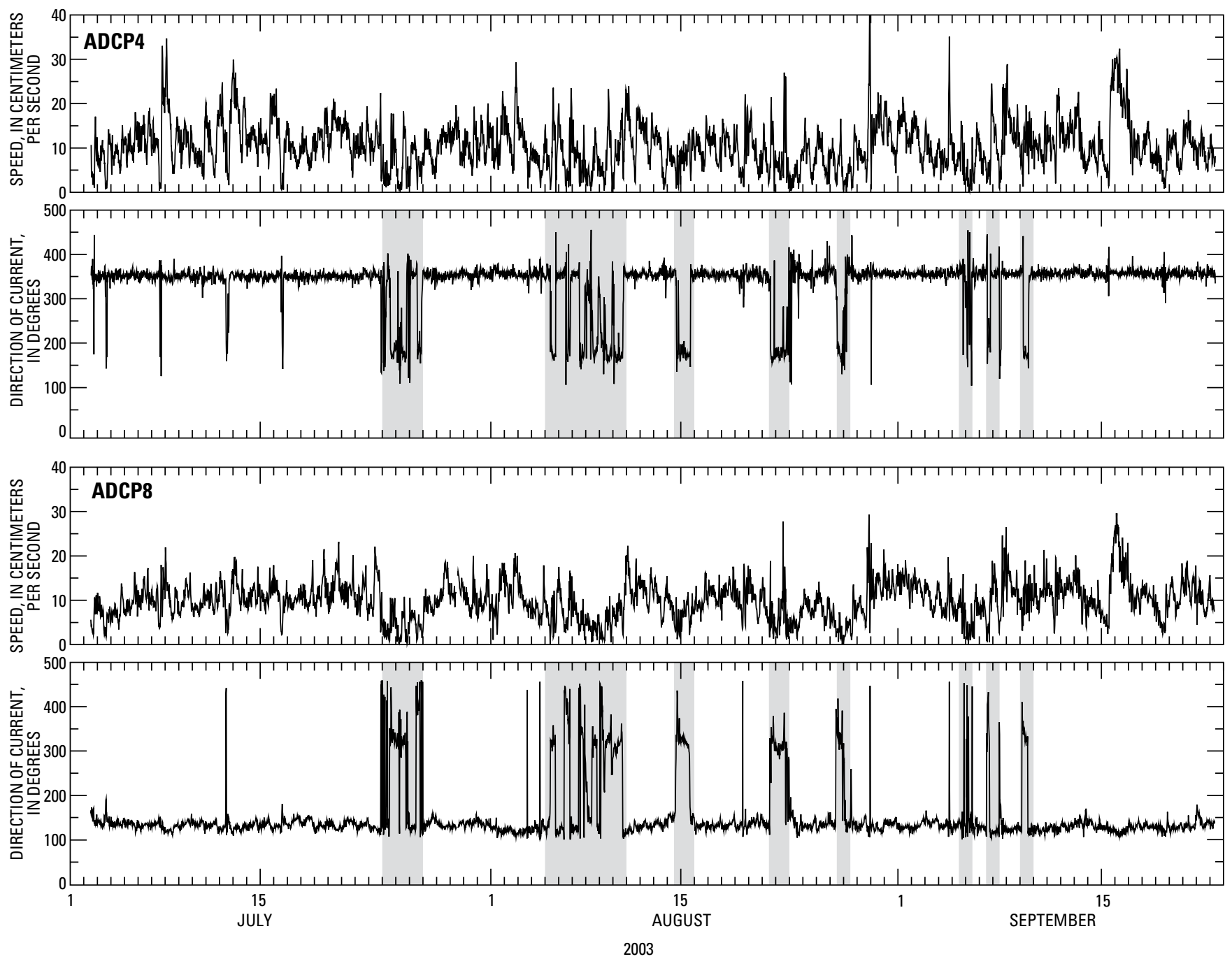

Figure 6. Half-hourly current speed and direction recorded at sites ADCP4 and ADCP8, Upper Klamath Lake, Oregon, 2003. Shaded time periods denote times of wind and current reversals. The current direction data range from 100 to 460 degrees because 360 degrees have been added to values of current direction less than 100 degrees to avoid the appearance of a large shift when the wind direction varies to either side of north. 

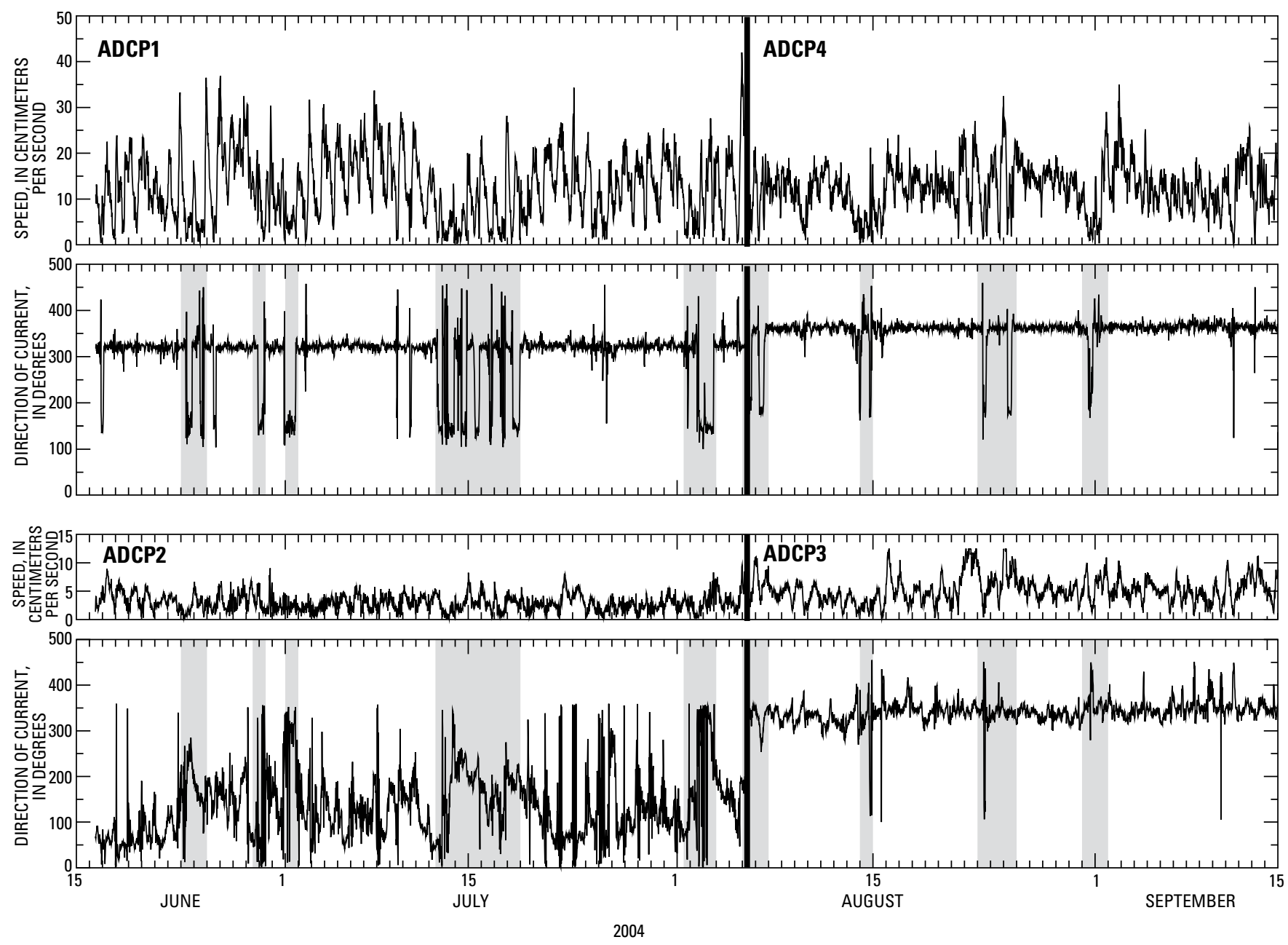

Figure 7. Half-hourly current speed and direction recorded at sites ADCP1 and ADCP2 (before August 6) and at sites ADCP3 and ADCP4 (after August 6), Upper Klamath Lake, Oregon, 2004. Shaded time periods denote times of wind and current reversals. The current direction data from ADCP1, ADCP3, and ADCP4 range from 100 to 460 degrees because 360 degrees have been added to values of current direction less than 100 degrees to avoid the appearance of a large shift when the wind direction varies to either side of north. 


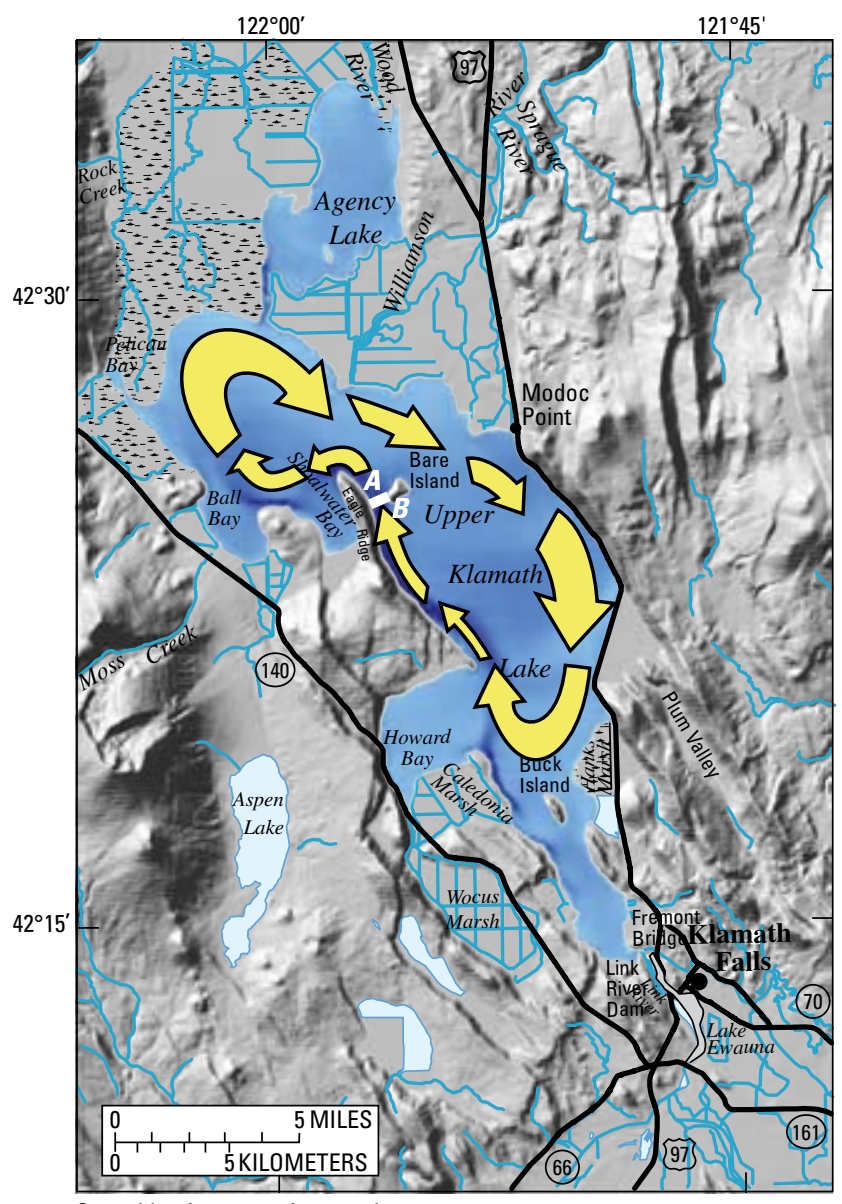

See table of contents for mapping sources

EXPLANATION

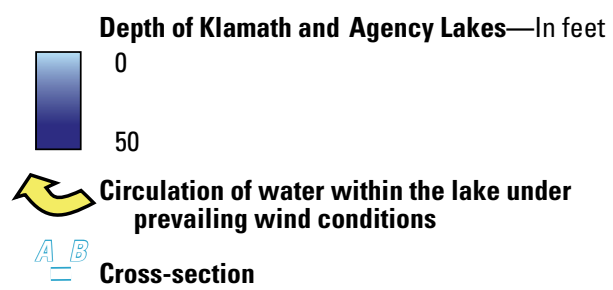

Figure 8. Circulation pattern in Upper Klamath Lake in response to prevailing wind conditions.

An instantaneous measurement of the discharge northward through the trench west of Bare Island (cross-section A-B in fig. 8) obtained in June 2005 was $580 \mathrm{~m}^{3} / \mathrm{s}$ (R.E. Wellman, U.S. Geological Survey, written commun., 2005). On the basis of this value and a Geographic Information System (GIS) estimate of the volume of the lake north of Buck Island of $475 \times 10^{6} \mathrm{~m}^{3}$ (T.L. Haluska, U.S. Geological Survey, written commun., 2005), an estimate of the traveltime around the entire loop is on the order of 10 days. This is not to be confused with residence time in the lake, the amount of time between when a parcel of water enters the lake and when it leaves, which is likely to be many times longer.

\section{Water-Quality Observations}

\section{Weekly Nutrients and Chlorophyll a}

The weekly water samples, while collected at only a subset of the sites in the study area, provide valuable context for understanding the data from the continuous water-quality monitors. Trends and fluctuations in water-quality parameters often are associated with bloom dynamics, as reflected in the chlorophyll $a$ data. The basic reasons are straightforward: a sharp reduction in chlorophyll $a$ indicates a crash in the bloom. The spatial extent of the crash may be small enough to be captured at only one site, or it may be large enough that the crash is evident at several sites. A crash in the bloom is characterized by a shutdown or sharp reduction in oxygen production through photosynthesis, which is manifested as a decrease in dissolved oxygen, generally to values below saturation as ongoing sediment and water column demands continue to operate unabated. Periods of growth in the bloom are, in contrast, generally manifested as supersaturated dissolved oxygen and high $\mathrm{pH}$, as photosynthesizing algae consume carbon dioxide and produce oxygen.

The chlorophyll $a$ data collected in all 3 study years are presented in figure 9 . These 3 years present interesting contrasts and demonstrate that the 3 study years were quite different. In 2002, the chlorophyll $a$ in samples collected at three of the four weekly sampled sites indicated that a crash in the bloom occurred around mid-July; the chlorophyll $a$ concentration at site UKL06 decreased from $630 \mu \mathrm{g} / \mathrm{L}$ on July 15 to $29 \mu \mathrm{g} / \mathrm{L}$ on July 22 . At all sites except UKL08, chlorophyll $a$ concentration remained low for two weekly samples. The best estimate of the dates encompassing the bloom crash are June 19 to August 1, which was arrived at by projecting backward 3 days (approximately one-half of the weekly sampling interval) from the first sample date on which the crash was observed, and forward 3 days from the last sample date on which the bloom was observed. A second crash, evident on only one sample date, occurred later in the season, and the best estimate of the dates encompassing that crash are September 6-12.

The sample collected on July 29, 2002, in Shoalwater Bay was an anomaly - a value of $1,410 \mu \mathrm{g} / \mathrm{L}$ was measured there at the same time that the bloom appears to have crashed at the other sites. Such exceptionally high values have, on occasion, been measured in Shoalwater Bay and Howard Bay in the past 15 years (Klamath Tribes, unpub. data), and may be an indication that AFA can become physically concentrated in these embayments by the action of wind and currents. The high chlorophyll $a$ concentration in Shoalwater Bay when concentrations elsewhere in the lake were at a minimum also is evidence that the blooms in the embayments tend be localized, and that the bloom dynamics in the embayments are often independent of the bloom dynamics in the open waters of the lake. 
Chlorophyll $a$ in samples collected in 2003 at all three weekly sampled sites indicated that a crash in the bloom occurred near the end of July, when chlorophyll $a$ concentration decreased from $397 \mu \mathrm{g} / \mathrm{L}$ on July 15 to 17.5 $\mu \mathrm{g} / \mathrm{L}$ on July 23 . The estimated dates of the crash are July 19 to August 1 . Secondary crashes lasting only one sample date were observed in the second and fourth weeks of September; estimated dates are September 6-12 and September 20-26. There is no evidence that the fact that the dates of the July and first September crash coincide exactly with those in 2002 is anything other than a coincidence, although it is possible that some natural cycle in the bloom was responsible.

Data from 2004 provide an interesting contrast to the other 2 years. The chlorophyll $a$ data did not indicate a dramatic bloom crash at any point in the season that affected all sites, although very low chlorophyll $a$ values were measured at individual sites at various times throughout the season. On the basis of low chlorophyll $a$ concentrations at four of the five sites, a minor bloom crash may have occurred between August 7 and 13.

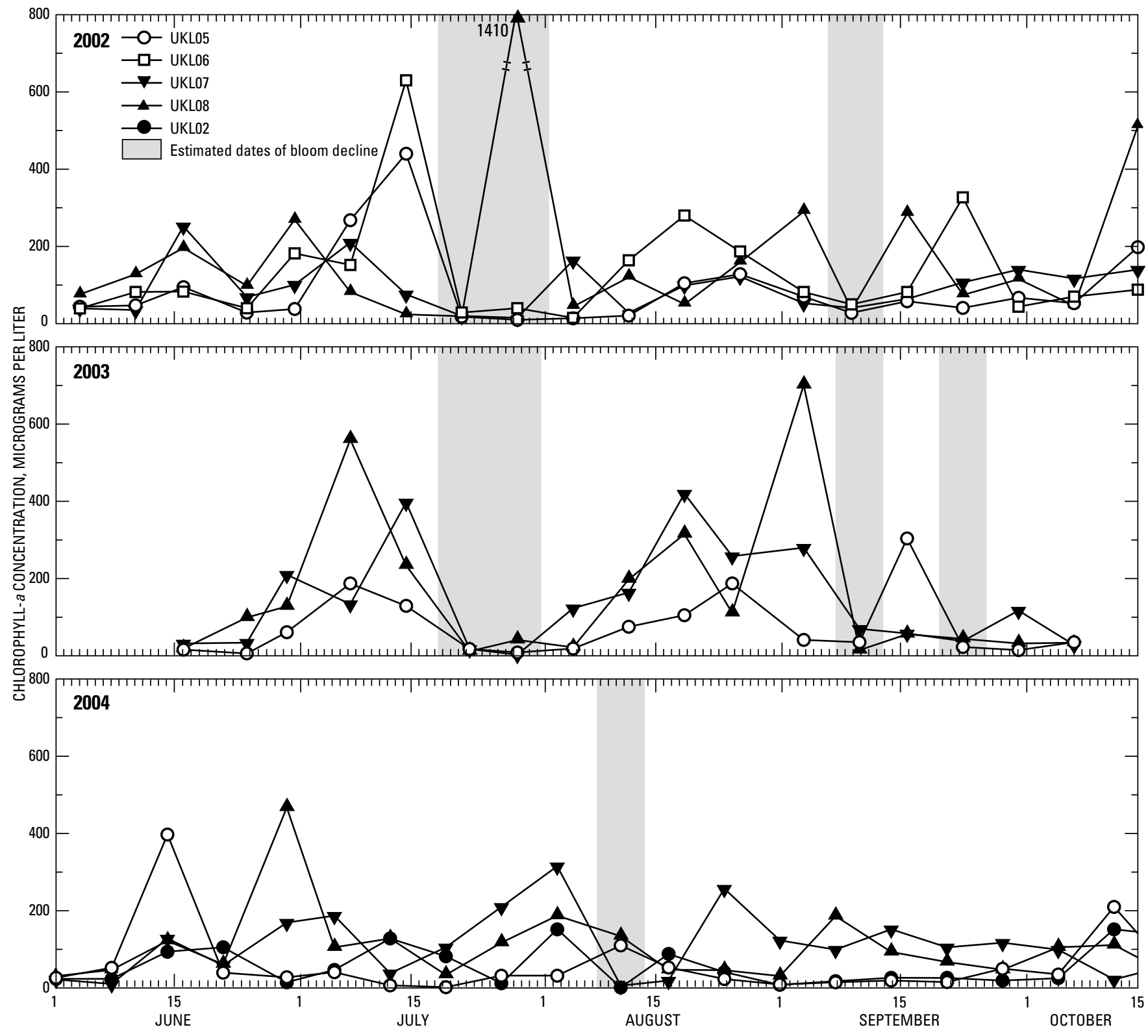

Figure 9. Chlorophyll a concentrations at sites in Upper Klamath Lake, Oregon, 2002-04. 
The crashes in the AFA blooms are not prominent in the total phosphorus data (fig. 10), indicating that when the cells senesce, they tend to recycle nutrients to the water column, rather than carrying nutrients to the lake bottom. This is also evident in the plots of dissolved nutrients (orthophosphate and ammonia), which show a roughly inverse relation overall with chlorophyll $a$ (figs. 11 and 12).

When high ammonia concentrations occur coincident with high $\mathrm{pH}$ and high temperatures, a significant fraction of the total concentration will be present in the un-ionized form, which is particularly toxic to aquatic life. The dependence on $\mathrm{pH}$ is stronger than the dependence on temperature-at $22^{\circ} \mathrm{C}$ and a $\mathrm{pH}$ of 9,31 percent of the ammonia will be in un-ionized form, but at a $\mathrm{pH}$ of 9.5 that fraction increases to 60 percent (U.S. Environmental Protection Agency, 1998). Because ammonia tends to peak when the bloom declines, the peaks in ammonia are often mismatched in time with the highest $\mathrm{pH}$ values. That is why the peak in un-ionized ammonia preceded the peak in total ammonia concentration at most sites in the 3 study years (fig. 13). The highest concentration of un-ionized

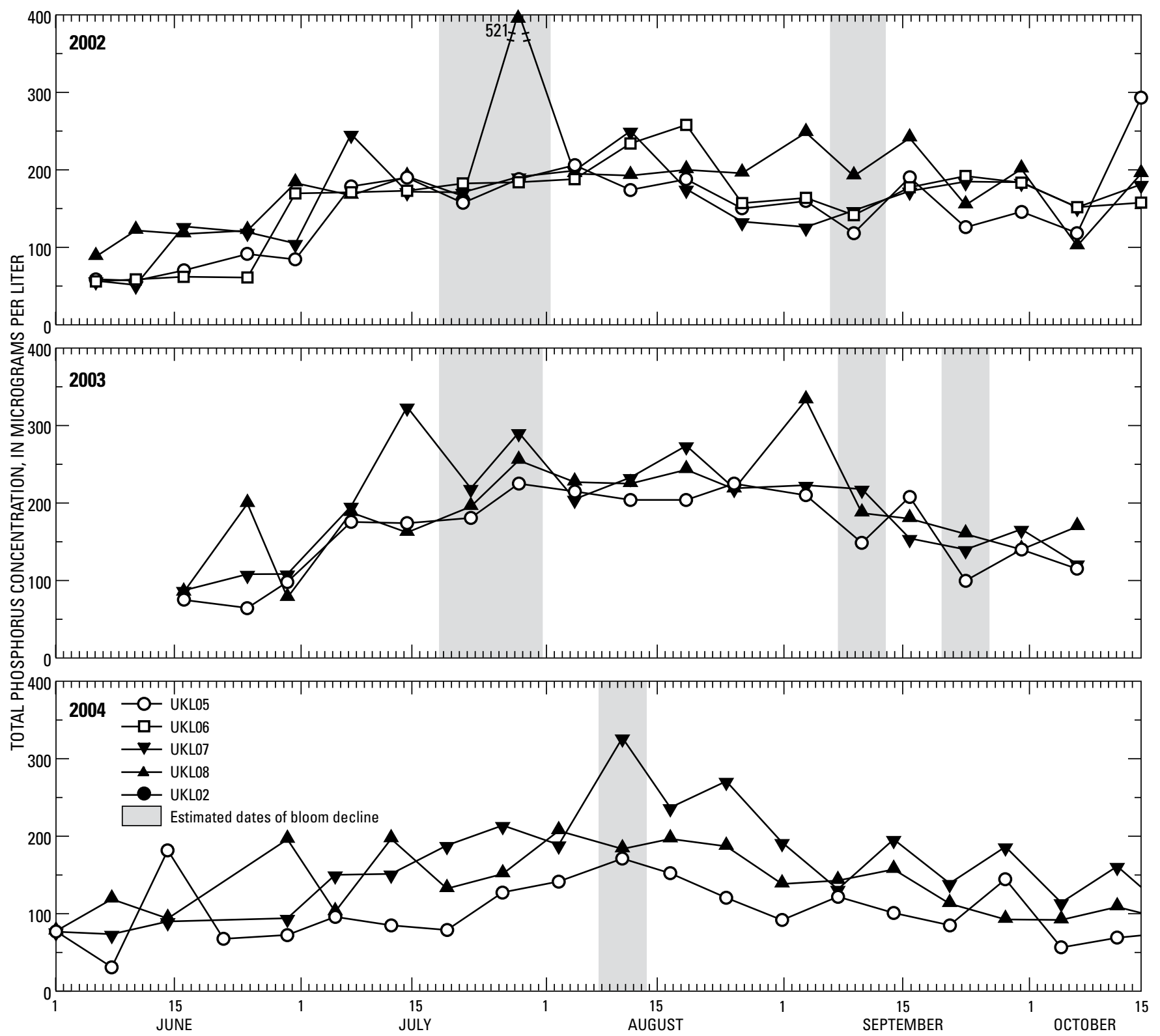

Figure 10. Total phosphorus concentrations at sites in Upper Klamath Lake, Oregon, 2002-04. 


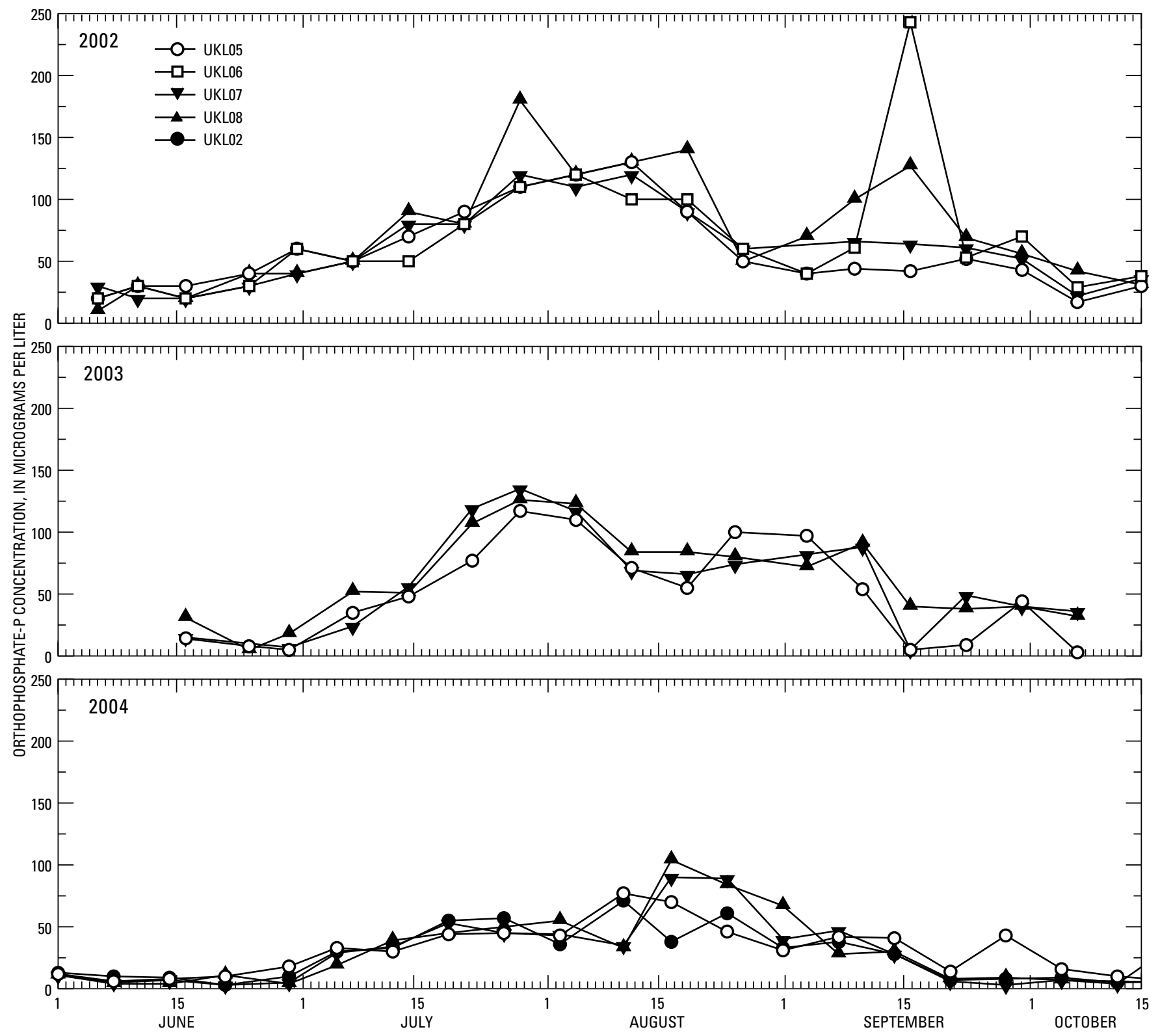

Figure 11. Orthophosphate-P concentrations at sites in Upper Klamath Lake, Oregon, 2002-04. 


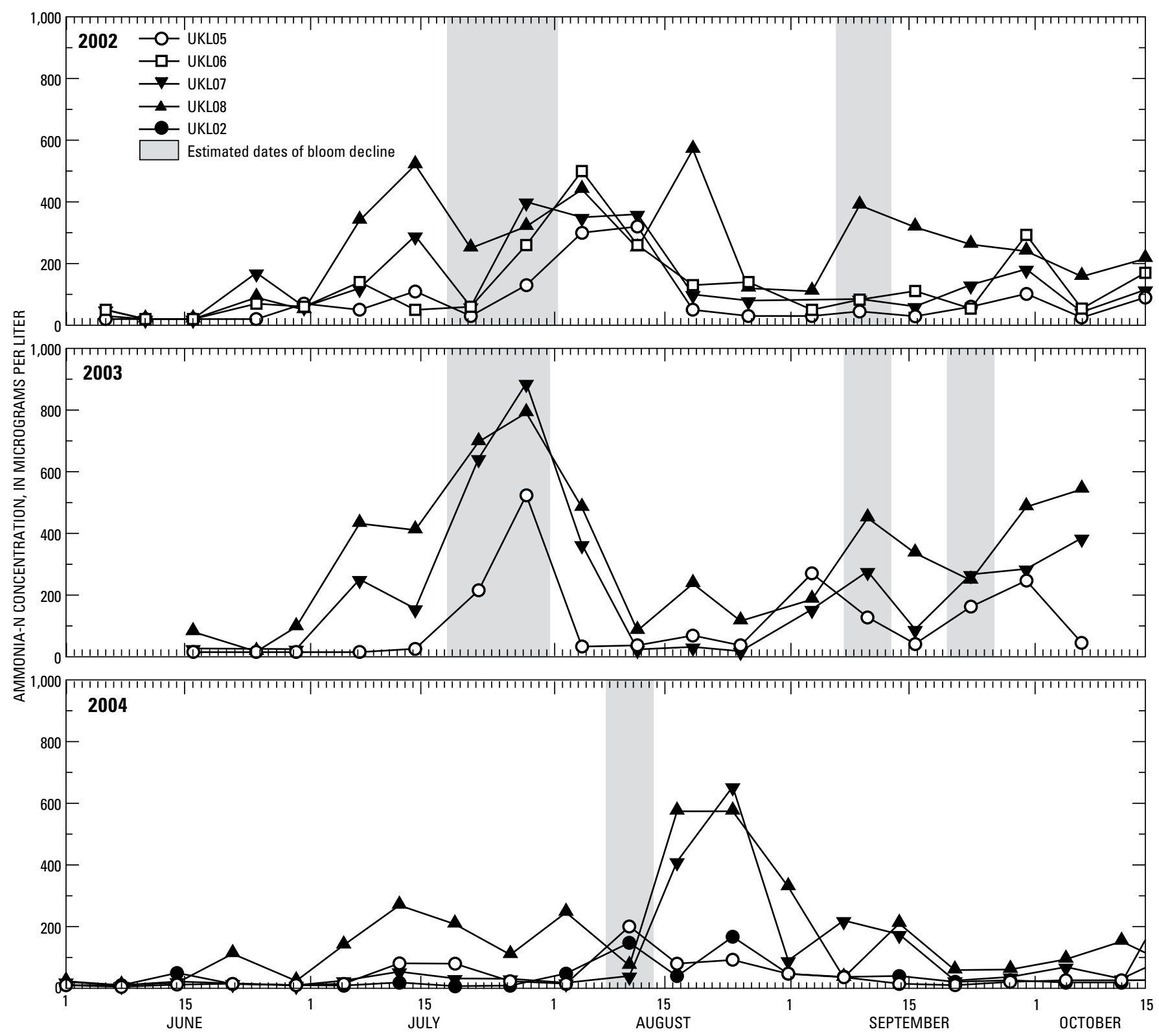

Figure 12. Ammonia-N concentrations at sites in Upper Klamath Lake, Oregon, 2002-04. 
ammonia occurred in 2003 just prior to the bloom crash at the end of July. Concentrations peaked at nearly $300 \mu \mathrm{g} / \mathrm{L}$ at two sites. Experimentally derived 96-hr LC $_{50}$ (median lethal concentration) values for un-ionized ammonia were 780 and $530 \mu \mathrm{g} / \mathrm{L}$ for Lost River and shortnose suckers, respectively (Saiki and others, 1999), well above the peak concentrations observed in this study. Nonetheless, exposure to lower concentrations cannot be dismissed as a source of chronic stress to fish.
The lack of detectable nitrate/nitrite concentrations through much of 2002 and 2003 and very low nitrate/ nitrite concentrations overall in comparison to ammonia, suggest that, in spite of very high ammonia concentrations, nitrification is not a rapid or effective process for removal of ammonia from the water column (fig. 14).

In addition to the temporal patterns through the June to October season, the chlorophyll $a$ and nutrient data showed site-specific trends (fig. 15). The median chlorophyll $a$ and

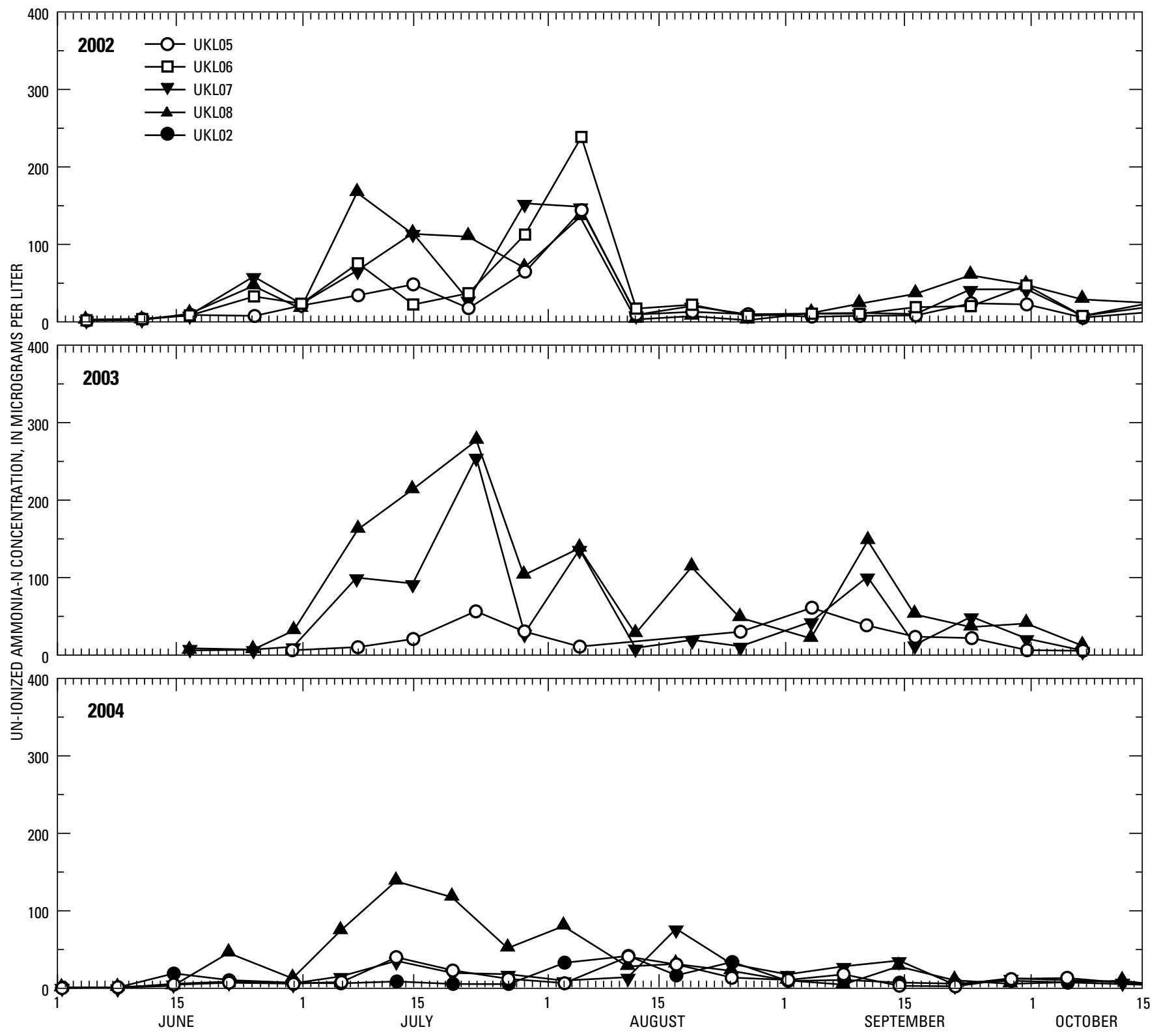

Figure 13. Un-ionized ammonia-N concentrations at sites in Upper Klamath Lake, Oregon, 2002-04. 
total phosphorus values were higher at site UKL07 in all 3 years than at sites UKL05, UKL02 (2004 only), or UKL06 (2002 only). Thus, there is a tendency for the deeper part of the study area to the south to experience higher concentrations of chlorophyll $a$, total phosphorus, and ammonia than the shallower part of the study area to the north and northeast. There also is a slight tendency for concentrations at site UKL08, which is in Shoalwater Bay, to be lower than those at site UKL07, which is centrally located in the study area.

\section{Continuous Water-Quality Monitors}

In order to provide a sense of the overall seasonal and interannual variability in water quality in the study area, it was useful to consolidate the datasets into a single statistical median that would be broadly representative of the entire study area. Because the sampling design changed between 2002 and 2003, this median was computed using only sites that were common (or nearly so) to all 3 years: UKL01-

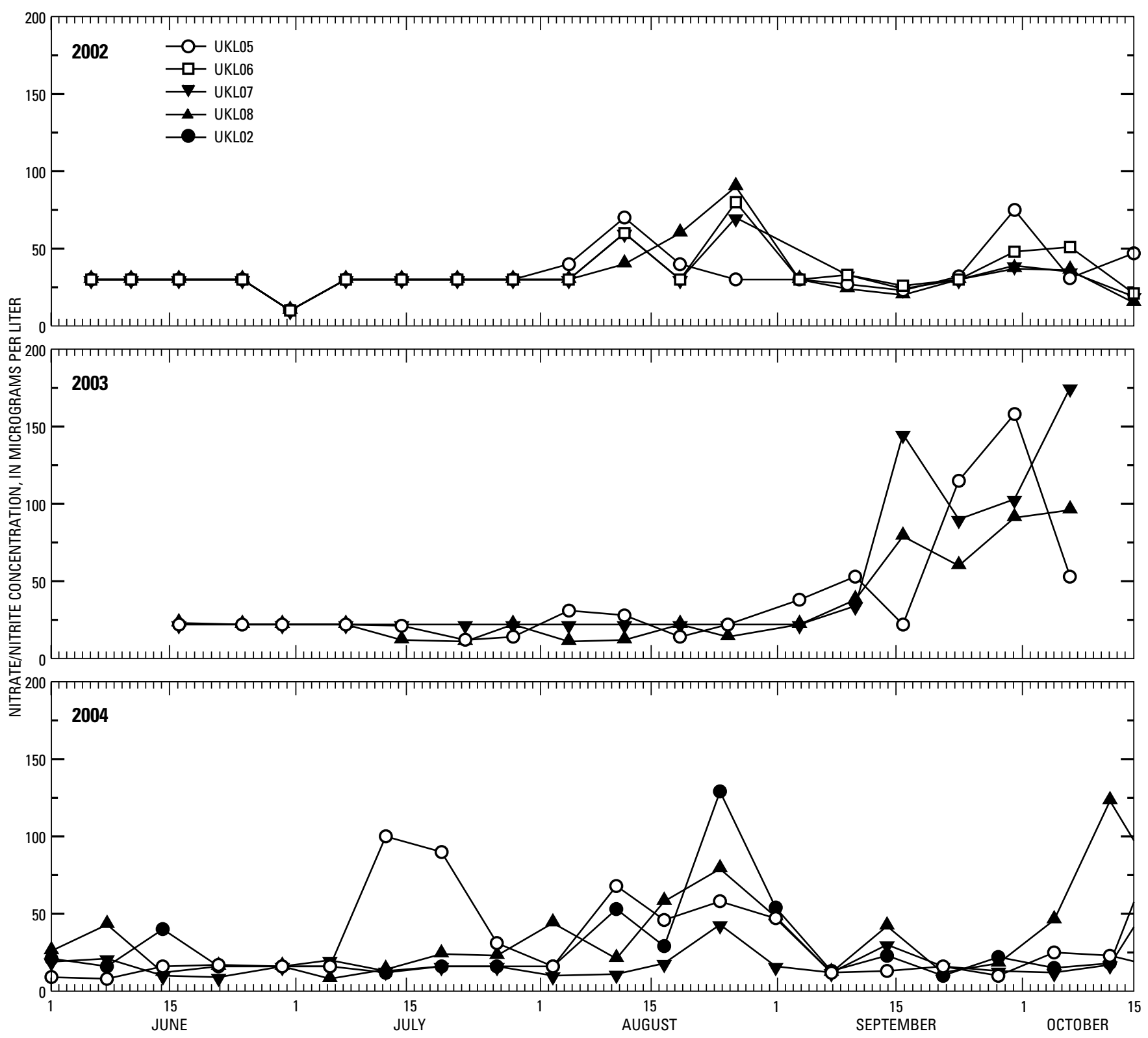

Figure 14. Nitrate/nitrite-N concentrations at sites in Upper Klamath Lake, Oregon, 2002-04. 

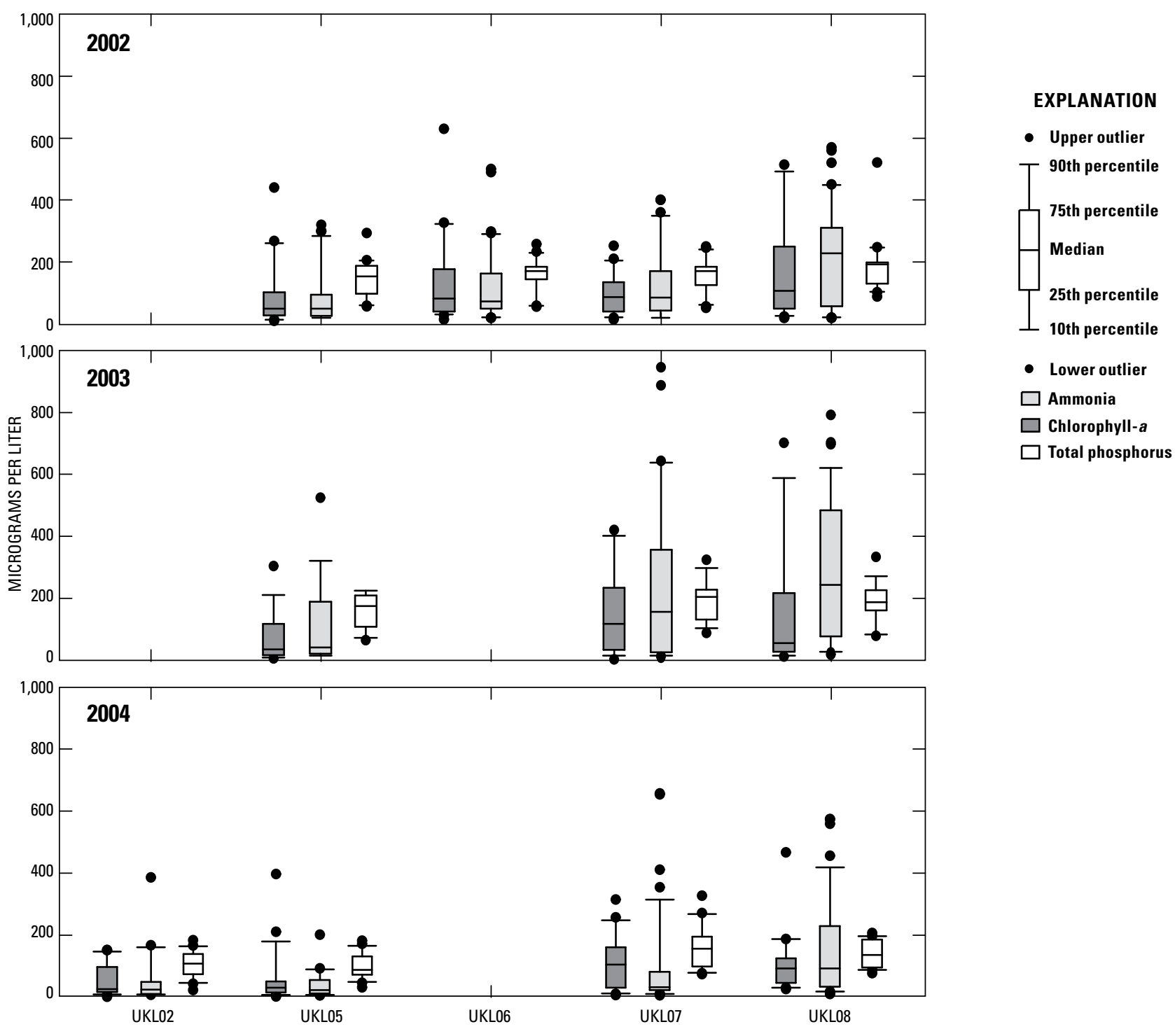

Figure 15. Statistical distributions of chlorophyll $a$, total phosphorus, and ammonia-N concentrations for the entire field season at individual sites in Upper Klamath Lake, Oregon, 2002-04.

UKL11. Two sites, UKL07 and UKL08, were located at the same latitude and longitude in all 3 years; the rest of the sites included in the median were located at a different latitude and longitude between 2002 and 2003, but were judged to represent generally similar locations in the lake. A study-area daily median was only computed when a daily median could be computed for 8 of the 11 individual sites. Daily medians were calculated at a site only for those days on which at least 20 hours of data were available.

The study-area daily median of dissolved oxygen, percent saturation of dissolved oxygen, temperature, and $\mathrm{pH}$ for 2002-04 is presented in figure 16. The percent saturation of dissolved oxygen provides a convenient way to assess the seasonal trends in each year and to make yearto-year comparisons. A value of 100 percent saturation indicates that the water column is in equilibrium with the atmosphere. Values greater than 100 percent indicate that oxygen production through photosynthesis is in excess of oxygen consumption through respiration and decay processes. Values less than 100 percent saturation indicate the opposite situation-oxygen consumption is in excess of oxygen production. Surface exchange processes always act to move the system toward 100 percent saturation from either a supersaturated or an undersaturated condition.

Over much of the summer and autumn in all 3 years the rate of photosynthetic production of oxygen in the water was enough to keep the study-area daily median dissolved oxygen concentrations well above saturation, even though chlorophyll $a$ concentrations indicate that the bloom was highly variable, both spatially and temporally. This was the case even though concurrent oxygen demanding processes such as sediment oxygen demand and water column biological oxygen demand can consume large amounts of oxygen (Wood, 2001; Lieberman and others, 2003). In each year, 

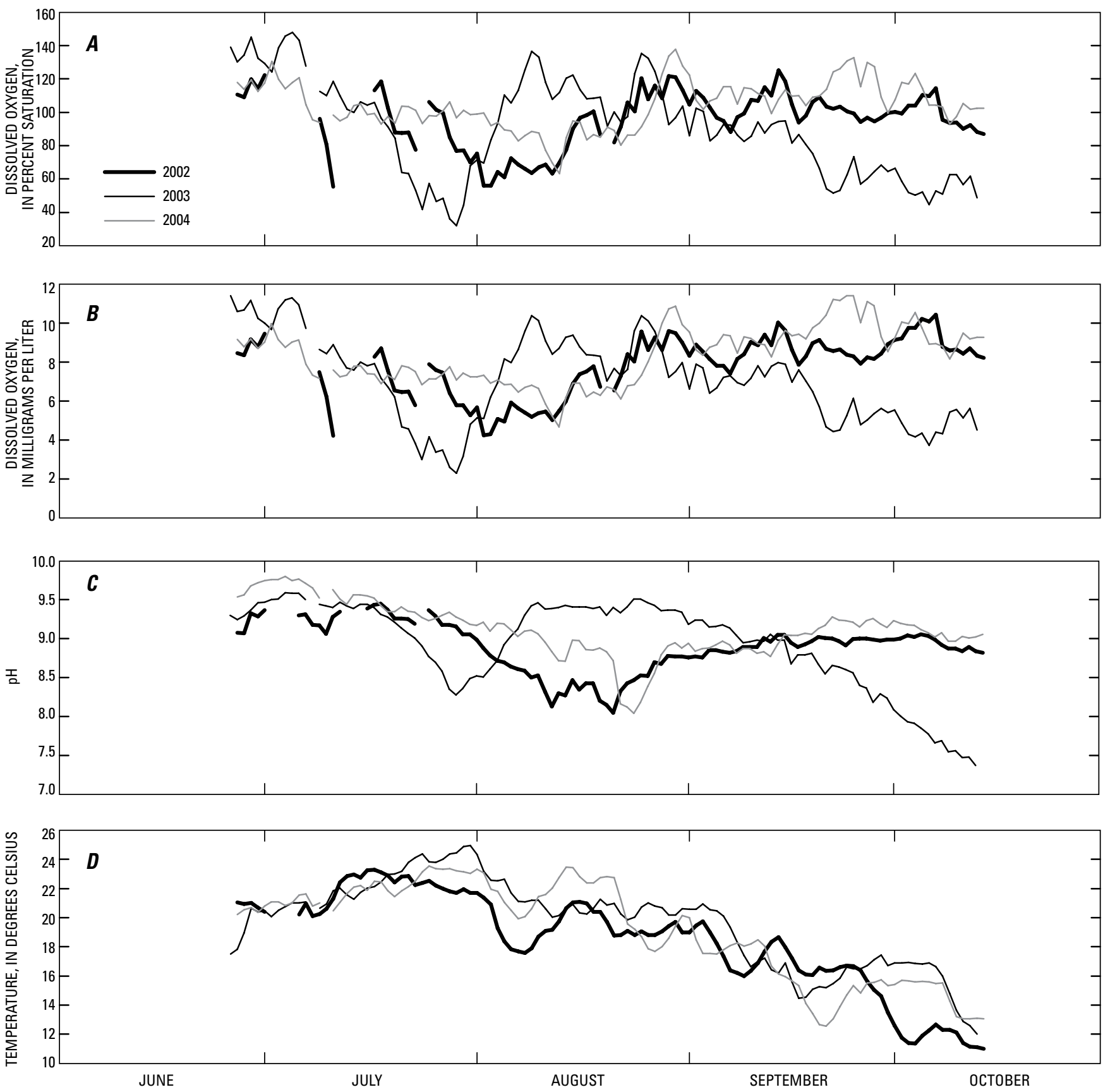

Figure 16. Daily medians of $(A)$ percent saturation of dissolved oxygen, $(B)$ dissolved oxygen concentration, $(C)$ $\mathrm{pH}$, and $(D)$ temperature for sites in Upper Klamath Lake, Oregon, 2002-04.

however, there were periods when the balance changed and photosynthetic production abated or stopped and/or oxygen demands increased, and the study-area daily median concentration of dissolved oxygen in the water column decreased to well below saturated conditions. Understanding what happens during these periods is of interest because dissolved oxygen can become low enough to produce chronic or acute stress on fisheries. These conditions were more common in 2003 than in 2002 or 2004, and notably the percent saturation and concentration of dissolved oxygen trended downward through the entire month of July 2003. The studyarea median concentration approached $2 \mathrm{mg} / \mathrm{L}$ and 20 percent saturation at the end of July 2003.

Study-area median $\mathrm{pH}$ conditions for 2002 and 2004 had a similar pattern. The $\mathrm{pH}$ increased early in the season and slowly decreased until mid-to-late August, following the same pattern of expansion and decline in the AFA bloom that is evident in the dissolved oxygen data. The $\mathrm{pH}$ then increased to greater than 9.0 and remained there for the rest of these field seasons. The study-area daily median $\mathrm{pH}$ for 2003 had 
the same pattern of higher $\mathrm{pH}$ in the early field season, but then showed large departures from those in the other 2 years. The $\mathrm{pH}$ decreased more abruptly in mid-to-late July than in the other 2 years of the study, mirroring the steep decrease in dissolved oxygen during this time. The study-area daily median $\mathrm{pH}$ then increased sharply in early August, hovered around 9.5 until late August, and then decreased for the rest of the field season to values in October that were much less than those in the other years of the study.

Temperatures increased from late June through late July, and then began a steady, decreasing trend from early August until the end of the field season. This general pattern is seen in all years, with the result that the highest temperatures in each of the 3 years of the study occurred around the end of July. Notable, however, is the fact that the highest temperatures of the 3 study years were observed at the end of July 2003. These temperatures exceeded the peak temperatures in the other 2 years by 2 to $3^{\circ} \mathrm{C}$. This may be significant because the July 2003 time period coincided with the lowest study-area median dissolved oxygen. High temperatures accelerate oxygen demanding processes and may have contributed to the low dissolved oxygen during this time.

\section{Occurrence and Duration of Water-Quality Conditions Potentially Harmful to Fish}

In order to identify periods when water-quality conditions potentially harmful to fish were present in the study area, and the spatial extent of these conditions, the hours when dissolved oxygen was less than $4 \mathrm{mg} / \mathrm{L}$, temperature was greater than $28^{\circ} \mathrm{C}$, or $\mathrm{pH}$ was greater than 9.7 were enumerated at each site. These values were based on high stress thresholds established to calculate stress indices for Upper Klamath Lake suckers (Reiser and others, 2000). The numbers of hourly occurrences of these conditions per day were summed over all of the sites to provide a count of "site-hours" per day of these conditions. To compare these counts of site-hours across years, the counts per day were divided by the total possible site-hours in the day ( 24 hours multiplied by the number of sites), giving a percentage of site-hours in the day that had potentially harmful conditions. This statistic provided a concise measure of the severity of the water-quality conditions across the study area during each day. To get a measure of the spatial extent of these potentially harmful conditions, the percentage of sites at which a potentially harmful condition was recorded at least 1 hour in a day was calculated. The study-area statistic was only computed when a daily statistic could be computed for 8 of the 11 individual sites, and the daily statistics were calculated at a site only for days on which at least 20 hours of data were available (figs. 17 and 18). Temperature is not included in the plots because temperature did not exceed $28^{\circ} \mathrm{C}$ in 2002 or 2004 , and exceeded $28^{\circ} \mathrm{C}$ at only one site for a few hours on 3 days in 2003.
During several periods in 2002, at least one instance of potentially harmful dissolved oxygen conditions per day was recorded at 10 percent or more of the sites in the study area. Before mid-August, there were several days during which almost 20 percent of the sites recorded a dissolved oxygen concentration less than $4 \mathrm{mg} / \mathrm{L}$; on one day in early August, 40 percent of the sites recorded dissolved oxygen concentration less than $4 \mathrm{mg} / \mathrm{L}$ (fig. 17A). During the second week in July and again during the second week in August, the percentage of site-hours during which concentrations less than $4 \mathrm{mg} / \mathrm{L}$ were recorded exceeded 60 percent, indicating that for a few days at a time the occurrence of these conditions was widespread and persistent throughout the day (fig. 18A). Occurrences of potentially harmful $\mathrm{pH}$ conditions were less common, but during a few days in late July, 10 percent or more of the sites recorded at least one $\mathrm{pH}$ reading greater than 9.7 (fig. 17B $)$. There were, however, relatively few site-hours for which conditions potentially harmful to fish were recorded for any parameter in 2002, indicating that the duration of these conditions at any one site generally was only a few hours during the day (fig. 18B).

The year 2003 was unique among the 3 study years in both the extent and daily duration of low dissolved oxygen conditions. From July 22 through July 31, 2003, a large fraction of the study area (as much as 60 percent of sites) had at least one dissolved oxygen measurement less than $4.0 \mathrm{mg} / \mathrm{L}$ in a day. During the same period, consistently high percentages (more than 60 percent) of the daily site-hours were characterized by concentrations less than $4.0 \mathrm{mg} / \mathrm{L}$. The combination of a large fraction of the study area having at least one dissolved oxygen reading per day less than $4.0 \mathrm{mg} / \mathrm{L}$ and a high percentage of daily site-hours having these conditions indicates that the spatial extent of this low dissolved oxygen event was large and that potentially harmful dissolved oxygen conditions persisted through most of the day during the event. The large percentage of sites (40-50 percent) and the consistently high percentage of site-hours (50 percent or greater for nearly 2 weeks) recording dissolved oxygen concentrations less than $4 \mathrm{mg} / \mathrm{L}$ in late September and early October also was unique (figs. 17A and 18A). Figures $17 \mathrm{~B}$ and $\underline{18 B}$ show that potentially harmful $\mathrm{pH}$ conditions in July and again in August and early September were, like the low dissolved oxygen conditions in late July, widespread throughout the study area and persistent throughout the day during these periods.

The 2003 statistics show that low dissolved oxygen conditions were more widespread throughout the study area and more persistent throughout the day for about 10 consecutive days between mid-July and early August than during any period in any of the other years. These water-quality conditions coincided with the beginning of a significant fish die-off event in 2003. In the period from July 22 to September 30, 2003, 108 endangered suckers were found dead in Upper Klamath Lake (B.J. Adams, U.S. Geological Survey, written commun., 2006). Widespread and 


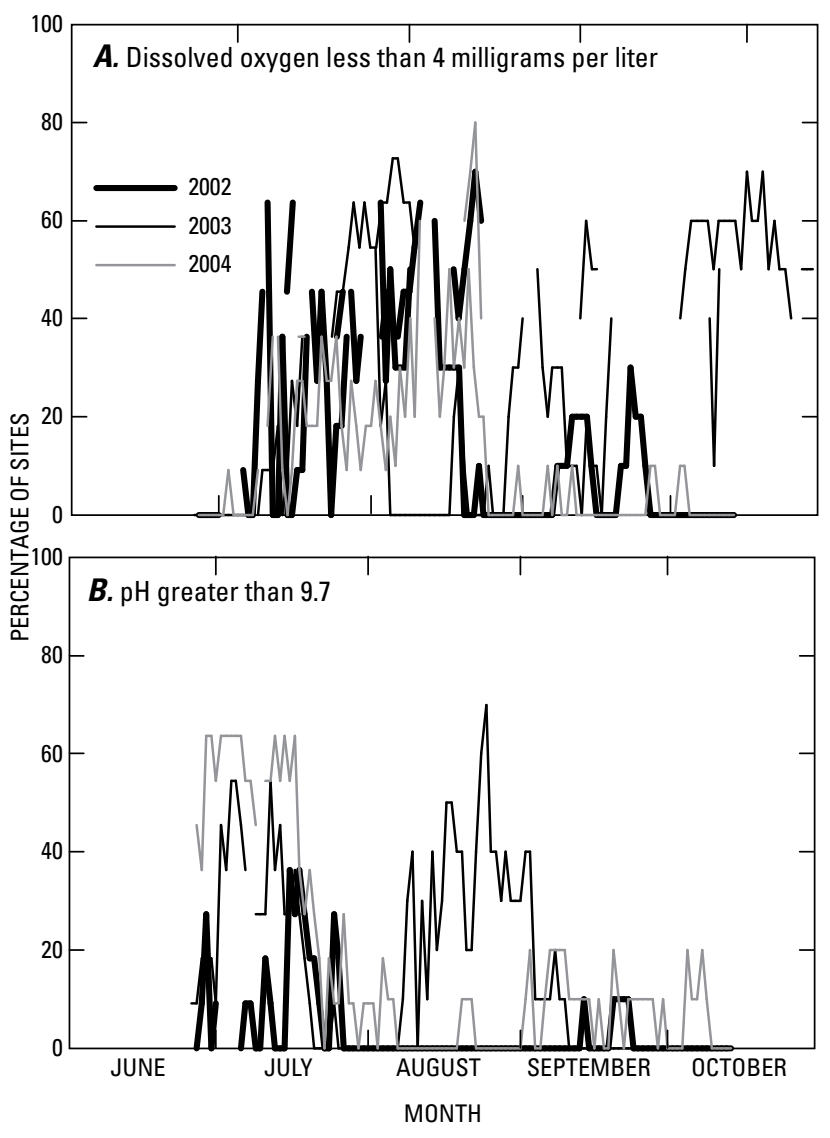

Figure 17. Percentage of sites recording at least one reading in the day of conditions potentially harmful to fish in Upper Klamath Lake, Oregon, 2002-04.

persistent $\mathrm{pH}$ conditions greater than 9.7 through much of the rest of the field season provided further potential to stress fish during 2003 and likely contributed to fish mortality in the latter part of the summer of that year.

Potentially harmful dissolved oxygen conditions were recorded at more than 20 percent of sites in 2004 during a few days in mid-August (fig. 17A), and the percentage of sitehours indicates that the conditions were widespread during those days (fig. 18A). A pH greater than 9.7 was recorded during more than 20 percent of the site-hours nearly every day over a 2-week period starting in late June of 2004, and the percentage peaked at more than 40 percent (fig. 17B). The potentially harmful $\mathrm{pH}$ conditions were widespread in the study area during this period, as indicated by the high percentage (more than 60 percent) of site-hours affected (fig. 18B).

\section{Location and Spatial Extent of Water-Quality Conditions Potentially Harmful to Fish}

The previous discussions have provided an overview of the occurrence and daily duration of poor water-quality conditions across the study area. It is also of interest to

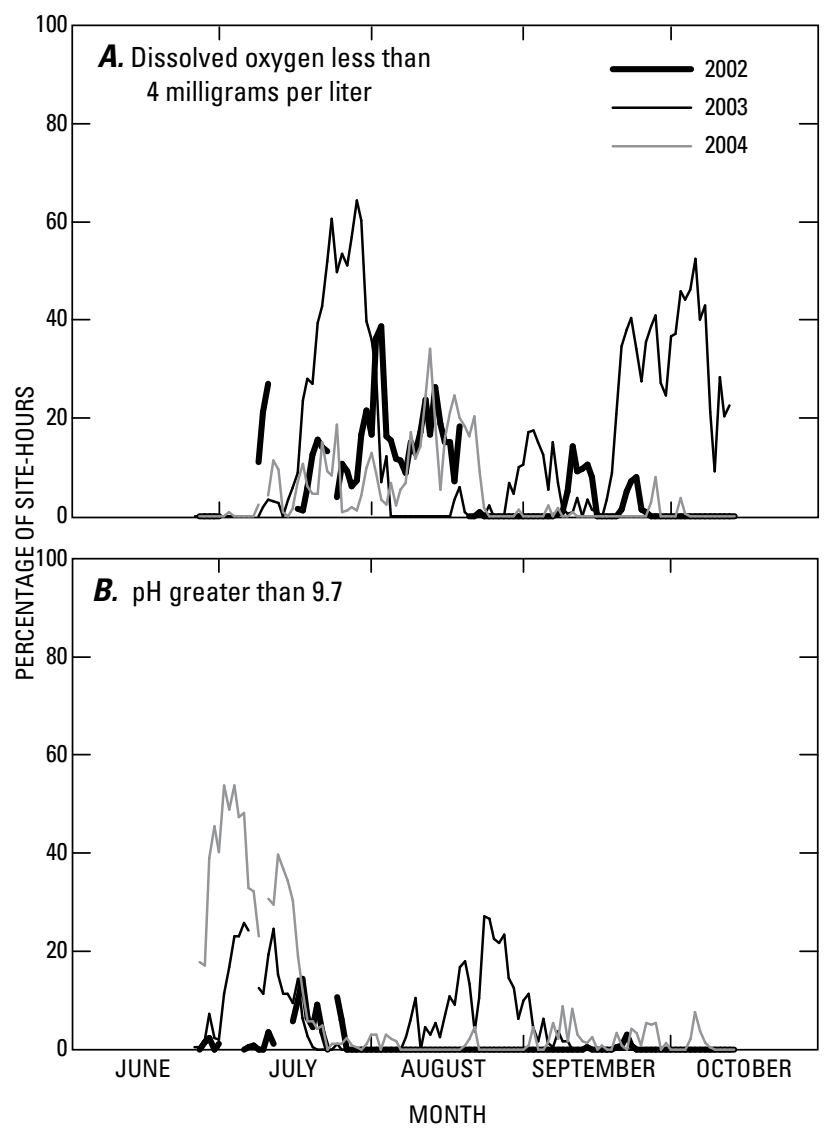

Figure 18. Percentage of total site-hours in the day having conditions potentially harmful to fish in Upper Klamath Lake, Oregon, 2002-04.

determine more specifically where these conditions occur, whether they tend to occur at the same sites in every year, whether the spatial extent is defined by a single, contiguous area or whether occurrences are scattered around the study area, and to get a quantitative estimate of the spatial extent.

To answer these questions, two-dimensional spline interpolations of the weekly median values at each site in each study year were generated using ArcGIS Spatial Analyst. The weekly time step was used because it allowed enough averaging to smooth the data while still capturing the important temporal changes during the season. The interpolations have limitations, however. First, the spacing of the sites in the network provides a lower limit on the length scale of spatial variability that can be resolved. At various times in each year, an effort was made to complete higher resolution transects between established sites in order to determine whether the dominant spatial scales were being resolved by the network. The results were inconclusive, as sometimes the transects showed little small-scale variability between network sites, although at other times there was more small-scale variability. A complicating factor seems to be that it is impossible to get a truly synoptic set of measurements, and the temporal variability in lake conditions is sometimes so great that what appears to be spatial variability is simply 
temporal variability over the traveltime along the transect. Nonetheless, the fact that the interpolations generally show smooth trends over the dimensions of the study area suggests that the dominant patterns are being resolved by the network. Second, the spline interpolation is a mathematical algorithm that fits a smooth surface through known values at known locations, but it does not incorporate equations describing the physics of the situation. For example, geographic features like Eagle Ridge that are real physical barriers are not seen as such by the interpolation. Another example is that physical features of the lake bathymetry that influence the water circulation and the distribution of water quality, like the trench, do not affect the interpolation. In this sense, the GIS interpolations are different from, for example, the visualization of the output of a numerical transport model. Even with these limitations, however, the GIS interpolations are a useful means of visualizing the spatial patterns in water quality and estimating the spatial extent of extreme conditions.

On the basis of GIS coverages of the interpolations, the spatial extent of dissolved oxygen concentrations less than $4 \mathrm{mg} / \mathrm{L}$ was estimated for each Julian week in each study year. From these results, it was determined that the maximum spatial extent of these conditions occurred between week 31 and 34 in all 3 years. (The dates corresponding to Julian weeks in each year are provided in table 2 for reference.) The results from these 4 weeks show how uniquely severe the conditions were in 2003, when the spatial extent of the weekly median of dissolved oxygen less than $4 \mathrm{mg} / \mathrm{L}$ reached a maximum of $39 \mathrm{~km}^{2}$ in Julian week 31 (table 3 ). In comparison, the maximum spatial extent of these conditions in 2004 was $2 \mathrm{~km}^{2}$ and in 2002 was $11 \mathrm{~km}^{2}$.

Even though there was a big difference in the severity of the lowest dissolved oxygen conditions between the 3 years of the study, the interpolations show consistency in the patterns of weekly median dissolved oxygen (fig. 19). Recall that the water-quality monitors are located at $1 \mathrm{~m}$ from the bottom, so the interpolations represent the concentrations on a surface that follows the bathymetry of the lake, $1 \mathrm{~m}$ from the bottom, rather than concentrations at or near the surface of the lake. The patterns that are evident, therefore, are a result of vertical as well as geographic differences in the location of the monitors. The highest concentrations generally occur toward the northern boundary of the study area, although the lowest concentrations tend to occur toward the southern end of the study area, along the segments of the trench that cross the entrances of Ball and Shoalwater Bays, and sometimes extend into the bays themselves. The patterns demonstrate that the lowest concentrations occur most often at the deeper sites (table 4).

Spatially, the range in values is quite large, from highly supersaturated (indicating photosynthetic production of dissolved oxygen in excess of consumption) to very undersaturated (indicating that respiratory and other consumptive processes exceed production). The 2003 map for week 31 shows a particularly large range in dissolved oxygen from north to south (from the shallower areas to the deeper
Table 2. Start dates of Julian weeks, 2002-04.

\begin{tabular}{cccc}
\hline $\begin{array}{c}\text { Julian } \\
\text { week }\end{array}$ & $\mathbf{2 0 0 2}$ & $\mathbf{2 0 0 3}$ & $\mathbf{2 0 0 4}$ \\
\hline 26 & $06-23$ & $06-21$ & $06-19$ \\
27 & $06-30$ & $06-29$ & $06-27$ \\
28 & $07-07$ & $07-06$ & $07-04$ \\
29 & $07-14$ & $07-13$ & $07-11$ \\
30 & $07-21$ & $07-20$ & $07-18$ \\
31 & $07-28$ & $07-27$ & $07-25$ \\
32 & $08-04$ & $08-03$ & $08-01$ \\
33 & $08-11$ & $08-10$ & $08-08$ \\
34 & $08-18$ & $08-17$ & $08-15$ \\
\hline
\end{tabular}

Table 3. Spatial extent of extreme water-quality conditions in Upper Klamath Lake, Oregon, 2002-04.

[Abbreviations: mg/L, milligram per liter. Symbol: <, less than]

\begin{tabular}{cccc}
\hline \multirow{2}{*}{$\begin{array}{c}\text { Julian } \\
\text { week }\end{array}$} & \multicolumn{3}{c}{$\begin{array}{c}\text { Spatial extent of extreme conditions } \\
\text { (square kilometers) }\end{array}$} \\
\cline { 2 - 4 } & $\mathbf{2 0 0 2}$ & $\mathbf{2 0 0 3}$ & $\mathbf{2 0 0 4}$ \\
\hline \multicolumn{4}{c}{ Median dissolved oxygen $<2 \mathrm{mg} / \mathrm{L}$} \\
\hline 29 & 0 & 0 & 0 \\
30 & 0 & 0 & 0 \\
31 & 0 & 22 & 0 \\
32 & 0 & 0 & 0 \\
33 & 0 & 0 & $<1$ \\
34 & 0 & 0 & 1 \\
\hline \multicolumn{4}{c}{ Median dissolved oxygen $<4 \mathrm{mg} / \mathrm{L}$} \\
29 & 0 & 3 & 0 \\
30 & 0 & 0 & $<1$ \\
31 & 11 & 39 & 2 \\
\hline
\end{tabular}

areas) in the study area. This period coincides with the major bloom decline in that year and reflects a steep decrease in dissolved oxygen in the deeper part of the study area that is associated with that decline. In all 3 years, the blooms tended to peak at higher values at the deeper sites, as evidenced by the general increase in median seasonal chlorophyll $a$ concentrations from the northern to the southern sites (fig. 15), and the effects of the bloom declines on dissolved oxygen were more severe at the deeper sites as well (fig. 19). In contrast, both the peaks of the bloom and the decreases in dissolved oxygen associated with a crash were moderated at the shallower sites toward the north and east in the study area.

The spatial extent of $\mathrm{pH}$ greater than 9.7 was at a maximum in late June in each study year, but among the 3 study years the extent was by far the greatest in 2004, encompassing as much as $47 \mathrm{~km}^{2}$ (table 3). Overall, bloom intensity was moderate in 2004 compared with that in the other 2 years (fig. 9), but the June peaks in chlorophyll $a$ were higher and apparent at more of the sites in 2004 than in 2002 or 2003. As a result, the spatial extent of extreme $\mathrm{pH}$ in June, 2004, was large, and the extreme values occurred with nearly the same frequency and daily duration at deep and shallow 
Table 4. Average number of hours per day in Julian weeks 31 to 34 that dissolved oxygen concentrations less than 4 milligrams per liter were measured at shallow and deep sites in Upper Klamath Lake, Oregon, 2002-04.

[Abbreviations: NA, insufficient data to make an estimate]

\begin{tabular}{|c|c|c|c|c|c|c|c|c|c|}
\hline Site & $\begin{array}{l}\text { Julian } \\
\text { week }\end{array}$ & \multicolumn{3}{|c|}{ Average number of hours per day } & Site & $\begin{array}{l}\text { Julian } \\
\text { week }\end{array}$ & \multicolumn{3}{|c|}{ Average number of hours per day } \\
\hline \multicolumn{5}{|c|}{ Shallow sites } & \multicolumn{5}{|c|}{ Deep sites } \\
\hline \multirow[t]{3}{*}{ UKL01 } & 31 & NA & 0 & 0 & UKL06 & 31 & 1.9 & 19.4 & 0 \\
\hline & 32 & ${ }^{1} 0$ & ${ }^{1} 0$ & ${ }^{1} 0$ & & 32 & ${ }^{1} 0$ & 0 & .4 \\
\hline & 33 & 1.9 & 0 & NA & & 33 & ${ }^{1} .3$ & 0 & .6 \\
\hline \multirow{3}{*}{ UKL02 } & 32 & 0 & 0 & 0 & & 32 & 10.7 & 0 & 0 \\
\hline & 33 & 0 & 0 & 2.6 & & 33 & 3.7 & 0 & .4 \\
\hline & 34 & NA & 0 & 0 & & 34 & ${ }^{1} .3$ & 0 & ${ }^{1} .1$ \\
\hline \multirow[t]{2}{*}{ UKL03 } & 31 & 0 & 0 & 0 & UKL08 & 31 & 14.1 & 19 & 7.3 \\
\hline & 32 & 0 & 0 & 0 & & 32 & 9.6 & 5.4 & 8.9 \\
\hline \multirow{2}{*}{ UKL04 } & 33 & 15.3 & 0 & 0 & & 33 & 10.7 & 0 & 0 \\
\hline & 34 & 2.7 & 0 & 1 & & 34 & 2 & 1.3 & 3 \\
\hline \multirow[t]{4}{*}{ UKL05 } & 31 & 0 & 3.4 & 0 & UKL11 & 31 & ${ }^{1} 8.9$ & 20.1 & 3.6 \\
\hline & 32 & NA & 0 & 0 & & 32 & ${ }^{1} 0$ & .4 & 5 \\
\hline & 33 & .3 & 0 & 1.6 & & 33 & ${ }^{1} .9$ & 0 & 17.6 \\
\hline & 34 & NA & 0.3 & 0 & & 34 & 0 & 0 & 13.9 \\
\hline \multirow[t]{4}{*}{ UKL09 } & 31 & 5.7 & 13.1 & NA & & & & & \\
\hline & 32 & 2 & 0 & ${ }^{1} 0$ & & & & & \\
\hline & 33 & 3 & 0 & 4.7 & & & & & \\
\hline & 34 & 0 & .7 & .4 & & & & & \\
\hline
\end{tabular}

${ }^{1}$ Value based on less than six fully sampled (20 out of 24 hours) days.

sites (table 5). At times, the spatial pattern in $\mathrm{pH}$ trended from higher values toward the north to lower values toward the south (fig. 20). This trend was particularly evident in 2004, and reflects the greater photosynthetic activity in the shallower areas to the north, where the entire water column is in the photic zone.

Temperatures greater than $28^{\circ} \mathrm{C}$ did not have a measurable spatial extent in any week of any year (fig. 21). Although there were a few periods in 2003 when temperatures exceeded $28^{\circ} \mathrm{C}$, those periods were extraordinary and of short duration, lasting less than half a day. The fact that temperatures greater than $28^{\circ} \mathrm{C}$ are rarely observed suggests that extreme temperature is not a significant contributor to chronic stress on fish health in at least the northern part of Upper Klamath Lake.

\section{Diel Variability}

Histograms showing the timing of daily minimum dissolved oxygen, daily maximum $\mathrm{pH}$, and daily maximum temperature at a representative deep site (defined as having a full pool depth greater than $2.5 \mathrm{~m}$ ) and shallow site (defined
Table 5. Average number of hours per day in Julian week 27 that $\mathrm{pH}$ greater than 9.7 was measured at shallow and deep sites in Upper Klamath Lake, Oregon, 2002-04.

[Abbreviations: NA, insufficient data to make an estimate]

\begin{tabular}{cccc}
\hline \multirow{2}{*}{ Site } & \multicolumn{3}{c}{ Average number of hours per day } \\
\cline { 2 - 4 } & $\mathbf{2 0 0 2}$ & $\mathbf{2 0 0 3}$ & $\mathbf{2 0 0 4}$ \\
\hline & Representative shallow sites \\
\hline UKL01 & 0 & 10.7 & 12.6 \\
UKL02 & 1.7 & 8.6 & 18.8 \\
UKL03 & 3.3 & 2.9 & 18.1 \\
UKL04 & .1 & 6.3 & 23.3 \\
UKL05 & NA & 11 & 7.9 \\
UKL09 & 0 & .4 & 11.3 \\
\hline & Representative deep sites & 6.3 \\
UKL06 & NA & 6.4 & 14.4 \\
UKL07 & NA & 10 & 0 \\
UKL08 & 1.4 & 0 & 9.4 \\
UKL10 & 0 & 3.4 & 0 \\
UKL11 & 0 & 0 &
\end{tabular}

${ }^{1}$ Value based on less than six fully sampled (20 out of 24 hours) days. 


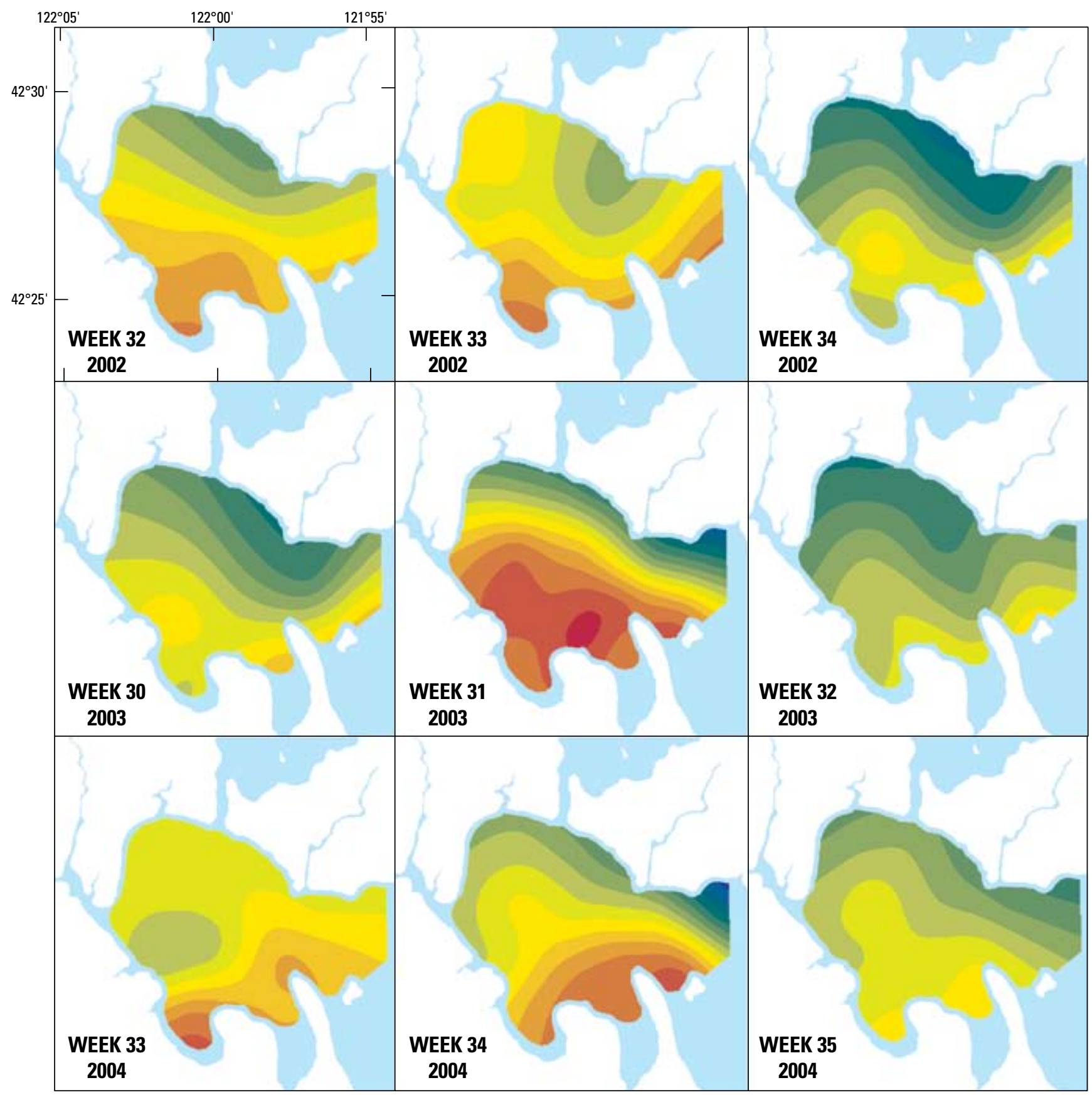

EXPLANATION

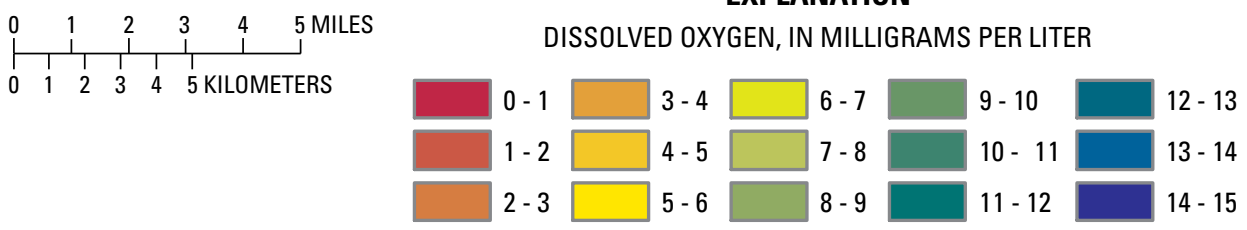

Figure 19. Geographic Information System coverage of an interpolation of weekly median dissolved oxygen concentrations, Julian weeks 31-34, Upper Klamath Lake, Oregon, 2002-04. 

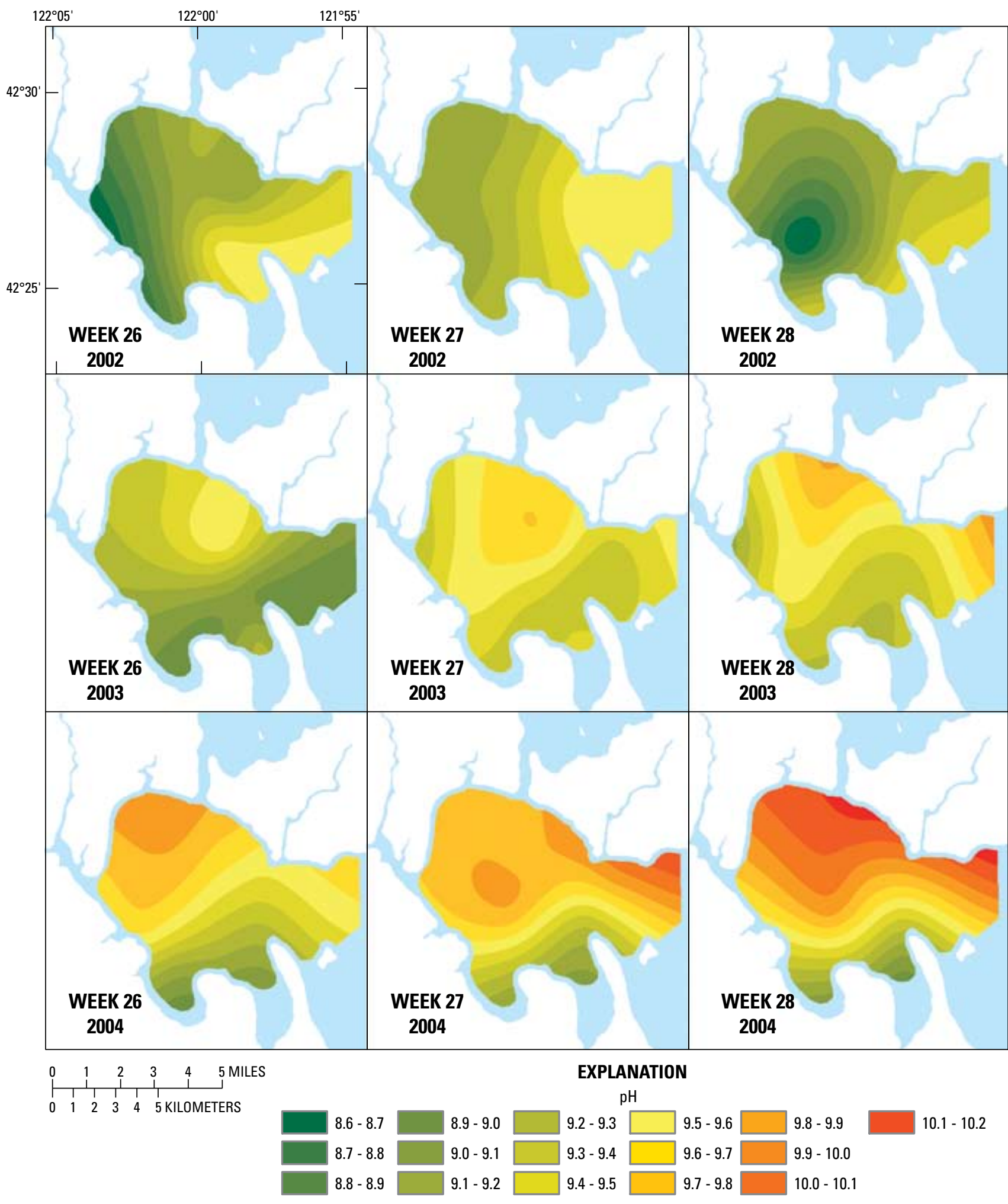

Figure 20. Geographic Information System coverage of an interpolation of weekly median pH, Julian week 27, Upper Klamath Lake, Oregon, 2002-04. 

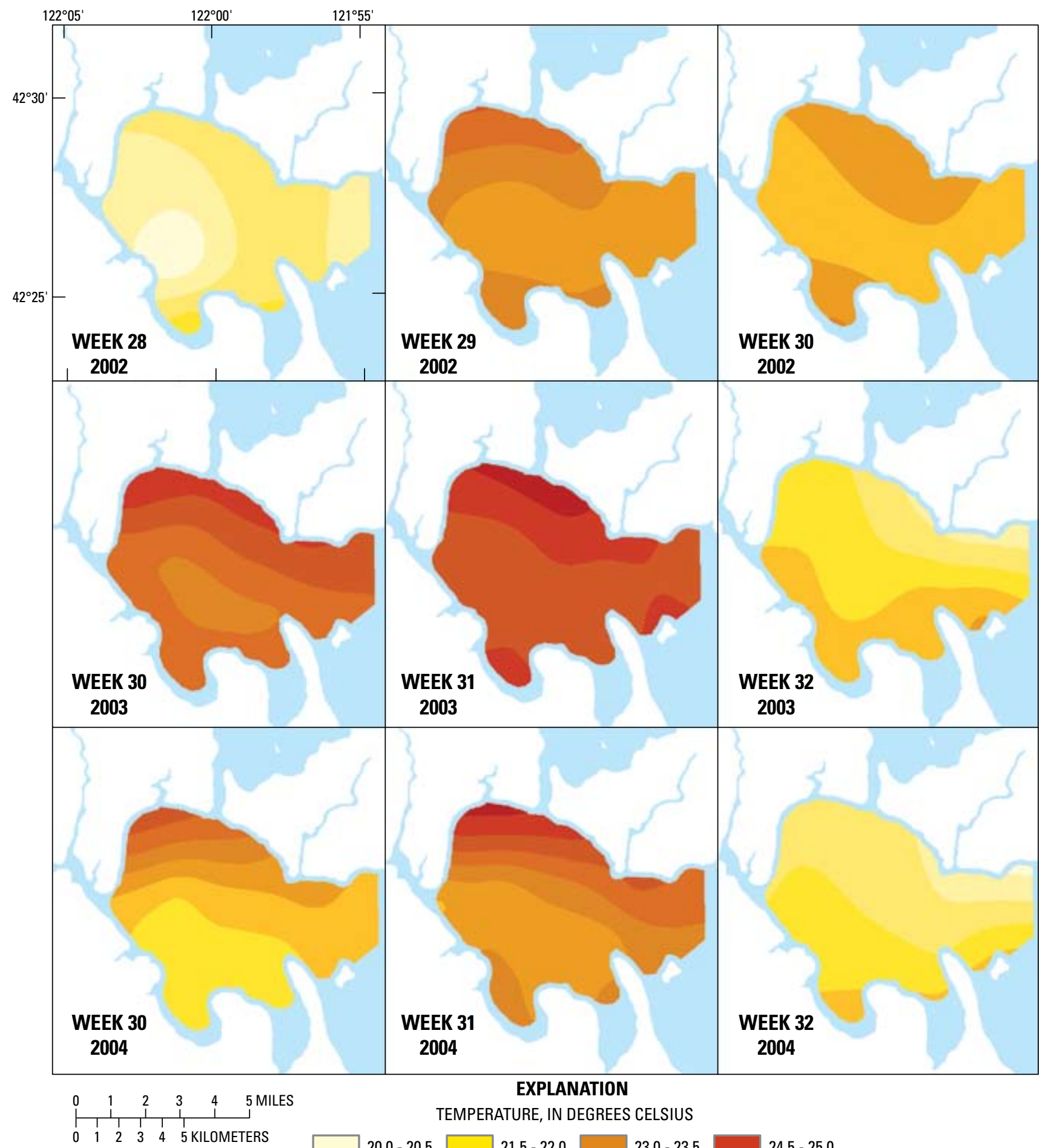

EXPLANATION

TEMPERATURE, IN DEGREES CELSIUS

\begin{tabular}{|c|c|c|c|}
\hline $20.0-20.5$ & $21.5-22.0$ & $23.0-23.5$ & $24.5-25.0$ \\
\hline $20.5-21.0$ & $22.0-22.5$ & $23.5-24.0$ & $25.0-25.5$ \\
\hline $21.0-21.5$ & $22.5-23.0$ & $24.0-24.5$ & $25.5-26.0$ \\
\hline
\end{tabular}

Figure 21. Geographic Information System coverage of an interpolation of weekly median temperature, Julian week 31 , Upper Klamath Lake, Oregon, 2002-04. 
as having a full pool depth less than $2.5 \mathrm{~m}$ ) are shown in figure 22. These histograms display the normalized frequency of occurrence of the daily extreme water-quality reading as a function of the hour of day the most extreme water-quality reading occurred. Data from all 3 years were combined to create these histograms after determining that data from each of the 3 years showed the same patterns. Histograms for shallow sites were similar to each other, as were the histograms for the deeper sites. A representative shallow site (UKL02) and a representative deep site (UKL07) were chosen to illustrate the results. It is helpful to recall that the monitors used in this study were located at $1 \mathrm{~m}$ off the bottom, so at shallow sites they are located within the photic zone, whereas at deep sites they are located below the photic zone.

Daily minimum dissolved oxygen concentration at the shallow sites tended to occur around 7 a.m. (fig. 22A). Daily maximum $\mathrm{pH}$ and temperature occurred most frequently in the early evening between the hours of 4 p.m. and 8 p.m. (fig. $22 B$ and $22 C$ ). This pattern reflects the strong influence of the diel cycle of photosynthesis and respiration on the water column, which is almost entirely within the photic zone at these sites.

At deep sites, however, there was no distinct period of the day when daily minimum dissolved oxygen conditions tended to occur (fig. 22D). The maximum pH at the deep sites tended to occur in late afternoon, but over a much broader window of time than at the shallow sites, lasting from the hours of about 4 p.m. to 2 a.m. the next morning (fig. $22 E$ ). Temperature at the deep sites behaved much like temperature at the shallow sites, usually peaking in a narrow window between the hours of about 5 p.m. and 9 p.m. in the late afternoon (fig. $22 F$ ).

At the deep sites, only the surface (roughly the top $2 \mathrm{~m}$ ) of the water column is in the photic zone. In the lower part of the water column, below the photic zone, the rate of consumption of dissolved oxygen by metabolic respiration and other oxygen demanding processes within the water column is greater than the rate of production of oxygen by photosynthesis. Near the bottom, sediment oxygen demand also consumes dissolved oxygen from the water. Temperature differences between the upper and lower water column can produce some degree of thermal (density) stratification, which isolates the lower from the upper water column. If the water column develops even a small degree of stratification, it then becomes possible for dissolved oxygen to reach minimum daily conditions in the lower part of the water column (where site monitors were located) at any time during the day, even during daylight hours. This is because dissolved oxygen below the photic zone will continue to decrease until a mixing event erodes the thermal stratification and mixes the lower layer with the upper layer, which is at a relatively higher concentration. At a deep site, therefore, the minimum in dissolved oxygen does not always occur in the early morning hours just before dawn, but rather can occur throughout the day depending on when the wind picks up and mixes the water column.

At the shallow sites, a secondary maximum in $\mathrm{pH}$ and temperature occurs at midnight (figs. $22 B$ and $22 C$ ). On close inspection of individual time series, it was determined that this secondary maximum occurs on a significant subset of days when the parameter ( $\mathrm{pH}$ or temperature) is trending strongly downward. In that case, the change in the parameter over the day from midnight to midnight is greater than the upward and downward movement due to solar radiation during the day, with the result that the maximum occurs at the beginning of the day instead of some other time during the day. Similarly, when dissolved oxygen is trending strongly downward, the minimum of the day occurs at 11 p.m. for the same reason (fig. 22A). When the parameters are trending strongly upward, the opposite (maximum in $\mathrm{pH}$ and temperature at 11 p.m.; minimum in dissolved oxygen at midnight.) does not occur as often because of the asymmetry in the diel cycle, which is heavily skewed toward the late afternoon, thus making it less likely that a value at the end of the day will end up being an extreme value. A strong secondary maximum in temperature at midnight also is seen at the deep site (fig. $22 F$ ). The trends and diel cycle in temperature in the lower layer of the deep water column develops in response to the same atmospheric forcing that operates at the shallow sites, so the timing of extreme values is similar, but the magnitude of the diel fluctuations generally is dampened in comparison to that at the shallow site. 

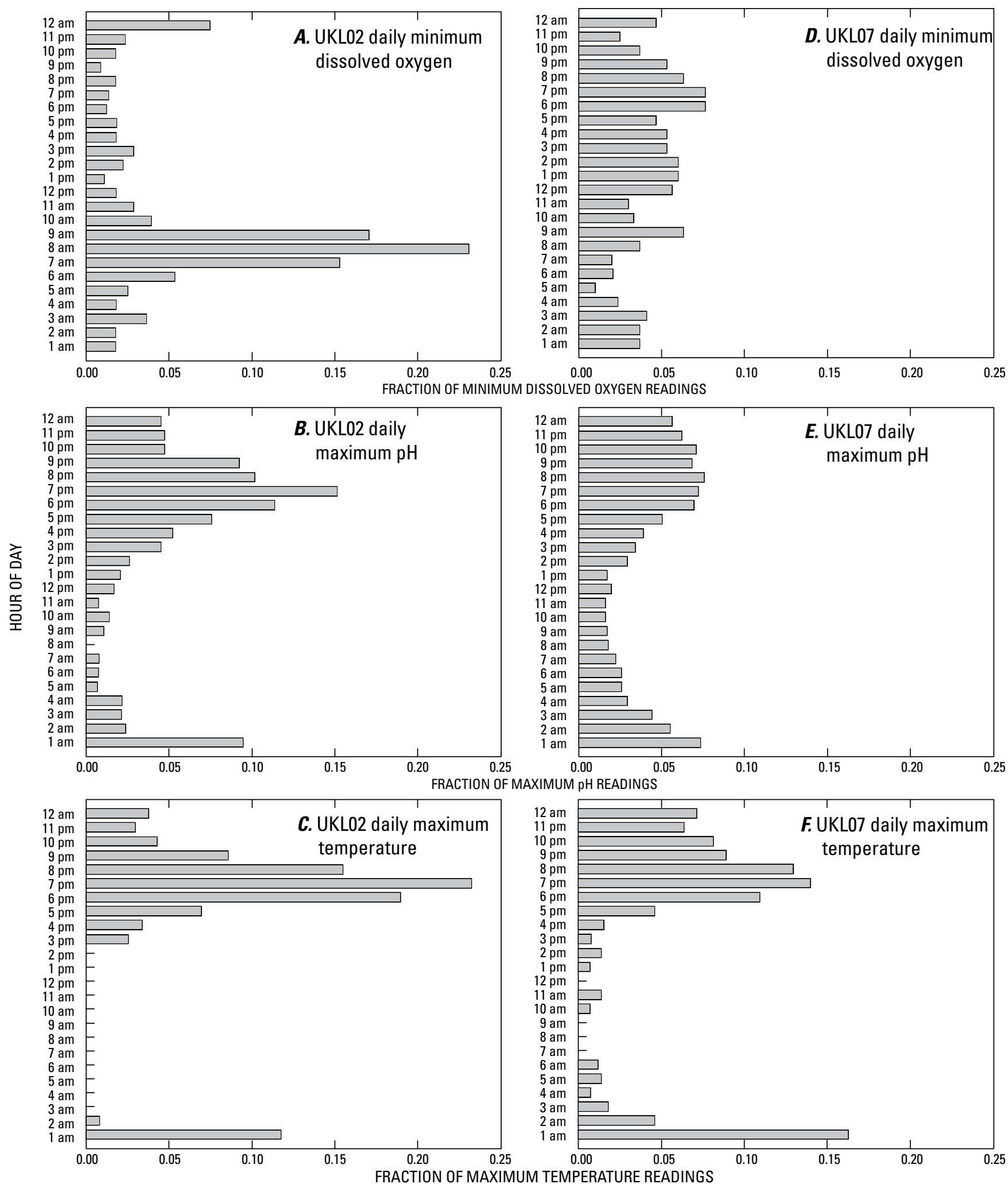

Figure 22. Daily extremes in water-quality conditions as a function of hour in the day, at representative shallow (UKL02) and deep (UKL07) sites in Upper Klamath Lake, Oregon, 2002-04. Data for 2002-04 have been combined. 


\section{Factors Contributing to Low Dissolved Oxygen Events}

To this point the presentation of the data has focused on three aspects of water quality that contribute to chronic stress on endangered suckers when they exceed or fall below certain limits - dissolved oxygen, $\mathrm{pH}$, and temperature. An analysis of all possible causes of mortality during fish die-offs in the mid1990s concluded, however, that mortality was ultimately the result of hypoxia, even considering that substantial mortality occurred after hypoxic conditions had abated, because hypoxia had compromised the immune systems of the fish and left them vulnerable to infection (Perkins and others, 2000). Observations of the fish die-off in 2003 were consistent with this conclusion, in that they indicated that the role of hypoxia was to force fish into crowded conditions in the vicinity of Pelican Bay, where many eventually succumbed to disease (B.J. Adams, U.S. Geological Survey, oral commun., 2005). For that reason, the following discussion focuses on the probable causes for the occurrence of a low dissolved oxygen event (LDOE) in the study area, which encompasses the area of the lake that is the preferred habitat of adult suckers.

For the purposes of discussion it is useful to define an LDOE quantitatively. There are several ways to do this; four were chosen, and the time periods that emerge in each year as a result of those four definitions are compiled in table 6. A few dates consistently emerge in each year when all but the most stringent definition is used-August 1-2 in 2002,

Table 6. Dates of low dissolved oxygen events in the northern part of Upper Klamath Lake, Oregon, 2002-03.

[Dates were determined using four criteria: 1, percentage of site-hours with dissolved oxygen concentrations < (less than) $4 \mathrm{mg} / \mathrm{L}$ (milligrams per liter) was greater than or equal to 20 percent; 2 , percentage of site-hours with dissolved oxygen concentrations $<4 \mathrm{mg} / \mathrm{L}$ was greater than or equal to 25 percent; 3 , study area median dissolved oxygen concentration was $<80$ percent of saturation; and 4, percentage of site-hours with dissolved oxygen concentration $<4 \mathrm{mg} / \mathrm{L}$ was greater than or equal to 50 percent]

\begin{tabular}{crrr}
\hline \multirow{2}{*}{ Criterion } & \multicolumn{3}{c}{ Dates } \\
\cline { 2 - 4 } & \multicolumn{1}{c}{ 2002 } & 2003 & \multicolumn{1}{c}{$\mathbf{2 0 0 4}$} \\
\hline \multirow{2}{*}{1} & $07-10-07-11$ & $07-18-08-02$ & $08-12-08-13$ \\
& $07-31$ & $09-20-10-09$ & $08-17-08-19$ \\
& $08-02-08-3$ & $10-11-10-13$ & $08-22$ \\
& $08-12$ & & $08-13$ \\
2 & $08-02-08-03$ & $07-19-08-02$ & \\
& & $09-21-09-29$ & $08-11-08-13$ \\
3 & & $10-01-10-08$ & \\
& $07-10$ & $07-21-08-02$ & None \\
\hline
\end{tabular}

July 23 to August 2 in 2003, October 1-8 in 2003, and August 13 in 2004. When an LDOE is defined as 50 percent or more of site-hours having a dissolved oxygen concentration less than $4 \mathrm{mg} / \mathrm{L}$, then only the period July 23-30 in 2003 meets the definition. By combining the various datasets collected during this study, including weekly chlorophyll $a$ samples, meteorological data, water-quality profiles from the profiling buoys, and, in 2003 and 2004, the ADCP current data, it has been possible to evaluate three of the factors that contribute to an LDOE - thermally stable conditions, a bloom decline, and the wind-driven circulation.

\section{Water Column Stratification}

The profiling buoys collected observations of dissolved oxygen concentration over the water column between $1 \mathrm{~m}$ off the bottom and $1 \mathrm{~m}$ from the surface (figs. 23-25). Even though the degree of stratification in Upper Klamath Lake is moderate compared with that of deeper lakes, it has implications for water quality. Stratification isolates a near-bottom layer of water, allowing oxygen demanding processes to deplete this layer of oxygen and potentially creating unsuitable conditions for endangered suckers. These oxygen depleted conditions do not usually extend throughout the water column, however, because stratification also tends to create favorable conditions for AFA in the upper layer. The AFA cells can regulate their buoyancy and thereby maintain a position close to the surface; consequently, the upper water column tends to become supersaturated with respect to dissolved oxygen during periods of stratification.

Because stratification rarely persists from day to day, the relatively oxygen-rich upper water column and the relatively oxygen depleted lower water column are usually mixed together on a daily basis. That is why the maximum concentration of the day at the profiling buoys was usually greater than the value of concern of $4 \mathrm{mg} / \mathrm{L}$ (figs. 23-25) even when the minimum of the day was less than this value, and why the concentration in the mixed water column (indicated by the daily minimum difference between the upper and lower monitors) usually was greater than $4 \mathrm{mg} / \mathrm{L}$ even on days when the minimum of the day was less than this value. The daily maximum range in dissolved oxygen concentration between the upper and lower water column generally was such that the upper water column was characterized by concentrations tolerable to fish (greater than $4 \mathrm{mg} / \mathrm{L}$ ) even when the lower water column was characterized by concentrations severely stressful to fish or even lethal. These observations from the profiling buoys suggest that periods when habitat is limited by water quality to only part of the water column and to less than a full day are common. Observations of fish behavior during 2002-04 suggest that the endangered suckers are, for the most part, able to survive through these periods, although the effects of the chronic stress that accompanies these conditions cannot be determined from tracking studies. 


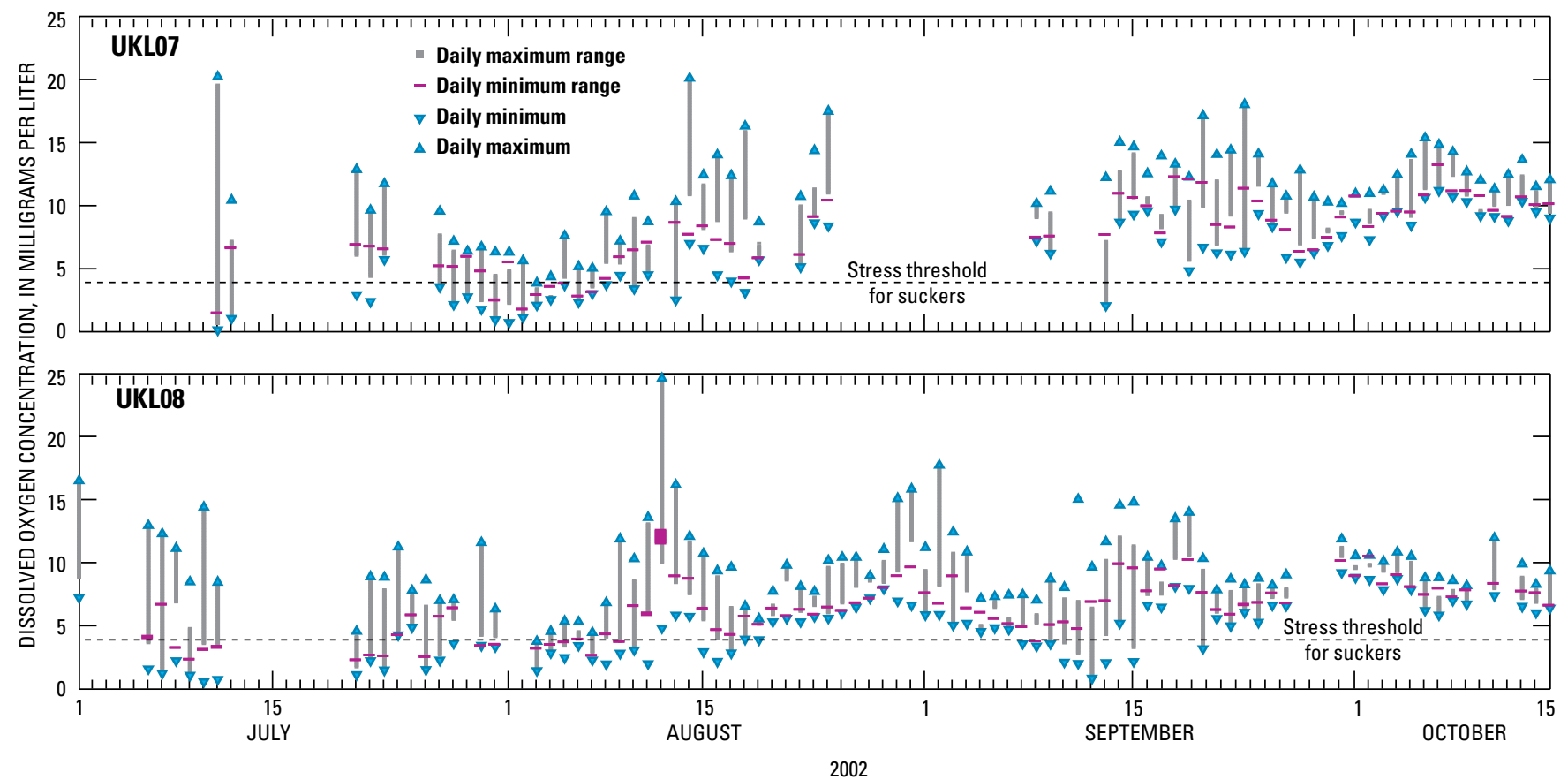

Figure 23. Daily minimum and maximum ranges in dissolved oxygen over the water column and minimum and maximum dissolved oxygen from hourly values collected at 1 meter off the bottom and 1 meter from the surface at sites UKL07 and UKL08 in Upper Klamath Lake, Oregon, 2002.

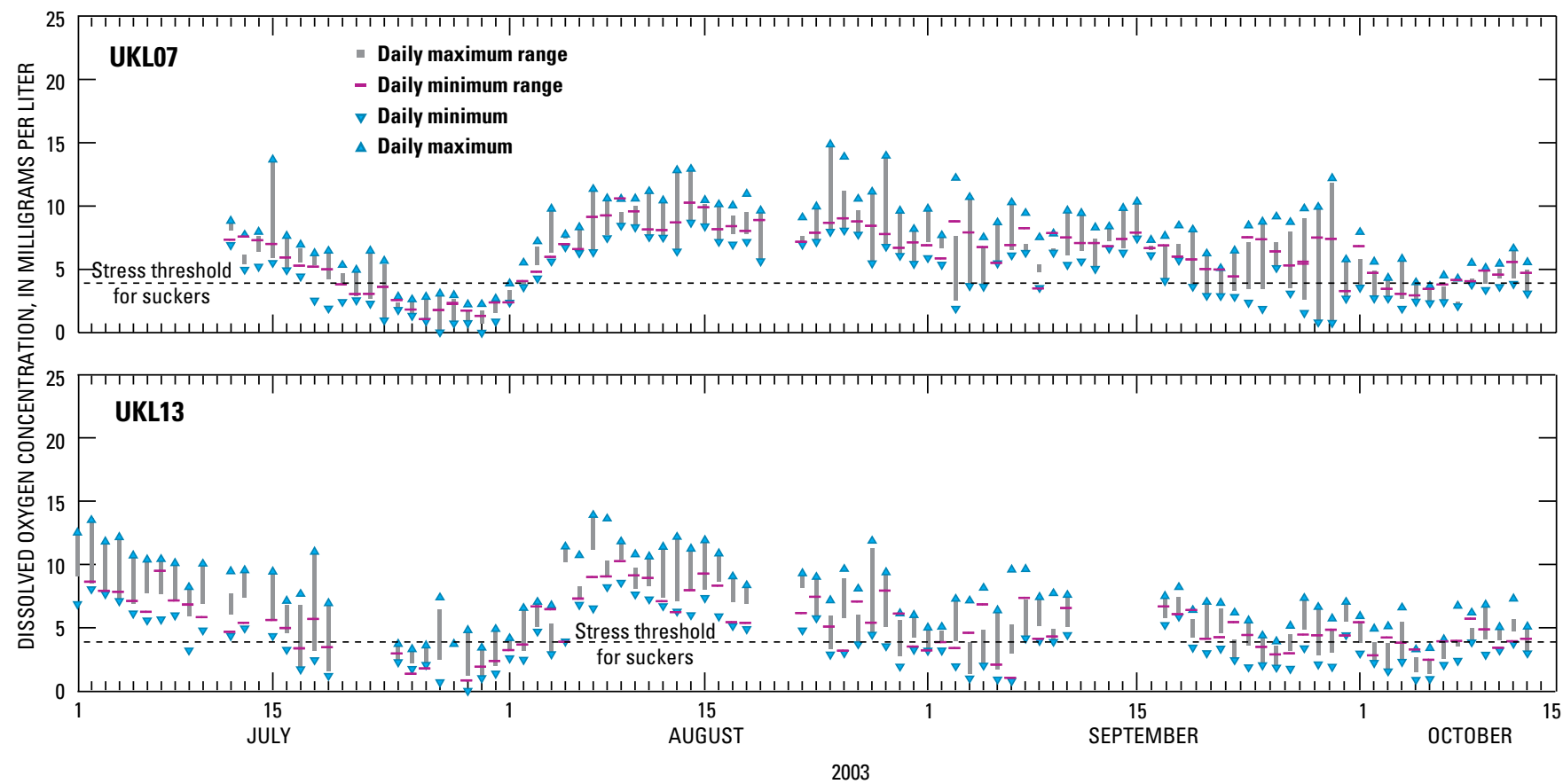

Figure 24. Daily minimum and maximum ranges in dissolved oxygen over the water column and minimum and maximum dissolved oxygen from hourly values collected at 1 meter off the bottom and 1 meter from the surface at sites UKL07 and UKL13 in Upper Klamath Lake, Oregon, 2003. 


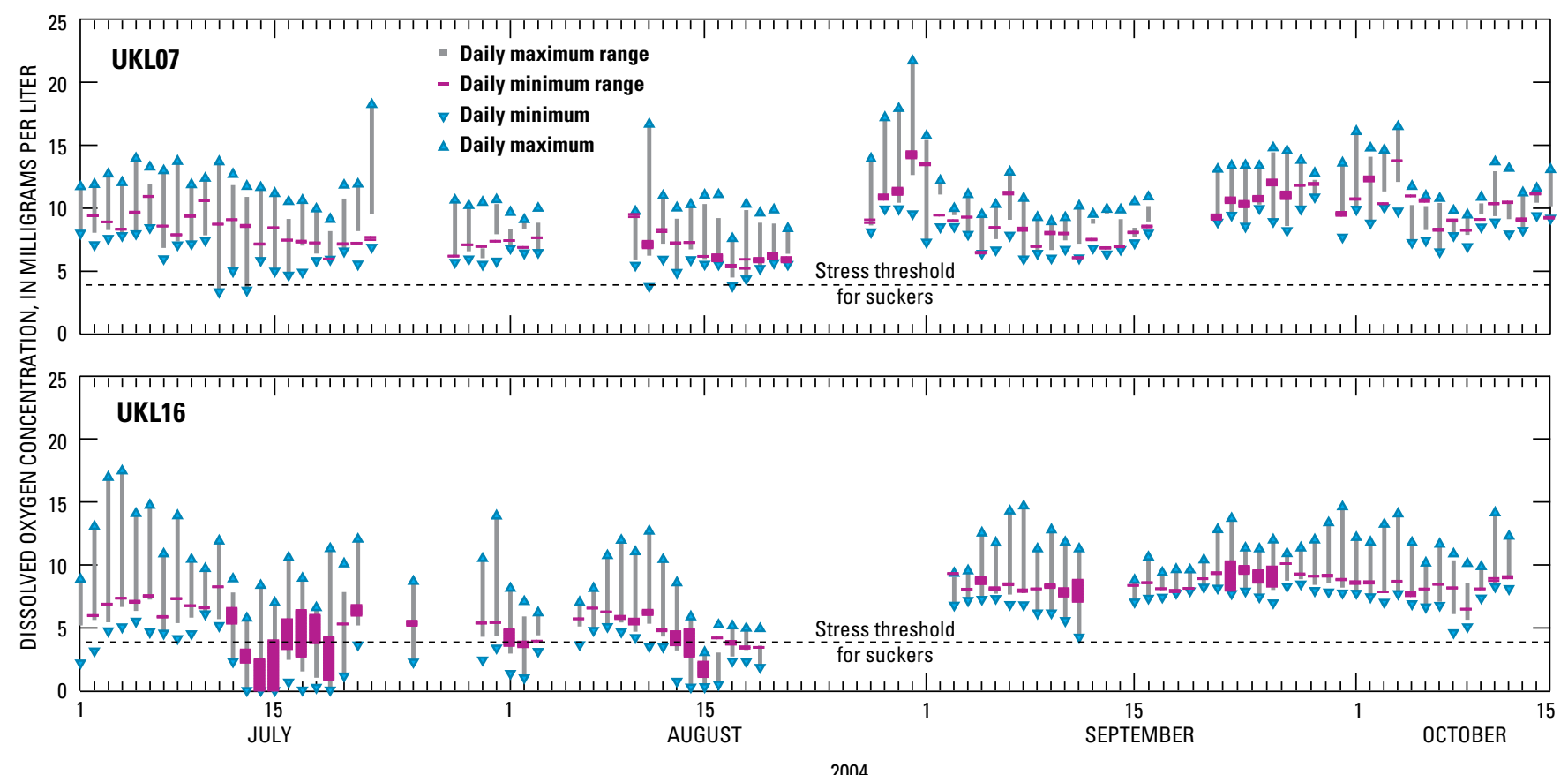

Figure 25. Daily minimum and maximum ranges in dissolved oxygen over the water column and minimum and maximum dissolved oxygen from hourly values collected at 1 meter off the bottom and 1 meter from the surface at sites UKL07 and UKL16 in Upper Klamath Lake, Oregon, 2004.

The periods of increased surface-to-bottom difference in dissolved oxygen were related to periods of enhanced stratification, as indicated by an increased surface-to-bottom difference in temperature (fig. 26). These two quantities were highly correlated on a daily basis in all 3 years (table 7). This did not, however, translate into a high correlation between enhanced stratification, as measured by either increased surface-to-bottom difference in temperature or increased surface-to-bottom difference in dissolved oxygen concentration, and the minimum daily dissolved oxygen (fig. 26). These quantities were only significantly and negatively correlated in 2002 (table 7). Thus, the occurrence of the lowest minimum dissolved oxygen concentrations is not necessarily associated with a high degree of water column stratification, although some LDOE dates appear to coincide with a stratified water column-July 10 , July 23, July 30, August 8-13 in 2002, September 25-29 in 2003, and August 11-12 and August 19 in 2004.

The relation between wind speed, water column stratification, and daily minimum dissolved oxygen was not straightforward. On a daily basis, wind speed was significantly and negatively correlated with water column stratification, as measured by the surface-to-bottom difference in temperature, in 2002 and 2004, but not in 2003. The correlation between wind speed and daily surface-to-bottom difference in dissolved oxygen concentration was significant in all 3 years (fig. 26 and table 7). Kann and Welch (2005) noted an inverse correlation between wind speed and the surface-to-bottom difference in dissolved oxygen when profile data collected from 1990 to 2000 were averaged over the entire July-August period; in this study the relation appears to hold on a daily basis as well. The correlation between daily wind speed and daily minimum dissolved oxygen, however, was insignificant in 2002, weakly positive in 2003, and weakly negative in 2004 (table 7). So, although wind speed clearly influences the degree of stratification in the water column, it has less influence over when the lowest dissolved oxygen concentrations occur. Some of the LDOE dates were associated with low wind speeds; many were not.

Significantly, the most severe LDOE of the 3 study years, which occurred in July 2003, was not associated with stratification of the water column. Concentrations during the last week in July were about $3 \mathrm{mg} / \mathrm{L}$ or less during the entire day and throughout the water column at site UKL07 (fig. 24). Data from the other monitoring sites showed that low concentrations were widespread during a period of several days (fig. 19), meaning that habitat in the entire southwestern part of the study area was unsuitable throughout the water column and throughout the day for several days. The distinction between the severity of the LDOE of July 2003 and times during 2002-04 when water quality was perhaps chronically stressful but not lethal appears to have been important to the endangered suckers in the lake. The suckers responded to the 2003 event by leaving the area (B.J. Adams, U.S. Geological Survey, oral commun., 2004), whereas they generally remained in place in other years during times when the lowest dissolved oxygen concentrations were less than 4 $\mathrm{mg} / \mathrm{L}$ near the bottom but moderated slightly both closer to the surface and at intervals during the day. 


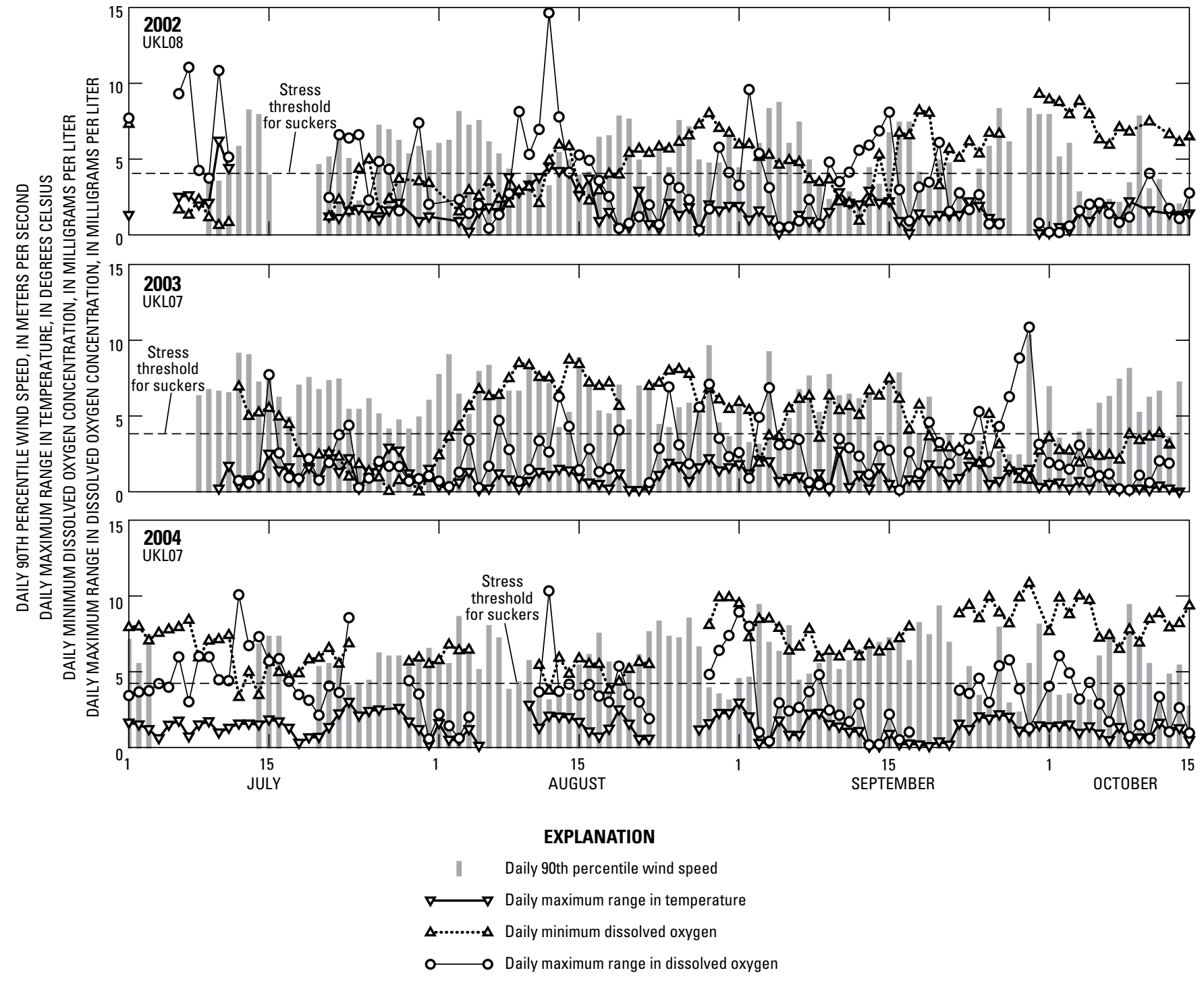

Figure 26. Daily maximum range in dissolved oxygen concentration over the water column, maximum range in temperature over the water column, minimum water column dissolved oxygen concentration, and $90^{\text {th }}$ percentile of hourly wind values in Upper Klamath Lake, Oregon, 2002-04. 
Table 7. Spearman's rho correlation coefficients between daily values derived from hourly data collected at site UKL08 in 2002 and site UKL07 in 2003-04, Upper Klamath Lake, Oregon.

[Wind speed: daily 90th percentile of hourly values. Max $\Delta \mathbf{T}$, daily maximum range in temperature based on hourly values collected at $1 \mathrm{~m}$ (meter) from the bottom and $1 \mathrm{~m}$ from the surface. Max $\Delta \mathbf{D O}$, daily maximum range in dissolved oxygen based on hourly values collected at $1 \mathrm{~m}$ from the bottom and $1 \mathrm{~m}$ from the surface. Min DO, daily minimum dissolved oxygen of hourly values collected at $1 \mathrm{~m}$ from the bottom and $1 \mathrm{~m}$ from the surface. Boldface type indicates significant correlation $(p<0.001)$. Boldface italicized type indicates significant correlation $(p<0.05)]$

\begin{tabular}{lccccc}
\hline & Year & $\begin{array}{c}\text { Wind } \\
\text { speed }\end{array}$ & Max. $\Delta \mathbf{T}$ & Max. $\Delta \mathbf{D O}$ & Min. DO \\
\hline Wind speed & 2002 & 1.00 & $\mathbf{- 0 . 4 5}$ & $\mathbf{- 0 . 2 8}$ & -0.03 \\
& 2003 & 1.00 & -0.11 & $\mathbf{- 0 . 2 8}$ & $\mathbf{0 . 3 2}$ \\
& 2004 & 1.00 & $\mathbf{- 0 . 3 6}$ & $\mathbf{- 0 . 4 3}$ & $\mathbf{- 0 . 2 8}$ \\
Max. $\Delta \mathrm{T}$ & 2002 & & 1.00 & $\mathbf{0 . 6 3}$ & $\mathbf{- 0 . 3 7}$ \\
& 2003 & & 1.00 & $\mathbf{0 . 6 4}$ & -0.17 \\
& 2004 & & 1.00 & $\mathbf{0 . 7 8}$ & 0.03 \\
Max. $\Delta \mathrm{DO}$ & 2002 & & & 1.00 & $\mathbf{- 0 . 4 4}$ \\
& 2003 & & & 1.00 & 0.05 \\
& 2004 & & & 1.00 & -0.06 \\
Min. DO & 2002 & & & & 1.00 \\
& 2003 & & & & 1.00 \\
& 2004 & & & & 1.00 \\
\hline
\end{tabular}

Sites UKL07 and UKL08 were in similar water depths (table 1), and the 2002 data from these sites show that the periods when very low dissolved oxygen was observed and the periods of maximum vertical variability in dissolved oxygen over the water column were similar as well (fig. 23). Data collected by profiling buoys in 2003 from sites UKL07 and UKL13, sites that were in similar water depths, show a corresponding similarity in periods when low dissolved oxygen was observed in the lower water column (fig. 24). In 2004, however, one of the profiling buoys was moved to site UKL16, a site in the middle of the trench on the western side of the lake (fig. 1). This site was much deeper than any of the sites where profiling buoys were located previously, and the data show that very low near-bottom dissolved oxygen developed more readily at this site than at any of the shallower sites. There was very little evidence of low nearbottom dissolved oxygen at site UKL07 in 2004, but there were several periods when low concentrations developed in the trench at UKL16 (July 12-20, July 30-August 3, and August 13-19, fig. 25). The causes and implications of the development of these conditions in the trench area are discussed below in the context of the wind-driven circulation.

\section{Bloom Decline}

In a hypereutrophic water body like Upper Klamath Lake, a shutdown or sharp decline in the rate of photosynthesis can cause a rapid decrease in dissolved oxygen concentration. This decrease occurs because the rate of oxygen demanding processes, which can be high in lakes with large amounts of labile organic matter in the water column and the surficial sediments, continue unabated while the rate of oxygen production ceases or slows markedly. Senescing cells also add to the oxygen demand in the water column. During the 3 years of this study, bloom declines seem to have contributed to several LDOEs.

In 2002, the bloom decline, as estimated from weekly chlorophyll $a$, occurred between about July 19 and August 1, so it preceded and then overlapped the LDOE between July 31 and August 3 (table 6). By one definition, this LDOE lasted until August 13, but chlorophyll $a$ concentrations largely recovered, although not to prebloom concentrations, during the first 2 weeks in August, so it seems unlikely that the bloom decline could be the primary cause of the undersaturated dissolved oxygen conditions that lasted until August 13. The timing of the LDOE was coincident with elevated particulates in the air caused by the smoke from forest fires in 2002, most notably the Biscuit Fire, which began in the Siskiyou National Forest west of Upper Klamath Lake on July 13 and ultimately burned nearly 500,000 acres. The first burst of 10- and 2.5- $\mu \mathrm{m}$ particulates entered the area on July 25, and the particulates remained elevated in concentration through August (U.S. Environmental Protection Agency, 2006). Solar radiation data collected during the same period at the Bureau of Reclamation Agrimet site on Agency Lake does not show a reduction in incident radiation associated with the elevated concentration of particulates in the air, however, so the evidence linking the LDOE between August 2 and August 13, 2002, directly to reduced photosynthetic activity caused by smoke in the air from the Biscuit fire is not conclusive.

In the 3 years of this study, the period when the connection between the bloom decline and the occurrence of a LDOE was most direct was between July 21 and August 2, 2003. This severe LDOE, which culminated in a fish die-off, was coincident with a sharp decrease in chlorophyll $a$ concentrations, indicating that a major decline in the bloom had occurred (fig. 9); the dates estimated to bracket the decline were July 19 and August 1, 2003. Even so, the bloom decline does not appear to be the entire explanation for the LDOE because dissolved oxygen began to trend downward early in July 2003, well before the marked decrease in the weekly chlorophyll $a$ concentrations. This apparent discrepancy suggests that although the bloom decline may have exacerbated and perhaps accelerated the downward trend in dissolved oxygen, a larger set of circumstances also contributed to the event. 
In 2004, an LDOE occurred between August 11 and August 13, which coincides with the estimates of the dates of a bloom decline in that year (fig. 9). This bloom decline was less definitive than in the other 2 years, and the dates were difficult to estimate, but chlorophyll $a$ concentrations on August 11 were very low at sites UKL07 and UKL02 (5.8 $\mu \mathrm{g} / \mathrm{L}$ at UKL07 and $1 \mu \mathrm{g} / \mathrm{L}$ at UKL02, respectively). It seems likely, therefore, that a bloom decline, perhaps more localized than in the other 2 years, accompanied by a reduction in photosynthesis, is part of the explanation for the LDOE during mid-August in 2004.

\section{Wind-Driven Circulation}

Under prevailing wind conditions, the wind-driven circulation moves water northward in the lake through the trench along the western shoreline (fig. 8). The immediate source of water to the study area, therefore, is the cross-section between Bare Island and Eagle Ridge (A-B in fig. 8). Direct observations of the water leaving the trench were made as part of this study starting in 2003, when sites UKL13 and UKL14 were established. Upon leaving the trench, water circulating in the prevailing clockwise direction first passes through site UKL14, then UKL13. Site UKL07, centrally located in the study area, can be considered "downstream" of site UKL13. The traveltime between UKL14 and UKL07 is short-about 1.4 days, on the basis of a current velocity of $5 \mathrm{~cm} / \mathrm{s}$ as representative of the currents measured at ADCP3 (fig. 1).
From these observations, it is apparent that the water that enters the area from the trench often is depleted of dissolved oxygen compared to other parts of the lake (figs. 27 and 28). Under some circumstances there is very little change in the dissolved oxygen concentration of the water as it progresses from sites UKL14 to UKL07, as during the entire month of July 2003 (fig. 27). At other times, however, nonconservative processes alter the dissolved oxygen concentration substantially between the time that the water leaves the trench and when it passes through site UKL07. This was the situation through much of July and August 2004, when concentrations at site UKL07 were consistently higher than those at sites UKL14 and UKL13 by several milligrams per liter (fig. 28). In mid-August in particular, a pulse of water low in dissolved oxygen was observed at sites UKL14 and UKL13, but by the time this pulse of water passed through site UKL07, the dissolved oxygen concentration had increased substantially. Whether nonconservative processes can alter the characteristics of the water leaving the trench substantially as it passes through the study area depends on the actual traveltime, which varies with wind speed and direction, and the intrinsic oxygen-producing and oxygen-consuming capacities of the water. Neither of these can be estimated with the datasets presented in this report, but a better understanding of both in the future may be key to understanding the development of a severe LDOE in the northern part of the lake.

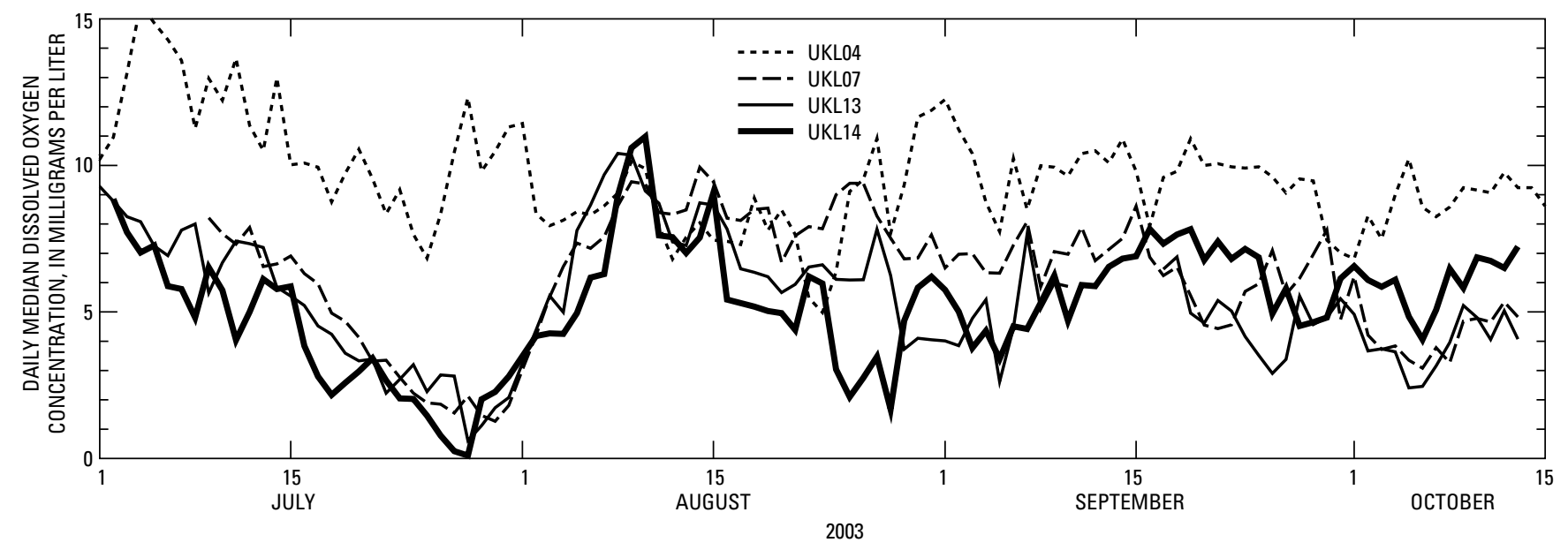

Figure 27. Daily median dissolved oxygen concentrations at sites UKL04, UKL07, UKL13, and UKL14 in Upper Klamath Lake, Oregon, 2003. 


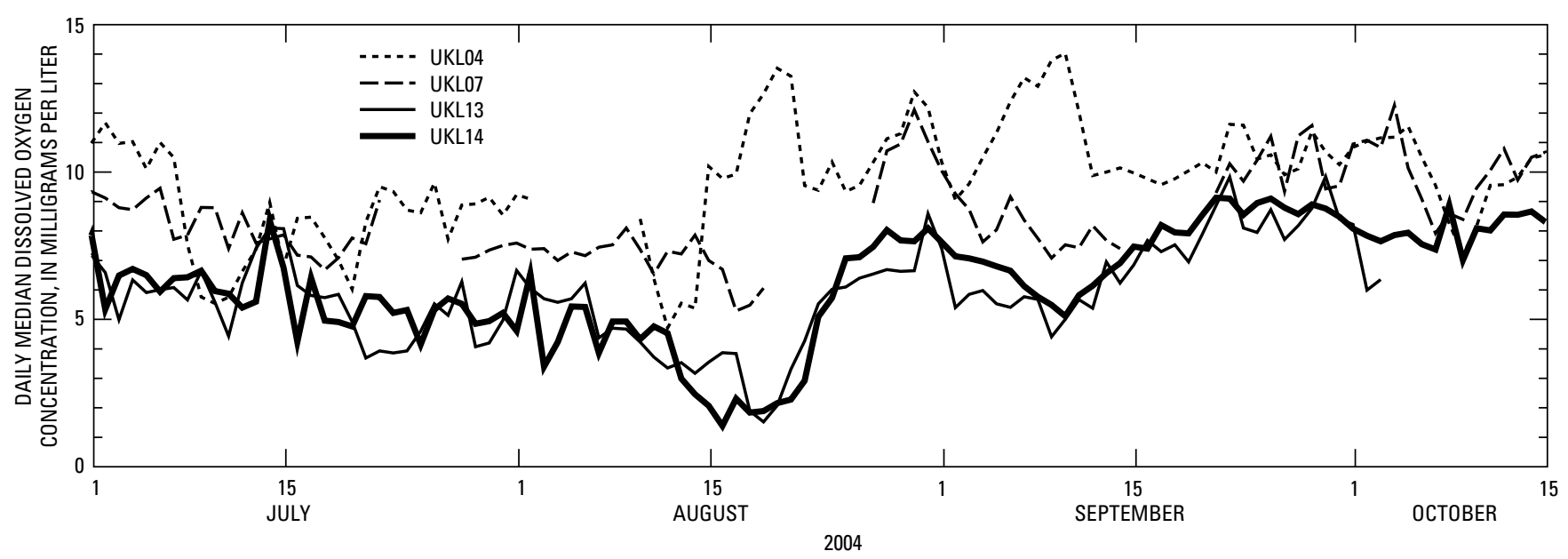

Figure 28. Daily median dissolved oxygen concentrations at sites UKL04, UKL07, UKL13, and UKL14 in Upper Klamath Lake, Oregon, 2004.

The wind-driven circulation must be considered when evaluating the causes of long-term trends (on weekly to monthly time scales) in water quality, such as the steady decrease in dissolved oxygen in July 2003 that culminated in a severe LDOE. Because the wind-driven circulation moves much of the volume of the lake around a closed loop in about 10 days, trends in water quality on time scales that long or longer must be understood as the cumulative effect of nonconservative processes as water moves in its flow path around the lake. A steady decrease in dissolved oxygen, such as was seen in July 2003, therefore, indicates that, when integrated over the entire flow path, the oxygen demands exceeded oxygen production through photosynthesis. Given that is the case, further investigation of oxygen consumption and production rates around the lake, particularly in areas not monitored in this study, will be helpful. It also is important to understand how changes in wind speed and direction are manifested as changes in the wind-driven circulation, and how changes in circulation around the lake interact with the spatially varying oxygen consumption and production rates. Changes in the circulation pattern could be part of the explanation for why severe LDOEs develop in some years but not in others.

Because of the proximity of the trench to the study area, and because it is the immediate source of water to that area, the wind-driven circulation pattern, and in particular short reversals or stalls in that pattern, affect water quality in the study area on the short 1-2-day time scale that represents the residence time in the trench, as well as on longer time scales as discussed above. Passage through the trench results in a net loss of dissolved oxygen in the water column because the depth of the narrow flow through the trench is much greater than the photic zone, and the respiratory and decay processes that consume oxygen over the entire water column overwhelm the photosynthetic production in the photic zone. The magnitude of the loss will depend on the rates of oxygen demanding processes, which vary in space and time. The magnitude of the loss also depends on the traveltime through the trench, which under routine conditions probably is on the order of 1.2 days [based on a GIS estimate of the volume of the trench of $61.6 \mathrm{~m}^{3}$ (T.L. Haluska, U.S. Geological Survey, unpub. data, 2005), and an estimate of the discharge through cross-section $A-B$ (fig. 8) based on synoptic measurements in June 2005 of $580 \mathrm{~m}^{3} / \mathrm{s}$ (R.E. Wellman, U.S. Geological Survey, unpub. data, 2005)].

There are periods lasting from one to several days when the wind reverses and comes from the east to southeast. These periods are seen in the ADCP data as times when the currents, still in alignment with the trench bathymetry, reverse direction (figs. 6 and 7). The effect of these shifts is to reverse or stall the prevailing circulation pattern. One of the consequences of a reversal in the wind, or even a period of lower-than-normal wind stress, is that the traveltime in the trench is increased. Depending on how long the reversal or low-wind period lasts, the increase in traveltime can be substantial. When this happens, oxygen demanding processes have a longer time to act, and the effect on the quality of water in the trench can be substantial. This effect can be seen in the dissolved oxygen data collected at site UKL16, which was located in the midtrench area in 2004 (fig. 29). The hourly dissolved oxygen measurements at site UKL14, which is the first study site encountered by a water parcel leaving the trench heading north, also are shown.

The wind reversed for a day or more nine times during this 3-month record. Nearly every time there was a reversal in the wind, there was a rapid decrease in the dissolved oxygen at site UKL16; sometimes the effect was limited to the 1-m off-the-bottom measurement, and sometimes the effect was 
seen in the mid-water-column measurement as well. The pulse of low dissolved oxygen water through site UKL14 occurred after currents returned to the prevailing direction, delayed by the traveltime between sites UKL16 and UKL14. When the pulse of low dissolved oxygen water passed by site UKL14, it generally was moderated compared to conditions at site UKL16, and it was superimposed on the trends in the data at longer time scales. Sometimes there was no discernible signal at site UKL14, even after a long period of reversal, such as occurred from July 12-18, 2004. During the reversal, the effect at site UKL14 was often to generate widely fluctuating measurements, and sometimes a rapid increase in concentration, as water farther away from the trench (the "downstream" direction under prevailing conditions) was pulled into the site.

In 2003, there was no profiling buoy at the midtrench site, but data were collected at site UKL14 (fig. 30). As in 2004, the immediate effect of the wind reversals was usually an increase in the dissolved oxygen concentration and larger fluctuations, but this was usually followed by a decrease in concentration as the pulse of low dissolved oxygen water from the trench passed by. Between August 5 and August 27, there was a series of reversals that appear to build on each other such that the concentration at site UKL14 decreased a little more with each short event, finally resulting in a period of several days between August 23 and 29 when concentrations fluctuated below $5 \mathrm{mg} / \mathrm{L}$, often dipping below $2 \mathrm{mg} / \mathrm{L}$. The LDOE of 2003 that led to a fish die-off, however, occurred during the last 2 weeks in July, and there were no reversals in the period leading up to it. There was a reversal event between July 24 and 26, which caused concentrations at both sites to approach zero. This effect was superimposed on a longer-term trend, however, that resulted in concentrations in the $2-3 \mathrm{mg} / \mathrm{L}$ range before the reversal occurred, so a wind reversal does not appear to be the sole explanation for the July 2003 LDOE. It does, however, appear to have caused already low dissolved oxygen concentrations to decrease even further.

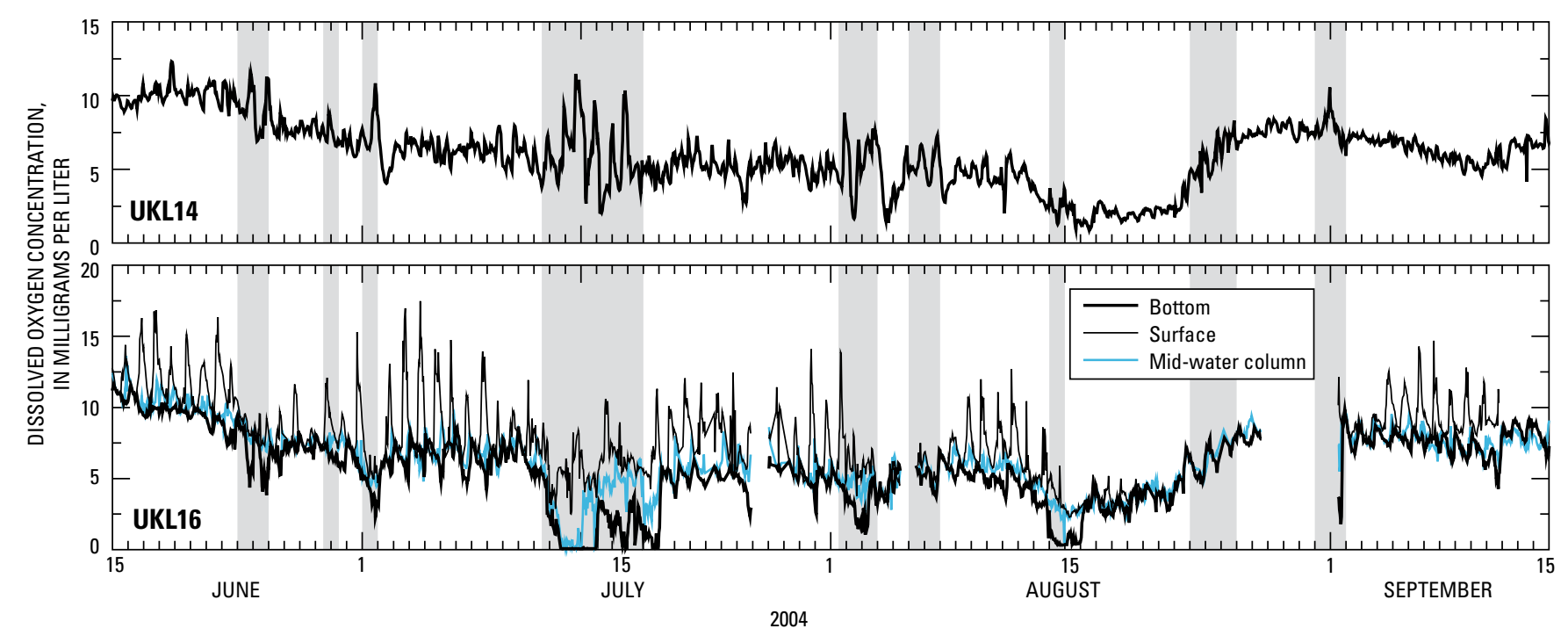

Figure 29. Hourly dissolved oxygen concentrations at sites UKL14 and UKL16 in Upper Klamath Lake, Oregon, 2004. Shaded periods denote current reversals.

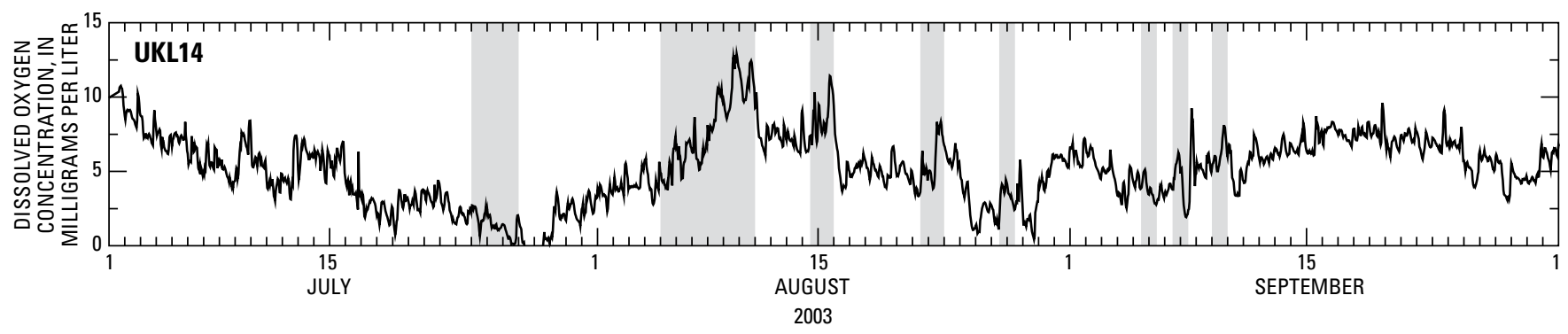

Figure 30. Hourly dissolved oxygen concentrations at site UKL14 in Upper Klamath Lake, Oregon, 2003. Shaded periods denote current reversals. 


\section{Historical Context of 2002-04 Data}

It is of interest to know whether the data collected during the 3 years of this study and the resulting insights into water quality generally are applicable, or whether 2002-04 were in some way extraordinary in a historical context. Equally important, because there was a small fish die-off in 2003, was to investigate whether, in the context of 15 years of data, certain conditions distinguish the years when fish die-offs occurred. In addition to the die-off that occurred in 2003, severe die-offs occurred in 1996 and 1997, and a smaller die-off occurred in 1995. The comparison of the numbers of dead fish collected during die-offs is compromised by the lack of reliable estimates of the effort expended in collecting the fish, so these comparisons should not be considered reliable quantitative measures of the relative severity of the die-offs in the mid-1990s. Nonetheless, based on the number of dead fish collected, the most severe die-offs occurred in 1996 and 1997, and the 1995 die-off was more severe than the 2003 die-off [472 dead suckers were collected in 1995; 4,453 in 1996; 2,335 in 1997 (Perkins and others, 2000)], and 113 in 2003 (B.J. Adams, U.S. Geological Survey, written comm., 2006). It is possible, however, that the low number of fish collected in 2003 reflects the devastating loss to the population caused by the mid-1990s die-offs, and that from a water-quality perspective the 2003 die-off was as severe an event as occurred in the mid-1990s. The die-off in 1995 differed from the other three in that it did not begin until September 1, whereas each of the other three began in July [July 16 in 1996, July 23 in 1997, and July 22 in 2003 (Perkins and others, 2000)]. Because of the need to limit the scope of the analyses, a focus was placed on the July/August time period, and the 1995 fish die-off was not considered.

The datasets that are long enough and of adequate quality for such an investigation are limited, but this discussion makes use of four. The first is the water-quality dataset collected by the Klamath Tribes since 1990. This dataset consists of water samples collected every 2 weeks and analyzed for nutrient and chlorophyll $a$ concentrations, and accompanying water-quality profiles of dissolved oxygen, $\mathrm{pH}$, temperature, and specific conductance. The second dataset is a weather dataset (wind speed and direction, and air temperature ) obtained from the National Climatic Data Center (NCDC, 2006) collected since 1990 at the Klamath Falls airport. Both of these datasets are used to look at a 15-year length of record. The third dataset is a wind dataset collected by the Bureau of Reclamation (1997) at an Agrimet site near Agency Lake; the length of record is only the 5 years since 2000, but the comparison with the NCDC data for that 5-year period is informative. The last dataset is the discharge collected at the Williamson River gaging station maintained by the USGS , 10.3 mi upstream of where the Williamson River discharges into the lake (fig. 1; USGS site identification No. 11502500; U.S. Geological Survey [no date]).

\section{Temperature}

One of the distinguishing characteristics of 2003 was water temperature. The median study-area water temperatures peaked at the end of July in 2003 at $24.9^{\circ} \mathrm{C}$, which was higher than the highest temperatures observed in $2002\left(23.3^{\circ} \mathrm{C}\right)$ or $2004\left(23.5^{\circ} \mathrm{C}\right)$. High water temperatures can contribute to an LDOE by accelerating oxygen demanding processes, and can contribute to a fish die-off by facilitating the spread of disease. Historic water-temperature records are not available, but water temperature is largely a function of air temperature, and so it is logical to look for years that stand out in the air-temperature record. The median air temperature for the months of July and August were determined from hourly values in the NCDC dataset, and subjected to an ANOVA (table 8). Fish die-offs in 1996, 1997, and 2003 began in mid- to late July, although the majority of dead suckers that were collected in 1996 and 1997 were collected later-between August 26 and September 12 in 1996, and between August 20 and September 8 in 1997 (Perkins and others, 2000)—so both July and August temperatures were used in this analysis. The years 1994, 1996, and 2003, although statistically indistinguishable from each other in this analysis, as a group had the highest median air temperature in July of the entire 15-year record. In August, the years 1992, 1996, 1997, 1998, and 2001 ranked as the hottest group of years, while 2003 was cooler. It seems appropriate to conclude that 3 of the 4 fish die-off years were among the warmest years in July and August of the 15-year record.

Table 8. Results of analysis of variance (ANOVA) of air temperature at the Klamath Falls Airport, Oregon, July and August, 1990-2004.

[Medians were calculated from hourly values obtained from the National Climatic Data Center. Years that share a letter are not statistically distinguishable $(p<0.05)$ from each other using this test. Years that do not share a letter are statistically distinguishable $(p<0.05)$ using this test. Abbreviations: ${ }^{\circ} \mathrm{F}$, degree Fahrenheit]

\begin{tabular}{|c|c|c|c|c|c|}
\hline \multicolumn{3}{|c|}{ July } & \multicolumn{3}{|c|}{ August } \\
\hline $\begin{array}{c}\text { Median } \\
\text { temperature } \\
\left({ }^{\circ} \mathrm{F}\right)\end{array}$ & Year & $\begin{array}{c}\text { Tukey } \\
\text { grouping }\end{array}$ & $\begin{array}{c}\text { Median } \\
\text { temperature } \\
\left({ }^{\circ} \mathrm{F}\right)\end{array}$ & Year & $\begin{array}{c}\text { Tukey } \\
\text { grouping }\end{array}$ \\
\hline 73 & 1994 & A & 69 & 1992 & A \\
\hline 72 & 1996 & A & 68 & 1997 & A,B \\
\hline 70 & 2003 & A,B & 68 & 1996 & A,B \\
\hline 70 & 1998 & $\mathrm{~B}, \mathrm{C}$ & 68 & 1998 & A,B \\
\hline 69 & 1991 & $\mathrm{~B}, \mathrm{C}$ & 66 & 2001 & $\mathrm{~A}, \mathrm{~B}, \mathrm{C}$ \\
\hline 70 & 2004 & B,C,D & 66 & 1991 & $\mathrm{~B}, \mathrm{C}$ \\
\hline 70 & 2002 & B,C,D & 64 & 2004 & $\mathrm{~B}, \mathrm{C}$ \\
\hline 68 & 1990 & B,C,D & 66 & 1994 & $\mathrm{C}$ \\
\hline 68 & 1997 & B,C,D & 64 & 2003 & $\mathrm{C}$ \\
\hline 67 & 1992 & C,D & 64 & 2000 & C,D \\
\hline 66 & 1999 & $\mathrm{D}, \mathrm{E}$ & 64 & 1999 & $\mathrm{C}, \mathrm{D}$ \\
\hline 66 & 1995 & $\mathrm{D}, \mathrm{E}$ & 64 & 1995 & $\mathrm{C}, \mathrm{D}$ \\
\hline 64 & 2001 & $\mathrm{E}, \mathrm{F}$ & 62 & 1993 & $\mathrm{D}$ \\
\hline 63 & 2000 & $\mathrm{~F}$ & 63 & 2002 & D \\
\hline 60 & 1993 & $\mathrm{G}$ & 61 & 1990 & $\mathrm{D}$ \\
\hline
\end{tabular}




\section{Wind Speed and Direction}

An ANOVA also was done on the wind-speed data collected at the Klamath Falls Airport (table 9). Because of the way wind speeds are distributed throughout the day, peaking for a relatively brief period but being much lower over the rest of the day, it was difficult to see important differences by looking at the entire distributions, which were dominated by the lowest wind speeds. Under the assumption that it is the peak wind speeds that are most important, only wind speeds that exceeded 50 percent of the distribution for the entire month were extracted for this analysis. In July, the years 1996 and 1997 ranked as the lowest wind speed group of the 15-year dataset; 2003 ranked slightly higher. In August, all 3 die-off years ranked higher than they did in July; 1996 and 2003 ranked in the second lowest group, but 1997 ranked in the middle of the 15-year record. Low July and August wind speed, therefore, seems to be a distinguishing characteristic of fish die-off years.

Because short-term wind reversals were observed to cause oxygen concentration to decrease in the study area, an attempt was made to identify years in which wind reversals

Table 9. Results of analysis of variance (ANOVA) of wind speed at the Klamath Falls Airport, Oregon, July and August, 1990-2004.

[Medians were calculated from hourly values obtained from the National Climatic Data Center after first selecting those that fell in the upper one-half of the distribution for the month, as determined by combining all 15 years of the record. Years that share a letter are not statistically distinguishable $(p<0.05)$ from each other using this test. Years that do not share a letter are statistically distinguishable $(p<0.05)$ using this test. Abbreviations: m/s, meter per second]

\begin{tabular}{ccccccc}
\hline & July & & & \multicolumn{3}{c}{ August } \\
\cline { 1 - 3 } $\begin{array}{c}\text { Median } \\
\text { wind } \\
\text { speed } \\
\text { (m/s) }\end{array}$ & Year & $\begin{array}{c}\text { Tukey } \\
\text { grouping }\end{array}$ & & $\begin{array}{c}\text { Median } \\
\text { wind } \\
\text { speed } \\
\text { (m/s) }\end{array}$ & Year & $\begin{array}{c}\text { Tukey } \\
\text { grouping }\end{array}$ \\
\hline 4.9 & & & & \\
4.9 & 1993 & A,B & & 4.5 & 1993 & A \\
4.5 & 1994 & A,B & & 2001 & A \\
4.5 & 1992 & B & & 1994 & B \\
4.5 & 1991 & B & & 4.5 & 1991 & B,C \\
4.5 & 1990 & B & & 3.6 & 1997 & B,C \\
4 & 1995 & C & & 3.6 & 1995 & B,C,D \\
3.6 & 2000 & C,D & 3.6 & 2000 & C,D,E \\
3.6 & 2004 & D,E & 3.6 & 1990 & C,D,E,F \\
3.6 & 1999 & E & 3.6 & 2003 & D,E,F,G \\
3.6 & 2002 & E & 3.6 & 2004 & D,E,F,G \\
3.6 & 1998 & E & 3.6 & 2002 & E,F,G \\
3.1 & 2003 & E & 3.1 & 1996 & F,G \\
2.7 & 1997 & F & 3.1 & 1999 & G \\
2.7 & 1996 & G & 2.2 & 1998 & H \\
\hline
\end{tabular}

might have been relatively numerous compared to other years, thus increasing the average traveltime in the trench. To do this, the vector wind data from the NCDC were projected onto a set of axes rotated $60^{\circ}$ clockwise, such that one axis was aligned along the length of the lake. The resulting "alonglake" component of the wind is positive for a northwest wind. An ANOVA was performed on this component of the wind (table 10). The analysis shows clearly the reversals in August of 2003, as evidenced by a slightly negative alonglake component, but these reversals occurred after the peak of the July LDOE that precipitated the fish die-off. August 1997 also had a slightly negative median along-lake component, indicating that there were several wind reversals in August of that year, when the wind speed was moderate. Three die-off years-1996, 1997, and 2003-rank in the middle of the 15-year record in the magnitude of the July along-lake component, indicating that the number of reversals in July of those years was not exceptional compared to the entire 15-year record. Fish die-off years were not, therefore, characterized by a higher-than-average number of wind reversals in July or August.

Table 10. Results of analysis of variance (ANOVA) of the along-lake component of wind speed at the Klamath Falls Airport, Oregon, July and August, 1990-2004.

[Medians were calculated from hourly values obtained from the National Climatic Data Center after first selecting those that fell in the upper one-half of the distribution for the month, as determined by combining all 15 years of the record. The along-lake component was obtained by projecting the vector data onto a set of axes rotated $60^{\circ}$ clockwise. Years that share a letter are not statistically distinguishable $(p<0.05)$ from each other using this test. Years that do not share a letter are statistically distinguishable $(p<0.05)$ using this test. Abbreviations: $\mathrm{m} / \mathrm{s}$, meter per second]

\begin{tabular}{|c|c|c|c|c|c|}
\hline \multicolumn{3}{|c|}{ July } & \multicolumn{3}{|c|}{ August } \\
\hline $\begin{array}{c}\text { Median } \\
\text { wind } \\
\text { speed } \\
\text { (m/s) }\end{array}$ & Year & $\begin{array}{c}\text { Tukey } \\
\text { grouping }\end{array}$ & $\begin{array}{c}\text { Median } \\
\text { wind } \\
\text { speed } \\
(\mathrm{m} / \mathrm{s})\end{array}$ & Year & $\begin{array}{c}\text { Tukey } \\
\text { grouping }\end{array}$ \\
\hline 4.2 & 2001 & A & 2.7 & 2002 & A \\
\hline 4 & 1994 & $A, B$ & 3.4 & 1993 & $\mathrm{~A}, \mathrm{~B}$ \\
\hline 3.8 & 1993 & $\mathrm{~A}, \mathrm{~B}$ & 2.9 & 2001 & $\mathrm{~A}, \mathrm{~B}, \mathrm{C}$ \\
\hline 3.8 & 1991 & $\mathrm{~A}, \mathrm{~B}, \mathrm{C}$ & 2.5 & 1992 & $\mathrm{~A}, \mathrm{~B}, \mathrm{C}$ \\
\hline 3.5 & 1992 & $\mathrm{~B}, \mathrm{C}$ & 2.4 & 2000 & $\mathrm{~B}, \mathrm{C}, \mathrm{D}$ \\
\hline 3.4 & 1990 & $\mathrm{C}, \mathrm{D}$ & 2.5 & 1995 & $\mathrm{~B}, \mathrm{C}, \mathrm{D}$ \\
\hline 2.5 & 2002 & $\mathrm{D}, \mathrm{E}$ & 2.3 & 1999 & $\mathrm{C}, \mathrm{D}, \mathrm{E}$ \\
\hline 2.2 & 2003 & $\mathrm{E}, \mathrm{F}$ & 2.2 & 1996 & $\mathrm{C}, \mathrm{D}, \mathrm{E}$ \\
\hline 2.1 & 2000 & E.F & 1.8 & 1994 & $\mathrm{D}, \mathrm{E}, \mathrm{F}$ \\
\hline 2.2 & 1996 & $\mathrm{~F}, \mathrm{G}$ & 1.2 & 1998 & $\mathrm{E}, \mathrm{F}, \mathrm{G}$ \\
\hline 2 & 1999 & $\mathrm{~F}, \mathrm{G}$ & 1.2 & 2004 & $\mathrm{E}, \mathrm{F}, \mathrm{G}$ \\
\hline 2 & 1997 & $\mathrm{~F}, \mathrm{G}$ & 1.3 & 1990 & $\mathrm{~F}, \mathrm{G}$ \\
\hline 1.7 & 1995 & $\mathrm{~F}, \mathrm{G}$ & .9 & 1991 & $\mathrm{G}$ \\
\hline 1.4 & 2004 & $\mathrm{~F}, \mathrm{G}$ & .9 & 1997 & $\mathrm{G}, \mathrm{H}$ \\
\hline 1.6 & 1998 & $\mathrm{G}$ & -1.3 & 2003 & $\mathrm{H}$ \\
\hline
\end{tabular}


There were indications that the NCDC wind dataset was not ideally suited to highly quantitative analysis. There was clear evidence, for example, of "binning" in the NCDC wind dataset_-values always fell on discrete values rather than being continuous. In addition, wind speeds of zero were numerous, so it is likely that all values below a threshold became zero. As a means of assessing the quality of the data and the confidence one should have in the ANOVA analysis, an analysis of only 2000-04 data was compared for consistency to the same analysis for those 5 years of wind data collected at the Agency Lake Agrimet site (table 11). Among other discrepancies, the year 2003 ranks in the lowest wind speed group in the NCDC data, but ranks second highest in the Agrimet data. The relative ranking among the 2002, 2003, and 2004 wind datasets collected at the profiling buoys in this study are consistent with the Agrimet data but not the NCDC data, the 2003 July wind data being the highest of the three. The significance of this comparison is that the NCDC wind data probably should be interpreted qualitatively. It is appropriate, for example, to conclude that wind speed in the years 1996, 1997, and 2003 ranks toward the low end of the entire 15-year period, but the quantitative differences between any pair of years is not reliable, and the characterization of 2003 as a very low wind speed year should be viewed skeptically because it is inconsistent with data collected over the 3 years of this study, and with the 5 years of Agrimet data.

Table 11. Results of analysis of variance (ANOVA) of wind speed at the Klamath Falls Airport and at the Bureau of Reclamation Agrimet site located at Agency Lake, Oregon, July and August, 1990-2004.

[Medians were calculated from hourly values obtained from the National Climatic Data Center (NCDC) after first selecting those that fell in the upper one-half of the distribution for the month, as determined by combining all 15 years of the record. Medians at the Agency Lake Agrimet site were calculated from hourly values that fell in the upper one-half of the distribution for the month, as determined by combining 5 years of the record from 2000 to 2004. Years that share a letter are not statistically distinguishable $(p<0.05)$ from each other using this test. Years that do not share a letter are statistically distinguishable $(p<0.05)$ using this test. Abbreviations: m/s, meter per second]

\begin{tabular}{ccccccc}
\hline & NCDC & & \multicolumn{3}{c}{ AGRIMET } \\
\cline { 1 - 3 } $\begin{array}{c}\text { Median } \\
\text { wind } \\
\text { speed } \\
\text { (m/s) }\end{array}$ & Year & $\begin{array}{c}\text { Tukey } \\
\text { grouping }\end{array}$ & & $\begin{array}{c}\text { Median } \\
\text { wind } \\
\text { speed } \\
\text { (m/s) }\end{array}$ & Year & $\begin{array}{c}\text { Tukey } \\
\text { grouping }\end{array}$ \\
\hline 4.9 & 2001 & $\mathrm{~A}$ & 2.2 & 2000 & $\mathrm{~A}$ \\
3.6 & 2000 & $\mathrm{~B}$ & & 1.9 & 2003 & $\mathrm{~B}$ \\
3.6 & 2004 & $\mathrm{~B}, \mathrm{C}$ & & 1.8 & 2001 & $\mathrm{C}$ \\
3.6 & 2002 & $\mathrm{C}$ & & 1.8 & 2002 & $\mathrm{C}$ \\
3.1 & 2003 & $\mathrm{C}$ & 1.5 & 2004 & $\mathrm{D}$ \\
\hline
\end{tabular}

\section{Lake-Wide Water Quality}

An ANOVA similar to that used to rank the wind and air temperature datasets was used to rank the years of the 15-year water quality dataset collected by the Klamath Tribes (fig. 31). Only data from seven lake sites that were consistent through 1990-2004 were used in the analysis. The variability between sites and within a 2-month time frame largely swamps interyear variability in chlorophyll $a$ and dissolved oxygen, making the distributions nearly indistinguishable from each on a yearly basis. This type of aggregate analysis over several sites and the entire July-August time frame averages out important distinctions, and no characteristics emerge to distinguish the fish die-off years of 1995, 1996, 1997, and 2003. Attempts to relate the Klamath Tribes waterquality variables to NCDC wind speed over the 15 years of record available in both datasets yielded nonsignificant relations as well (fig. 32), in spite of the fact that significant correlations were obtained by others on a shorter period of record (Kann and Welch, 2005).

In contrast to chlorophyll $a$ and the other nutrients, large multiyear trends in the distribution of the July-August ammonia concentration have been observed over the 15-year record; these multiyear trends strongly suggest that climatic factors are involved. In order to test this, correlations were calculated among two climate variables, July-August NCDC wind speed and the October-May cumulative discharge in the Williamson River, May-June and July-August median values of ammonia and chlorophyll $a$ concentration, and the median of the difference between the water column maximum and minimum dissolved oxygen (denoted $\Delta$ dissolved oxygen) (table 12). July-August median chlorophyll $a$ concentration and $\Delta$ dissolved oxygen were not correlated with either climate variable, indicating that year-to-year variability in these variables is not climate-driven. Nor are year-toyear changes in chlorophyll $a$ concentration, ammonia concentration, or $\Delta$ dissolved oxygen correlated with each other. July-August median ammonia concentrations were, however, highly correlated with both climate variables, confirming that the interannual variability in ammonia probably is climate related. Because the two climate variables-July-August wind speeds and discharge from the Williamson River for the previous October-May-are themselves correlated, it could be difficult to sort out which, if either of these, represents a causal relation. Because, however, the July-August wind speed median also was correlated with the ammonia concentration in the previous months of May and June, it is more likely that the correlation between ammonia and Williamson River discharge represents some kind of causal relation. 

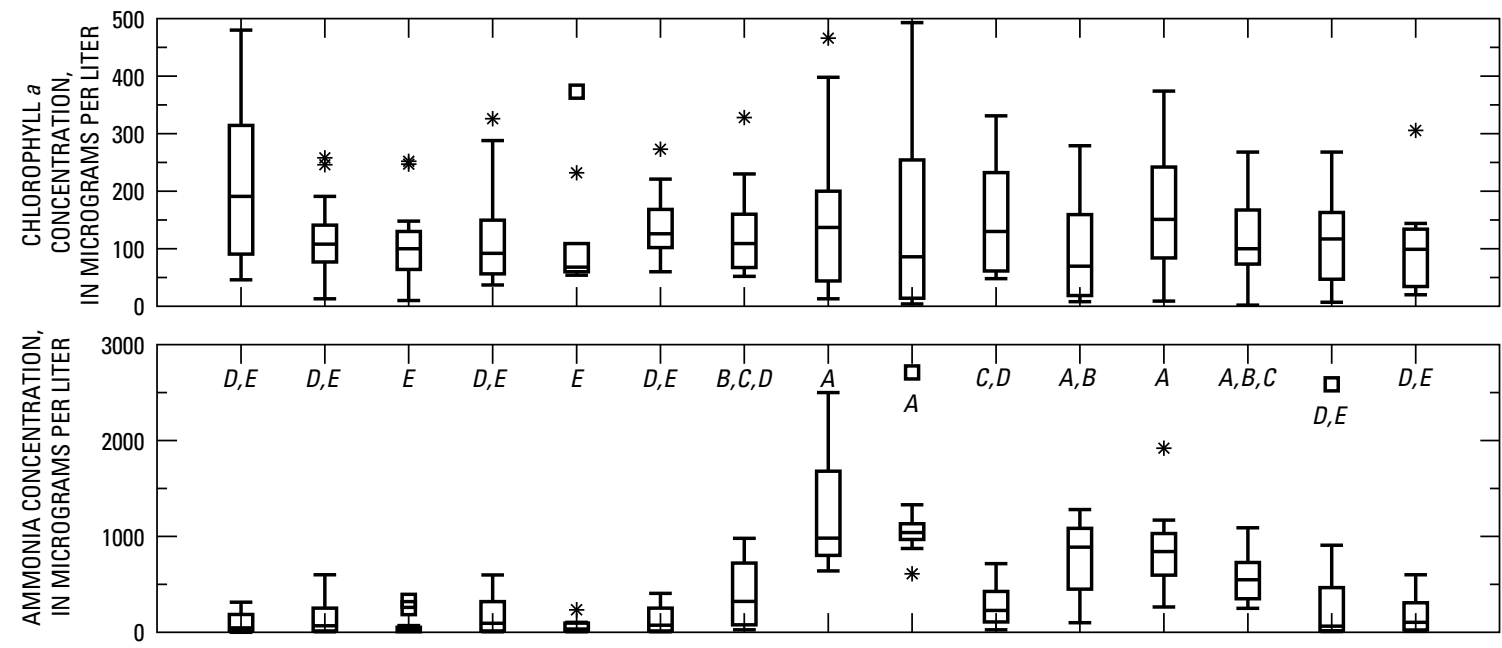

EXPLANATION
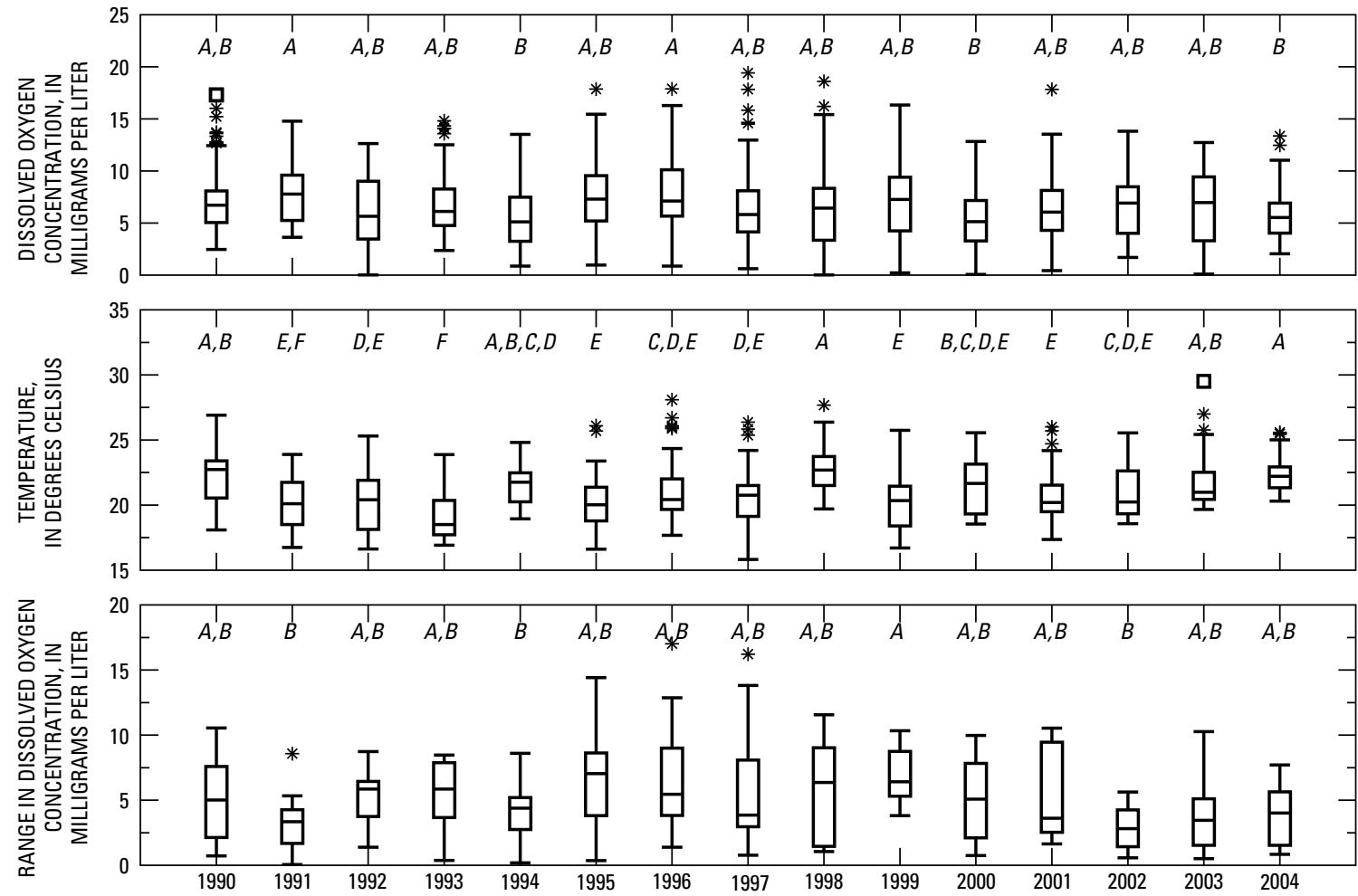

Figure 31. July-August distributions of concentrations of chlorophyll a, ammonia, dissolved oxygen, and temperature, and the difference between the water column maximum and minimum dissolved oxygen, at three sites located in Upper Klamath Lake, Oregon. Data collected biweekly by the Klamath Tribes (K. Fischer, written commun., 2005). Years that share a letter are not statistically distinguishable $(p<0.05)$ from each other using this test. Years that do not share a letter are statistically distinguishable $(p<0.05)$ using this test. There were no significant differences in the yearly distributions of chlorophyll $a$.

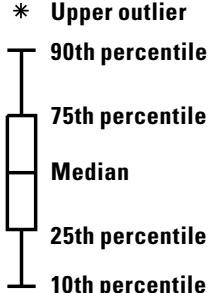


Table 12. Spearman's rho correlation coefficients between selected water-quality and climate variables in Upper Klamath Lake Basin, Oregon, 1990-2004.

[Water-quality data are biweekly values of chlorophyll $a$ and nutrient concentrations, and biweekly profiles of dissolved oxygen concentration collected by the Klamath Tribes at seven sites in Upper Klamath Lake. Means at the Klamath Falls Airport were calculated from hourly values obtained from the National Climatic Data Center (NCDC) after first selecting those that fell in the upper one-half of the distribution for the month, as determined by combining 15 years of the record from 1990 to 2004. Correlations that are significant $(p<0.05)$ are in boldface type. Median July-Aug. $\Delta$ DO: median difference between water column maximum and minimum dissolved oxygen concentration. Mean July-Aug. wind speed: mean of July and August wind speed at the Klamath Falls Airport. Cumulative Oct.-May discharge: discharge at U.S. Geological Survey station 11502500 from October of the previous calendar year through May of the current year. Symbols: <, less than]

\begin{tabular}{|c|c|c|c|c|c|c|c|}
\hline \multirow{3}{*}{ Concentrations } & \multicolumn{7}{|c|}{ Spearman's rho correlation coefficient } \\
\hline & \multicolumn{5}{|c|}{ Concentrations } & \multirow[b]{2}{*}{$\begin{array}{l}\text { Mean } \\
\text { July-Aug. } \\
\text { wind speed }\end{array}$} & \multirow{2}{*}{$\begin{array}{c}\text { Cumulative } \\
\text { Oct.-May } \\
\text { Williamson River } \\
\text { discharge }\end{array}$} \\
\hline & $\begin{array}{c}\text { Median } \\
\text { July-Aug. } \\
\text { chlorophyll a }\end{array}$ & $\begin{array}{c}\text { Median } \\
\text { May-June } \\
\text { chlorophyll a }\end{array}$ & $\begin{array}{l}\text { Median } \\
\text { July-Aug. } \\
\text { ammonia }\end{array}$ & $\begin{array}{l}\text { Median } \\
\text { May-June } \\
\text { ammonia }\end{array}$ & $\begin{array}{l}\text { Median } \\
\text { July-Aug. } \\
\quad \Delta \text { DO }\end{array}$ & & \\
\hline $\begin{array}{l}\text { Median July-Aug. } \\
\text { chlorophyll } a\end{array}$ & 1.00 & -0.32 & 0.00 & 0.23 & -0.10 & -0.08 & 0.11 \\
\hline $\begin{array}{l}\text { Median May-June } \\
\text { chlorophyll } a\end{array}$ & & 1.00 & .12 & .24 & .15 & .33 & -.32 \\
\hline $\begin{array}{l}\text { Median July-Aug. } \\
\text { ammonia }\end{array}$ & & & 1.00 & .81 & -.01 & -.52 & .75 \\
\hline $\begin{array}{l}\text { Median May-June } \\
\text { ammonia }\end{array}$ & & & & 1.00 & -.10 & -.54 & .52 \\
\hline $\begin{array}{l}\text { Median Jul-Aug } \\
\quad \Delta \mathrm{DO}\end{array}$ & & & & & 1.00 & -.14 & .32 \\
\hline $\begin{array}{l}\text { Mean July-Aug. } \\
\text { wind speed }\end{array}$ & & & & & & 1.00 & -.71 \\
\hline $\begin{array}{l}\text { Cumulative Oct.-May } \\
\text { Williamson River } \\
\text { discharge }\end{array}$ & & & & & & & 1.00 \\
\hline
\end{tabular}

A straightforward explanation for this relation would be that higher discharge from the Williamson River during the winter and spring delivers more organic material that acts as a source of ammonia when it decays in the summer. Although the climate connection to ammonia appears solid, ammonia concentration alone is not a predictor of fish die-off years.
Concentrations in 1997 were among the highest on record, but other years had similarly high concentrations. Concentrations in 1996 were in the midrange, and concentrations in 2003 were among the lowest of the record, comparable to the early 1990s. 

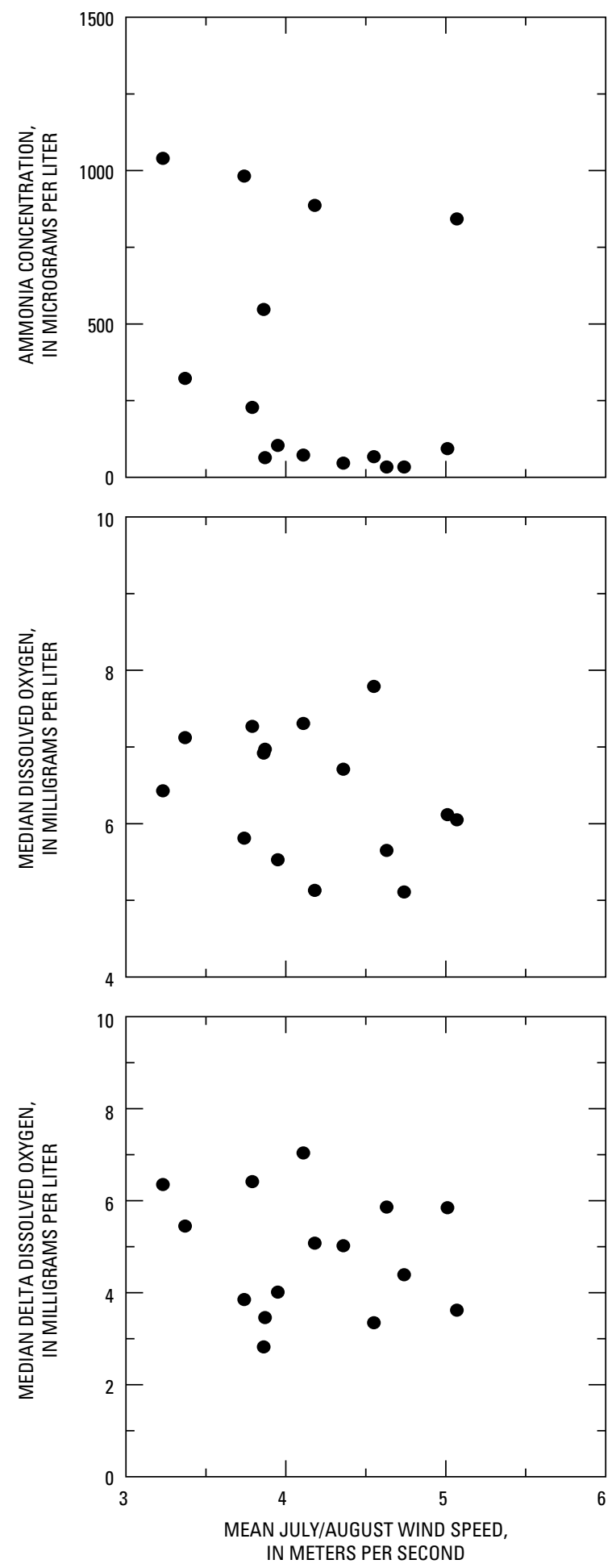

Figure 32. Correlation between the July-August averaged wind speed at the Klamath Falls Airport and the median of the July-August distribution of ammonia, dissolved oxygen, and the difference between water column maximum and minimum dissolved oxygen, Upper Klamath Lake, Oregon. Wind data are from the National Climatic Data Center (2006), and the means are calculated on only the upper 50 percent of the distribution. Ammonia and dissolved oxygen data were obtained from the Klamath Tribes.

\section{Water Quality at Indicator Sites}

The aggregate analysis of the Klamath Tribes' dataset based on July-August distributions at the sites in the northern part of the lake did not yield an obvious way of identifying the fish die-off years in the 15-year record. Another approach taken was to focus on individual sites and test the idea of an "indicator site" - a particular site that could be reliably used to indicate the onset of an LDOE in the study area. Because the water quality in the study area is largely a function of the quality of the water entering the study area through the trench between Bare Island and Eagle Ridge, the onset of an extreme event should be accompanied by the transport of a large volume of water with a low concentration of dissolved oxygen through the trench. One of the Klamath Tribes' sampling sites is located in the area of the trench between Bare Island and Eagle Ridge; this site is known as Eagle Point, or EP. Another site located roughly between the 2003-04 UKL06 and UKL07 sites is Midnorth, or MN (fig. 1). The latter site is, like UKL 07, broadly representative of the conditions in the deeper part of the study area that is preferred habitat for adult suckers and is bounded by the remnants of the trench and the entrances to Ball and Shoalwater Bays to the south. Data from these two sites were used in a principal component (PC) analysis to test the "indicator site" idea.

Seven variables were included in the PC analysischlorophyll $a$ concentration, ammonia concentration, average water column dissolved oxygen concentration, minimum water column dissolved oxygen concentration, the difference between maximum and minimum water column dissolved oxygen concentration, maximum water column temperature, and the difference between maximum and minimum water column temperature. At site $\mathrm{MN}$, the first three eigenvalues were able to explain 36,28 , and 12 percent of the total variance, respectively; at site ER the first three eigenvalues were able to explain 39, 31, and 14 percent of the total variance, respectively. The loadings of the first three principal components on each variable are given in table 13, and the scores on each July-August sample date are shown in figures 33 and 34 . The first principal component at each site largely captures variability in average water column dissolved oxygen concentration and chlorophyll $a$ concentration, fluctuating opposite to water temperature and ammonia, although the contribution from variability in ammonia is relatively small. The second principal component captures primarily the variability in the water column stratification, and the third principal component is dominated by the variability in ammonia concentration.

The sample date July 28, 2003, has the largest negative PC1 score, reflecting a low average water column dissolved oxygen concentration and low chlorophyll $a$ concentration, in combination with high water temperature and relatively high ammonia concentration. In this analysis, July 2003 appears unique in the context of a 15-year record. The 1996 and 
Table 13. Principal component scores at sites Eagle Ridge and Midnorth in Upper Klamath Lake, Oregon.

\begin{abstract}
[Water-quality data are biweekly values of chlorophyll $a$ and nutrient concentrations, and biweekly profiles of dissolved oxygen concentration collected by the Klamath Tribes at two sites in Upper Klamath Lake during July and August, 1990-2004. Concentrations: $\Delta$ DO: difference between water column maximum and minimum dissolved oxygen concentration. Water column temperature: $\Delta \mathbf{T}$, difference between maximum and minimum water column temperature]
\end{abstract}

\begin{tabular}{|c|c|c|c|c|c|c|c|}
\hline \multirow{3}{*}{$\begin{array}{l}\text { Principal } \\
\text { component }\end{array}$} & \multicolumn{5}{|c|}{ Concentrations } & \multirow{2}{*}{\multicolumn{2}{|c|}{ Water column temperature }} \\
\hline & \multirow{2}{*}{ Chlorophyll a } & \multirow{2}{*}{ Ammonia-N } & \multicolumn{3}{|c|}{ Dissolved oxygen } & & \\
\hline & & & Mean & Minimum & $\Delta \mathrm{DO}$ & Maximum & $\Delta \mathrm{T}$ \\
\hline \multicolumn{8}{|c|}{ Principal component score at Eagle Ridge } \\
\hline 1 & 0.32 & -0.16 & 0.56 & 0.58 & -0.19 & -0.42 & -0.07 \\
\hline 2 & .4 & -.06 & .19 & .04 & .59 & .28 & .61 \\
\hline 3 & .2 & .97 & .07 & .08 & -.05 & .04 & -.03 \\
\hline \multicolumn{8}{|c|}{ Principal component score at Midnorth } \\
\hline 1 & 0.32 & -0.36 & 0.6 & 0.48 & 0.27 & -0.17 & 0.28 \\
\hline 2 & .22 & .07 & -.1 & -.39 & .53 & .5 & .5 \\
\hline 3 & .63 & .74 & .03 & .08 & -.06 & -.2 & -.04 \\
\hline
\end{tabular}

1997 points that have a relatively high PC2 score and stand out from the cloud of other data points are from late July, reflecting the exceptional stratification during that time period. This characteristic of those 2 years has been documented by others (Perkins and others, 2000; Kann and Welch, 2005) in the context of a shorter length of record; in this analysis the exceptional stratification in those years stands out in the context of a longer 15-year record.

In this analysis, the fish die-off years do not group together in obvious separation from the other years on record. This suggests that 2003 does not have a lot in common, in terms of the variables included in this analysis and their correlations, with the other 2 fish die-off years, 1996 and 1997. There are two possible reasons for this. The first is that the years really were different in important ways, and that there is more than one set of circumstances that lead to a fish die-off. The second is that the two-week interval of the sample dates resulted in the most relevant conditions of 1996 and 1997, immediately preceding the die-off, being missed.

The statistics of the distribution of dissolved oxygen, ammonia, and chlorophyll $a$ concentrations, and water temperature for the entire July and August time period were compiled separately for sites ER and MN in tables 14 and $\underline{15}$, respectively. The values of these variables on the sample dates most closely associated with the onset of the fish dieoffs in 1996, 1997, and 2003 also are compiled in the tables. Samples were collected on July 28, 2003, at the peak of the low dissolved oxygen event. The description of this period as characterized by very low dissolved oxygen concentrations in combination with very high ammonia concentrations, as well as high temperatures and low chlorophyll $a$, reappears in this analysis. At both sites, dissolved oxygen and chlorophyll $a$ fall within the first quartile, and ammonia and temperature fall within the fourth quartile, of all sample dates for the JulyAugust period in the 15 years of data.

Data collected on the 1996 and 1997 sampling dates are more difficult to interpret because there are no continuous datasets with which to identify when the worst conditions actually occurred. These sample dates probably missed the time period of lowest dissolved oxygen at site ER. Nonetheless, the August 20, 1996 and August 12, 1997 values at site $\mathrm{MN}$ generally are consistent with a low dissolved oxygen/high temperature/low chlorophyll $a$ /high ammonia combination, with the exception that the temperature fell in the third rather than fourth quartile. Consistent among all fish die-off dates at site $\mathrm{MN}$ is the combination of average water column dissolved oxygen concentration and chlorophyll $a$ concentration in the first quartile (less than $6 \mathrm{mg} / \mathrm{L}$ and less than $65 \mu \mathrm{g} / \mathrm{L}$, respectively) and ammonia concentration in the fourth quartile (greater than $520 \mu \mathrm{g} / \mathrm{L}$ ). If these same criteria are used to screen data collected at site MN during all JulyAugust sample dates in the 15-year dataset, then only four additional dates (out of a total of 71 dates) pass the screening, from 3 non-die-off years: August 12, 1998; August 9 and 22, 2000; and August 29, 2001. It appears, therefore, that there is some validity to screening for die-off conditions based on these criteria at only site MN. These screening criteria offer no predictive capability, of course; their utility is in being able to better describe the set of conditions that appear to have a greater risk of leading to a die-off, and they point to some commonality among the die-off years. 

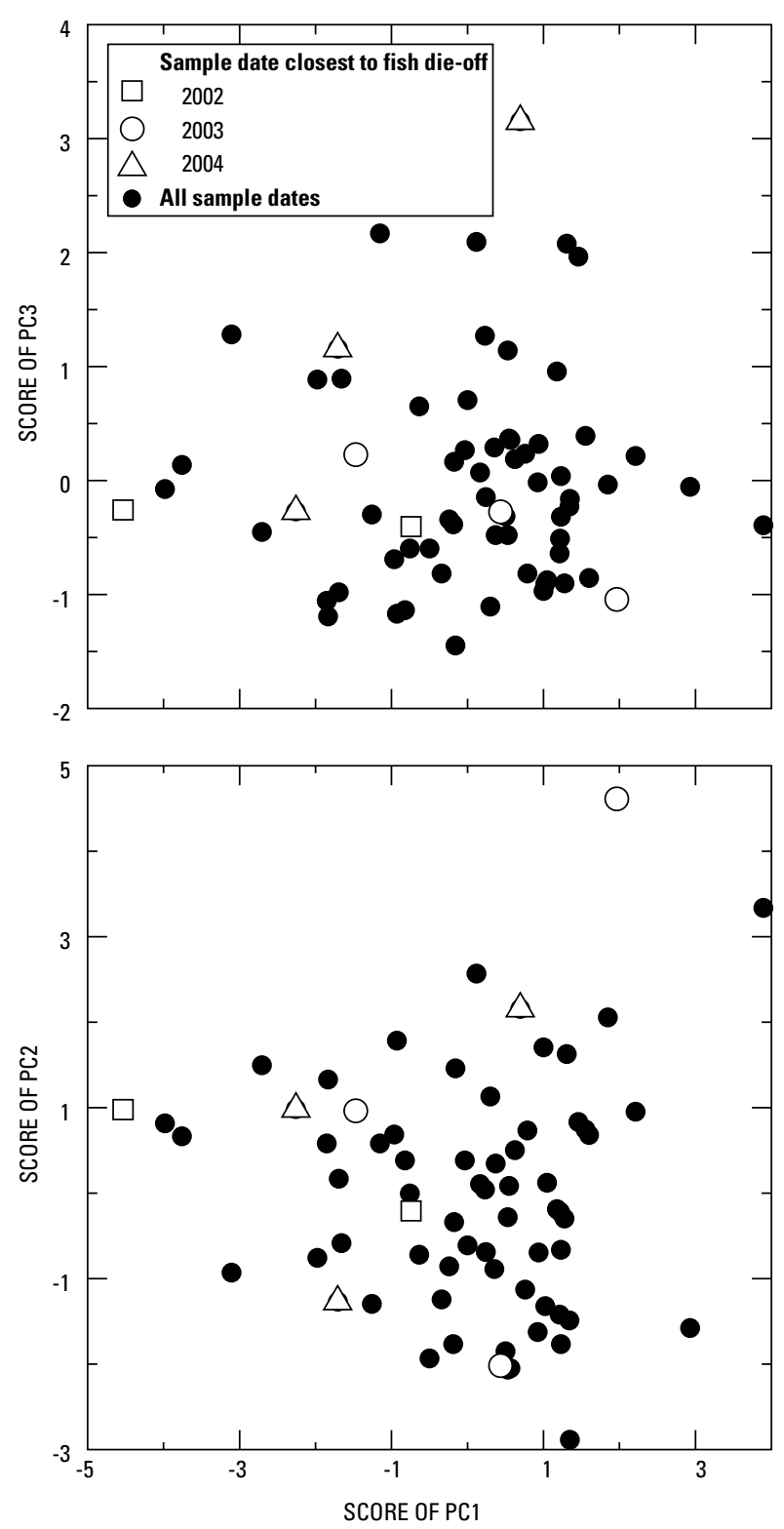

Figure 33. Principal component scores for data from Midnorth site, all July and August sample dates, Upper Klamath Lake, Oregon, 1990-2004. Data were obtained from the Klamath Tribes (K. Fischer, written commun., 2005).

\section{Conclusions Regarding Characteristics of Fish Die-Off Years}

The evidence for a correspondence between low wind speeds and fish die-off years is compelling; all 3 years -1996 , 1997, and 2003 — stand out in the historical record has having lower-than-average July wind speeds. The connection that has been made between low wind speeds and fish die-off years is increased density stratification and the low dissolved oxygen
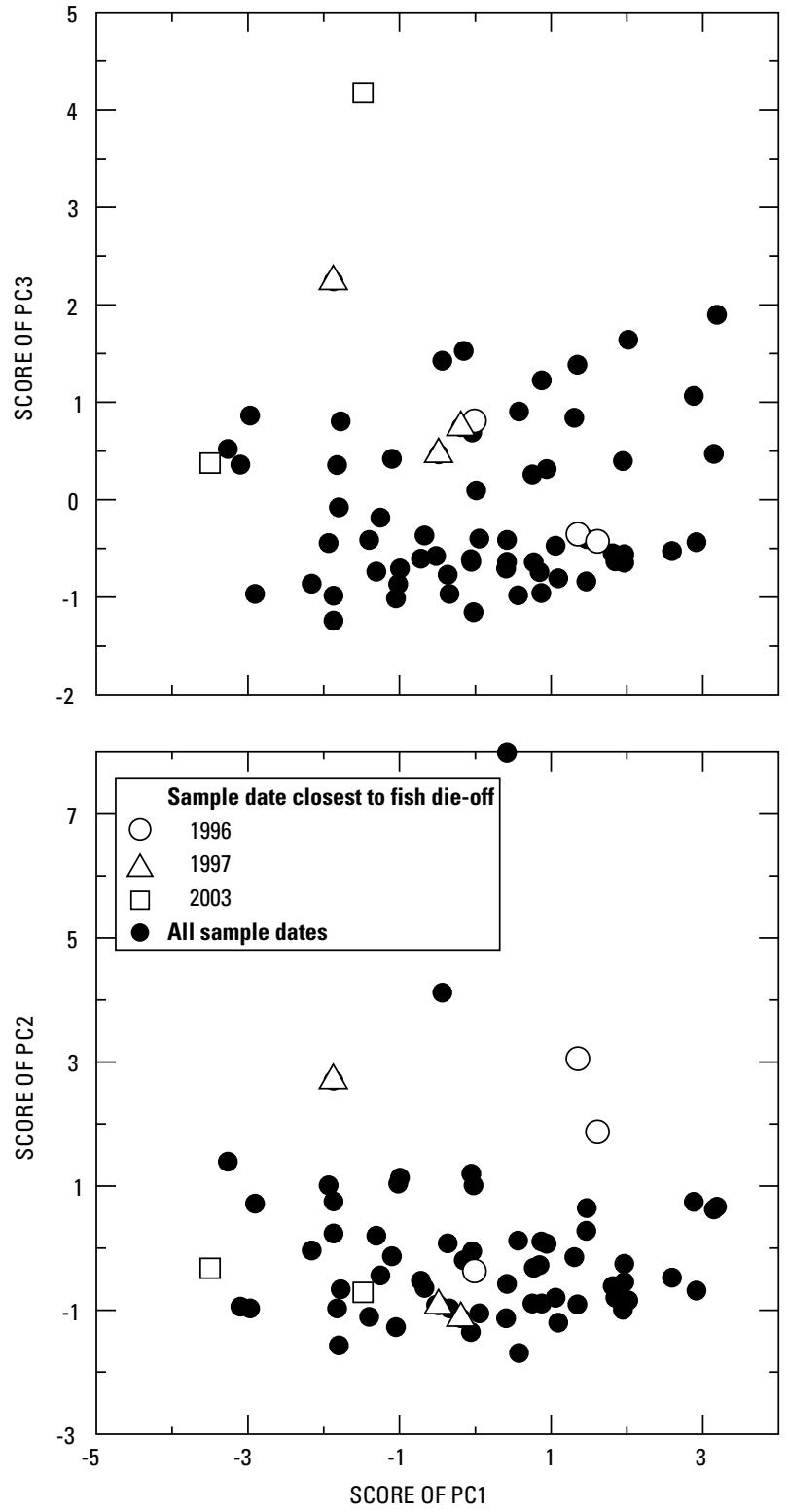

Figure 34. Principal component scores for data from Eagle Ridge site, all July and August sample dates, Upper Klamath Lake, Oregon, 1990-2004. Data were obtained from the Klamath Tribes (K. Fischer, written commun., 2005).

in the lower water column that often accompanies it. Yet, low wind speeds did not correlate well with high dissolved oxygen stratification on either a daily basis within a single year or on the basis of a 2-month average over 15 years of data, nor were all fish die-off years characterized by exceptional dissolved oxygen stratification. Furthermore, strong dissolved oxygen stratification in the water column was not directly the cause of the recent, more well-documented, fish die-offs. This was noted by Perkins and others (2000) regarding fish die-offs in 1996 and 1997, when the great majority of dead suckers were 
Table 14. Distribution statistics of water column averages of chlorophyll $a$, ammonia- $\mathrm{N}$, dissolved oxygen, and temperature at Eagle Ridge site, based on July-August sampling dates, Upper Klamath Lake, Oregon, 1990-2004.

[Water-quality data are biweekly values of chlorophyll $a$ and nutrients, and biweekly profiles of dissolved oxygen collected by the Klamath Tribes at Eagle Ridge in Upper Klamath Lake during July and August 1990-2004. Quartile: Q1, first quartile; Q2, second quartile; Q3, third quartile; Q4, fourth quartile. Abbreviations: $\mathrm{mg} / \mathrm{L}$, milligram per liter; ${ }^{\circ} \mathrm{C}$, degree Celsius; $\mu \mathrm{g} / \mathrm{L}$, microgram per liter]

\begin{tabular}{|c|c|c|c|c|}
\hline & \multicolumn{4}{|c|}{ Water column averaged value } \\
\hline & $\begin{array}{c}\text { Dissolved } \\
\text { oxygen } \\
\text { (mg/L) }\end{array}$ & $\begin{array}{c}\text { Temperature } \mathrm{C} \\
\left({ }^{\circ} \mathrm{C}\right)\end{array}$ & $\begin{array}{c}\text { Chlorophyll a } \\
\text { ( } \mu \mathrm{g} / \mathrm{L})\end{array}$ & $\begin{array}{c}\text { Ammonia-N } \\
(\mu \mathrm{g} / \mathrm{L})\end{array}$ \\
\hline \multicolumn{5}{|l|}{ Percentile } \\
\hline 95th & 8.03 & 23.4 & 314 & 1,170 \\
\hline 90th & 7.51 & 22.9 & 256 & 1,090 \\
\hline 75 th & 6.54 & 21.8 & 148 & 898 \\
\hline 50 th & 4.72 & 20.4 & 100 & 313 \\
\hline 25 th & 3.72 & 19 & 60 & 86 \\
\hline 10th & 2.16 & 17.9 & 24 & 29 \\
\hline 5 th & 1.21 & 17.3 & 14 & 19 \\
\hline \multicolumn{5}{|c|}{ Values on dates closest to fish die-offs } \\
\hline $07-28-03$ & 0.6 & 24.3 & 28 & 907 \\
\hline Quartile & Q1 & Q4 & Q1 & Q4 \\
\hline $08-20-96$ & 5.16 & 19.7 & 64 & 979 \\
\hline Quartile & Q3 & $\mathrm{Q} 2$ & Q2 & Q4 \\
\hline 08-12-97 & 4.3 & 21.1 & 44 & 803 \\
\hline Quartile & Q2 & Q3 & Q1 & Q3 \\
\hline
\end{tabular}

counted after stratification had collapsed. It also was apparent in the difference between 2002 and 2003 in this study. Although 2003 probably was a lower-than-average wind speed year, it was not a year characterized by an exceptional degree of dissolved oxygen stratification, particularly in July, when the most severe LDOE occurred. Indeed, one of the things that made the event exceptional was the fact that stratification was weak and dissolved oxygen was low throughout the water column. In 2002, which also was a lower-than-average wind speed year, the water column was more consistently stratified in dissolved oxygen and to a greater degree than in 2003, and for the most part endangered suckers persisted in the study area and, apparently, survived.

An extended period of dissolved oxygen stratification in the early to mid-summer could increase the risk of a fish die-off several weeks later. For example, low dissolved oxygen in the lower water column could present chronic stress to fish that weakens them and makes them more susceptible to adverse conditions later in the summer. Low winds also may play a role in bloom dynamics, in that even moderate stratification tends to provide favorable conditions for AFA, thus leading to higher biomass and more dramatic bloom declines. From what we can determine from the available data,
Table 15. Distribution statistics of water column averages of chlorophyll $a$, ammonia- $\mathrm{N}$, dissolved oxygen, and temperature at Midnorth site, based on July-August sampling dates, Upper Klamath Lake, Oregon, 1990-2004.

[Water-quality data are biweekly values of chlorophyll $a$ and nutrients, and biweekly profiles of dissolved oxygen collected by the Klamath Tribes at Eagle Ridge in Upper Klamath Lake during July and August 1990-2004. Quartile: Q1, first quartile; Q2, second quartile; Q3, third quartile; Q4, fourth quartile. Abbreviations: $\mathrm{mg} / \mathrm{L}$, milligram per liter; ${ }^{\circ} \mathrm{C}$, degree Celsius; $\mu \mathrm{g} / \mathrm{L}$, microgram per liter]

\begin{tabular}{ccccc}
\hline & \multicolumn{4}{c}{ Water column averaged value } \\
\cline { 2 - 5 } & $\begin{array}{c}\text { Dissolved } \\
\text { oxygen } \\
\text { (mg/L) }\end{array}$ & $\begin{array}{c}\text { Temperature Chlorophyll a } \\
\left.\text { ( }{ }^{\circ} \mathbf{C}\right)\end{array}$ & $\begin{array}{c}\text { Ammonia-N } \\
\text { ( } \mathbf{\mu g} / \mathbf{L})\end{array}$ & $\begin{array}{c}\boldsymbol{\mu} \mathbf{g} / \mathbf{L}) \\
\text { Percentile }\end{array}$ \\
95th & 10.1 & 23.1 & 252 & 982 \\
90th & 9.3 & 22.7 & 240 & 952 \\
75th & 8.8 & 21.8 & 159 & 520 \\
50th & 7.8 & 20.4 & 107 & 121 \\
25th & 6.2 & 19 & 65 & 21 \\
10th & 4.5 & 17.6 & 37 & 5 \\
5th & 4 & 17.2 & 13 & 5 \\
\hline & Values on dates closest to fish die-offs & \\
\hline 07-28-03 & 1.86 & 24.36 & 7 & 873 \\
Quartile & Q1 & Q4 & Q1 & Q4 \\
08-20-96 & 5.33 & 20.05 & 52 & 757 \\
Quartile & Q1 & Q3 & Q1 & Q4 \\
08-12-97 & 4.49 & 21.51 & 36 & 640 \\
Quartile & Q1 & Q3 & Q1 & Q4 \\
\hline
\end{tabular}

these possibilities seem applicable to the 1996 and 1997 fish die-offs, but the fact remains that in 2003, when the die-off began at the end of July, it was not preceded by a period of several weeks of exceptional dissolved oxygen stratification.

If there is a common set of conditions that link all the fish kill years, it seems possible, if not likely, that the correspondence between low wind speeds and fish die-off years has a different significance. One possibility is that interannual variability in wind stress influences interannual variability in water quality through the wind-driven circulation. Oxygen production and consumption varies around the lake, in part as a consequence of the changes in bathymetry that water encounters along a flow path. Because the wind-driven circulation is responsive to wind stress, lower wind speeds slow down the overall wind-driven circulation relative to higher wind speeds and increase residence time in different areas of the lake, providing, in general, more time for both oxygen demanding and oxygen producing processes to act in different areas of the lake. Understanding how the nonconservative processes interact along a flow path as water circulates around the lake faster or slower in response to wind stress is difficult using data from a fixed-site sampling strategy, and likely will require the use of a computer model. 
In addition to the role that low winds may play in the development of an LDOE, it is clear that any severe LDOE, and consequently any fish die-off, will be coincident with a dramatic decline in the AFA bloom. Not only do the senescing cells provide water column oxygen demand, but the shutdown in photosynthetic production also is significant, as water column and sediment oxygen demanding processes continue to consume oxygen. Because, however, the trigger for a dramatic bloom decline is not well understood, we are still unable to determine the root cause of a severe LDOE. An important area of future research will be to try to better understand what causes the AFA bloom to decline, especially when it does so precipitously. Although the cause of AFA bloom declines remains undetermined, we have been able to determine some characteristics of a severe LDOE that all fish die-off years have in common with each other, but with few other nondie-off years. Water coming through the trench and into the northern part of the lake during these events was characterized by exceptionally low water-column averaged dissolved oxygen and chlorophyll $a$ in combination with exceptionally high ammonia, indicating that nearly all AFA biomass had already been converted to inorganic form, in the process consuming nearly all available oxygen. An additional characteristic seems to be high temperature, which can accelerate the respiratory and decay processes that consume oxygen.

\section{Summary}

Monitoring data collected during a 3-year study of sucker behavior in response to water quality provided an opportunity to describe water quality in the study area (approximately the northern one-third of Upper Klamath Lake) at a spatial and temporal resolution that was unavailable prior to 2002 . Several questions were addressed using these data: What is the seasonal and interannual variability in water quality? Are there any aspects of seasonal variability that are predictable? If poor water quality is defined as conditions that would be potentially harmful to endangered suckers, where do these conditions tend to occur and how are they distributed throughout the day? What is the spatial extent of poor water quality conditions? Are there predictable differences in water quality between deep and shallow sites?

Each of the 3 years of the study was unique in terms of the seasonal patterns in water quality and the occurrence and severity of poor water-quality conditions, indicating that little predictability can be expected in these from year to year. Potentially harmful $\mathrm{pH}$ conditions, defined as greater than 9.7, occurred in late June and early July of all 3 years, coincident with a rapid expansion of the first bloom of the season. When averaged by Julian week, the spatial extent of these conditions was the greatest in the first or second week in July in all 3 years, reaching 0,8 , and $47 \mathrm{~km}^{2}$ (square kilometers) to less than 9.7 around mid-July in all 3 years, and only in 2003 did $\mathrm{pH}$ increase again to values greater than
9.7, coincident with a second bloom from the second week in August through the first week in September. Temperatures peaked in late July in all 3 years, but the spatial extent of potentially harmful temperatures, defined as greater than 28 degrees Celsius, was negligible in all 3 years. Dissolved oxygen was the most variable of the three continuously monitored water-quality constituents, as it is determined in large part by bloom dynamics, which also are highly variable from year to year. In each year, there were several periods that could be termed "low dissolved oxygen events" (LDOE) on the basis of the occurrence of concentrations less than $4 \mathrm{mg} / \mathrm{L}$ (milligrams per liter). Concentrations less than $4 \mathrm{mg} / \mathrm{L}$ in the lower water column for part of the day were common during the 3 study years, but did not result in a fish die-off. The most severe LDOE, which did culminate in a fish die-off, occurred in 2003. This LDOE was characterized by concentrations that were $3 \mathrm{mg} / \mathrm{L}$ or less throughout the water column and that persisted throughout the day, for 8 days, at a site located centrally in the study area and the area of the lake that was preferred adult sucker habitat. The maximum spatial extent of weekly averaged concentrations less than $4 \mathrm{mg} / \mathrm{L}$ occurred in the week starting on July 27, 2003, and was $39 \mathrm{~km}^{2}$. The next highest spatial extent of these potentially harmful dissolved oxygen conditions was $17 \mathrm{~km}^{2}$ and occurred in the week starting on August 15 in 2004.

There were differences between deep (defined roughly as deeper than 2.5 meters) and shallow sites in the daily timing of the most extreme values of temperature, $\mathrm{pH}$, and dissolved oxygen, although the timing at both deep and shallow sites was consistent from year to year. At shallow sites, temperature and $\mathrm{pH}$ tended to peak in the late afternoon, primarily between the hours of 5 p.m. and 7 p.m. The daily minimum in dissolved oxygen tended to occur in the early morning hours, before the sun was high in the sky and when dark respiration had been operating the longest, between the hours of about 6 a.m. and 8 a.m. At deep sites, the timing of extreme values of temperature and $\mathrm{pH}$ was in the late afternoon, as at the shallow sites, but the timing of the extreme values of dissolved oxygen was less well defined than at the shallow sites. This is because the deeper sites often experience some degree of thermal stability during the day. Dissolved oxygen can continue to decrease in the lower water column beyond the early morning hours due to ongoing respiratory and other oxygen demanding processes in the water column and sediments, until at some point the water column mixes when the wind picks up or the water surface cools sufficiently. As a result, there was no well-defined time window in which the minimum daily dissolved oxygen concentration tended to occur at the deeper sites. Because low dissolved oxygen conditions tend to be more extreme at the deeper sites, and concentrations potentially harmful to fish are most likely to occur at the deeper sites, the assumption, sometimes made, that the worst conditions of the day for fish (in terms of dissolved oxygen) occur in the early morning hours probably is not justified in this lake. 
Because hypoxia was determined to be an important trigger of recent, documented fish die-offs, a section of this report was devoted to discussing the factors contributing to an LDOE. Exceptional stratification in dissolved oxygen and low wind stress were not consistent features of the observed LDOEs, but the most severe LDOEs were coincident with a bloom decline.

Because the cause for bloom declines is unknown, the fundamental cause of a severe LDOE remains undetermined, but it was determined that severe LDOEs in the northern part of the lake for the most part do not develop there, but rather develop to the south and are transported into the area by the wind-driven circulation. The placement of acoustic Doppler current profilers in the lake in conjunction with the collection of wind data showed decisively the close coupling between the currents in the lake and the surface wind stress, and the fact that under prevailing wind conditions most of the volume of the lake moves in a clockwise loop that is completed in about 10 days. Water enters the northern part of the lake, where the preferred sucker habitat is found, almost entirely through a small cross-section between Eagle Ridge and Bare Island. Water coming through that cross section during the most severe LDOE, in July 2003, was characterized by exceptionally low water-column averaged dissolved oxygen, exceptionally low chlorophyll $a$, and exceptionally high temperature and ammonia.

The concentration of dissolved oxygen observed at a fixed site on the lake is a complicated function of the wind-driven circulation. Reversals or stalls in the wind increase the residence time in the deep trench along the western shoreline, thus allowing more time for oxygen demanding process to deplete the water passing through of oxygen. These stalls or reversals increase residence time along the northern and eastern broad shallow areas of the lake as well, thus giving oxygen producing photosynthesis more time to increase dissolved oxygen concentration in those areas. Short-term pulses of water low in dissolved oxygen coming through the trench were linked directly to brief wind reversals. Long-term trends in water quality, on a time scale greater than about 10 days, integrate the net effect of all oxygen demanding and oxygen producing processes along the flow path. It was such a trend that culminated in the severe July 2003 LDOE.

An attempt was made to place the 3 study years into a more historical context and, in particular, to the characteristics that distinguish the three most severe recent fish die-off years (1996, 1997, and 2003). A 15-year record of meteorology (air temperature and wind speed collected at the Klamath Falls airport, obtained from the National Climatic Data Center) and water quality (biweekly water-quality profiles collected at three sites in the northern part of the lake by the Klamath Tribes) were used to provide the historical context. Air temperature was used as a surrogate for water temperature, as no long-term continuous records of water temperature exist. Two of the three fish die-off years, 1996 and 2003, ranked at the high end of the range in July temperature, and 1996 and 1997 ranked at the high end of the range in August temperature, on the basis of an analysis of variance test (ANOVA). Thus, high temperatures may contribute to the conditions leading to a fish die-off. The same test ranked all 3 fish die-off years at the low end of the range in July wind speeds. An attempt to correlate wind stress with the degree of dissolved oxygen stratification or with dissolved oxygen concentration using the 15 years of climate data yielded insignificant relations, so the contribution of lowerthan-average wind stress to a severe LDOE or a fish die-off probably is not through stratification, but rather something else, possibly the wind-driven circulation.

Attempts were made to rank July-August median water-quality variables in the biweekly dataset collected by the Klamath Tribes with an ANOVA. Most water-quality variables had short term and spatial variability comparable to interannual variability, making it difficult to statistically distinguish July-August distributions between years. The exception was ammonia concentration, which showed year-to-year trends in the July-August distributions suggestive of a climatic signal. The ammonia concentration was highly correlated with two climate variables - mean July-August wind speed, and October to May cumulative discharge in the Williamson River. Because both climate variables were also correlated with May-June ammonia concentration, the correlation with Williamson River discharge is more likely to represent a causal relation, such as high spring runoff bringing in more readily decomposed material, resulting in a higher water column ammonia concentration in late spring and early summer. It is unclear, however, that there is any connection between the climate signal in ammonia concentration and the occurrence of fish die-offs. One of the three fish die-off years, 1997, was characterized by some of the highest ammonia concentrations on record, one year, 1996, was characterized by more moderate, but still high (relative to the entire 15-year record) concentrations, and one year, 2003, was characterized by some of the lowest concentrations in the 15-year record.

Even though fish die-off years were not all years of exceptionally high ammonia concentration, high ammonia concentration (in the fourth quartile of the entire historical distribution of July-August values) at a single index site located in the study area was one of three factors that, in combination, could be used to successfully screen the historical water-quality dataset for those dates which most closely preceded the fish die-offs. The other two factors were dissolved oxygen and chlorophyll $a$ concentration, both in the first quartile. Dates preceding the fish die-offs in all 3 years were passed by the screening, and dates from only three other non die-off years were passed by this screening. Therefore, the idea that one site could act as an "indicator" site was deemed a success, which might be information that could be used in the design of a long-term monitoring program for the lake. 


\section{Acknowledgments}

The commitment of Rip Shively and Scott Vanderkooi from the USGS Klamath Falls Field Station to facilitating the water quality field program is gratefully acknowledged. Jeff Gartner from the USGS National Research Program was responsible for the deployment of the ADCPs in the lake. Ralph Cheng from the USGS National Research Program provided the hydrodynamic modeling results that greatly improved our interpretation of the water quality observations. Many people contributed to the field work over the 3 years of this study, and their efforts are gratefully acknowledged: Jason Cameron, Michael Berg, and Jessica Asbill from the Bureau of Reclamation in Klamath Falls; Daniel Gambetta, Anna Glass, April McKellar, Michael Altmayer, Anthony Ordway, Pamela Burns, Jim Harris, Melissa Berhardt, and Christine Adelsberger, from the USGS in Klamath Falls; Matt Johnston and Micelis Doyle from the USGS in Portland. Reviews by Greg Fuhrer, Dale Robertson, Tara Shraga, and John Williams greatly improved the first draft of the manuscript.

\section{References Cited}

Blank, J., and Juza, B., 2001, Hydrodynamic modeling of Upper Klamath Lake: Corte Madera, Calif., Phillip Williams and Associates, Ltd., report no. 1507 prepared for Bureau of Reclamation, $20 \mathrm{p}$.

Bureau of Reclamation, 1997, AgriMet-The Pacific Northwest cooperative agricultural weather network: accessed March 27, 2006, at http://www.usbr.gov/pn/agrimet/.

Gartner, J.W., and Ganju, N.K., 2002, A preliminary evaluation of near-transducer velocities collected with lowblank acoustic Doppler current profiler, in Wahl, T.L., Pugh, C.A., Oberg, K.A., and Vermeyen, T.B., eds., Proceedings of the Hydraulic Measurements and Experimental Methods 2002 Conference, July 28-August 1, 2002, Estes Park, Colo.: Amercian Society of Civil Engineers.

Helser, T.E., Loftus, M.E., Hendrix, N., Reiser, D.W., 2004, A Bayesian risk analysis of unsuitable dissolved oxygen concentrations in Upper Klamath Lake-Model development and application: Redmond, Wash., R2 Resource Consultants, Inc., from Compendium of Technical Memoranda 1450.08.

Horowitz, A.J., Demas, C.R., Fitzgerald, K.K., Miller, T., and Rickert, D.A., 1994, U.S. Geological Survey protocol for the collection and processing of surface-water samples for the subsequent determination of inorganic constituents in filtered water: U.S. Geological Survey Open-File Report 94-539, $57 \mathrm{p}$.

Johnson, D.M., Petersen, R.R., Lycan, D.R., Sweet, J.W., Neuhaus, M.E., and Schaedel, A.L., 1985, Atlas of Oregon Lakes: Corvallis, Oregon State University Press, 317 p.
Kann, J., and Welch, E.B., 2005, Wind control on water quality in shallow, hypereutrophic Upper Klamath Lake, Oregon: Lake and Reservoir Management, v. 21, no. 2, p. 149-158.

Loftus, M.E., 2001, Assessment of potential water quality stress to fish, Supplement to effects of water quality and lake level on the biology and habitat of selected fish species in Upper Klamath Lake: Redmond, Wash., R2 Resource Consultants, Inc., report prepared for the Bureau of Indian Affairs, Portland, Oreg.

National Climatic Data Center, 2006, Get/View Online Climate Data: accessed March 27, 2006, at http://lwf.ncdc. noaa.gov/oa/climate/climatedata.html.

Oliver, R.L. and Ganf, G.G., 2000, Freshwater blooms, in, Whitton, B.A. and Potts, M., eds., The ecology of Cyanobacteria, Their diversity in time and space: Dordrecht, Kluwer Academic, p. 149-194.

Perkins, D.L., Kann, J., and Scoppettone, G.G., 2000, The role of poor water quality and fish kills in the decline of endangered Lost River and shortnose suckers in Upper Klamath Lake: Klamath Falls, Oreg., U.S. Geological Survey Final Report submitted to Bureau of Reclamation Klamath Falls Project Office, Contract 4-AA-29-12160.

Reiser, D.W., Loftus, M., Chapin, D., Jeanes, E., and Oliver, K., 2000, Effects of water quality and lake level on the biology and habitat of selected fish species in Upper Klamath Lake: Redmond, Wash., R2 Resource Consultants, Inc., report prepared for the Bureau of Indian Affairs, Portland, Oreg.

Saiki, M.K., Monda, D.P., and Bellerud, B.L., 1999, Lethal levels of selected water quality variables to larval and juvenile Lost River and shortnose suckers: Environmental Pollution, v. 105, p. 37-44.

U.S. Environmental Protection Agency, 1998, Update of ambient water quality criteria for ammonia: U.S. Environmental Protection Agency Office of Water report EPA 822-R-98-008.

U.S. Environmental Protection Agency, 2006, Technology transfer network air quality system (AQS): accessed March 27, 2006, at http://www.epa.gov/ttn/airs/airsaqs/index.htm.

U.S. Geological Survey, no date, NWISWeb-Surface-water data for Oregon: accessed March 27, 2006, at http:// waterdata.usgs.gov/or/nwis/sw.

U.S. Geological Survey, variously dated, National field manual for the collection of water-quality data: U.S. Geological Survey Techniques of Water-Resources Investigations, book 9, chaps. A1-A9, varioiusly paged, accessed March 20, 2006, at http://pubs.water.usgs.gov/twri9A.

Wagner, R.J., Mattraw, H.C., Ritz, G.F., and Smith, B.A., 2000, Guidelines and standard procedures for continuous water-quality monitors-Site selection, field operation, calibration, record computation, and reporting: U.S. Geological Survey Water-Resources Investigations Report 00-4252, $53 \mathrm{p}$.

Wood, T.M., 2001, Sediment oxygen demand in Upper Klamath and Agency Lakes, Oregon, 1999: U.S. Geological Survey Water-Resources Investigations Report 01-4080, 13 p. 


\section{Appendix A. Quality-Assurance Data for Water Samples}

Table A1. Blank sample results for the water-quality sample collection program.

[Abbreviations: $\mathrm{mg} / \mathrm{L}$, milligram per liter; NA, not applicable]

\begin{tabular}{|c|c|c|c|c|c|c|c|}
\hline \multirow{2}{*}{ Analyte } & \multicolumn{2}{|c|}{ Number of samples } & \multirow{2}{*}{$\begin{array}{l}\text { Percentage } \\
\text { of blank } \\
\text { samples }\end{array}$} & \multirow{2}{*}{$\begin{array}{l}\text { Minimum } \\
\text { reporting } \\
\text { level } \\
\text { (mg/L) }\end{array}$} & \multirow{2}{*}{$\begin{array}{c}\text { Number of blank } \\
\text { samples } \\
\text { greater or } \\
\text { less than } \\
\text { minimum } \\
\text { reporting level }\end{array}$} & \multicolumn{2}{|c|}{$\begin{array}{l}\text { Value of blank samples } \\
\text { greater than minimum } \\
\text { reporting level (mg/L) }\end{array}$} \\
\hline & Blank & Total & & & & Maximum & Median \\
\hline \multicolumn{8}{|c|}{2002} \\
\hline Orthophosphate-P & 18 & 218 & 8 & 0.01 & 10 & 0.03 & 0.02 \\
\hline Ammonia-N & 18 & 218 & 8 & .02 & 18 & NA & NA \\
\hline Nitrate/nitrite-N & 18 & 218 & 8 & .03 & 18 & NA & NA \\
\hline Total phosphorus & 19 & 114 & 17 & .004 & 18 & .007 & NA \\
\hline Chlorophyll $a$ & 1 & 101 & 1 & NA & NA & 2.4 & NA \\
\hline \multicolumn{8}{|c|}{2003} \\
\hline Orthophosphate-P & 24 & 130 & 18 & 0.007 & 20 & NA & NA \\
\hline Ammonia-N & 24 & 130 & 18 & .015 & 9 & 0.202 & 0.032 \\
\hline Nitrate/nitrite-N & 24 & 130 & 18 & .022 & 17 & .038 & .032 \\
\hline Total phosphorus & 16 & 81 & 2 & .004 & 11 & .005 & NA \\
\hline Chlorophyll $a$ & 2 & 62 & 3 & NA & NA & 0 & NA \\
\hline \multicolumn{8}{|c|}{2004} \\
\hline Orthophosphate-P & 21 & 191 & 11 & 0.006 & 0 & NA & NA \\
\hline Ammonia-N & 29 & 199 & 15 & .01 & 7 & 0.188 & 0.034 \\
\hline Nitrate/nitrite-N & 21 & 191 & 11 & .016 & 17 & .037 & .022 \\
\hline Total phosphorus & 22 & 133 & 17 & .004 & 17 & NA & NA \\
\hline Chlorophyll $a$ & 0 & 106 & 0 & NA & NA & NA & NA \\
\hline
\end{tabular}


Table A2. Split sample results for the water-quality sample collection program, 2002-04.

[Abbreviations: $\mathrm{mg} / \mathrm{L}$, milligram per liter]

\begin{tabular}{|c|c|c|c|c|c|}
\hline \multirow{2}{*}{ Analyte } & \multicolumn{2}{|c|}{ Number of samples } & \multirow{2}{*}{$\begin{array}{c}\text { Percentage } \\
\text { of split } \\
\text { samples }\end{array}$} & \multicolumn{2}{|c|}{$\begin{array}{l}\text { Difference between spli } \\
\text { samples }\end{array}$} \\
\hline & Split & Total & & $\begin{array}{c}\text { Median } \\
\text { (mg/L) }\end{array}$ & $\begin{array}{c}\text { Median } \\
\text { (percent) }\end{array}$ \\
\hline \multicolumn{6}{|c|}{2002} \\
\hline Orthophosphate-P & 19 & 218 & 9 & 0.01 & 7.4 \\
\hline Ammonia-N & 19 & 218 & 9 & .02 & 22.2 \\
\hline Nitrate/nitrite-N & 19 & 218 & 9 & 0 & 0 \\
\hline Total phosphorus & 8 & 114 & 7 & .014 & 5.2 \\
\hline Chlorophyll $a$ & 14 & 101 & 14 & 1.6 & 3.4 \\
\hline \multicolumn{6}{|c|}{2003} \\
\hline Orthophosphate-P & 11 & 130 & 8 & 0.004 & 10 \\
\hline Ammonia-N & 11 & 130 & 8 & .02 & 16.9 \\
\hline Nitrate/nitrite-N & 11 & 130 & 8 & 0 & 0 \\
\hline Total phosphorus & 7 & 81 & 9 & .011 & 7.7 \\
\hline Chlorophyll $a$ & 5 & 62 & 8 & 5 & 6.6 \\
\hline \multicolumn{6}{|c|}{2004} \\
\hline Orthophosphate-P & 17 & 191 & 9 & 0.001 & 6.2 \\
\hline Ammonia-N & 17 & 199 & 9 & .002 & 2.9 \\
\hline Nitrate/nitrite-N & 17 & 191 & 9 & .004 & 10.5 \\
\hline Total phosphorus & 7 & 133 & 5 & .006 & 4.6 \\
\hline Chlorophyll $a$ & 7 & 106 & 7 & 11 & 10.3 \\
\hline
\end{tabular}


Table A3. Replicate sample results for the water-quality sample collection program, 2002-04.

[Abbreviations: $\mathrm{mg} / \mathrm{L}$, milligram per liter]

\begin{tabular}{|c|c|c|c|c|c|}
\hline \multirow{2}{*}{ Analyte } & \multicolumn{2}{|c|}{ Number of samples } & \multirow{2}{*}{$\begin{array}{c}\text { Percentage } \\
\text { of replicate } \\
\text { samples }\end{array}$} & \multicolumn{2}{|c|}{$\begin{array}{l}\text { Difference between } \\
\text { replicate samples }\end{array}$} \\
\hline & Replicate & Total & & $\begin{array}{c}\text { Median } \\
\text { (mg/L) }\end{array}$ & $\begin{array}{c}\text { Median } \\
\text { (percent) }\end{array}$ \\
\hline \multicolumn{6}{|c|}{2002} \\
\hline Orthophosphate-P & 12 & 218 & 6 & 0.009 & 10.5 \\
\hline Ammonia-N & 12 & 218 & 6 & .011 & 3.8 \\
\hline Nitrate/nitrite-N & 12 & 218 & 6 & 0 & 0 \\
\hline Total phosphorus & 6 & 114 & 5 & .004 & 2.7 \\
\hline Chlorophyll $a$ & 6 & 101 & 6 & 4.5 & 4.3 \\
\hline \multicolumn{6}{|c|}{2003} \\
\hline Orthophosphate-P & 8 & 130 & 6 & 0.014 & 34.2 \\
\hline Ammonia-N & 8 & 130 & 6 & .046 & 19.4 \\
\hline Nitrate/nitrite-N & 8 & 130 & 6 & .005 & 7.2 \\
\hline Total phosphorus & 5 & 81 & 6 & .014 & 5.6 \\
\hline Chlorophyll $a$ & 4 & 62 & 6 & 4.5 & 11.2 \\
\hline \multicolumn{6}{|c|}{2004} \\
\hline Orthophosphate-P & 15 & 191 & 8 & 0.001 & 13.3 \\
\hline Ammonia-N & 15 & 199 & 8 & .016 & 38.6 \\
\hline Nitrate/nitrite-N & 15 & 191 & 8 & .004 & 12.2 \\
\hline Total phosphorus & 10 & 133 & 8 & .01 & 9.8 \\
\hline Chlorophyll $a$ & 10 & 106 & 9 & 11 & 10.5 \\
\hline
\end{tabular}

Table A4. Spiked sample results for the water-quality sample collection program, 2002-04.

[Abbreviations: NA, not applicable (no analysis)]

\begin{tabular}{lccc}
\hline \multirow{1}{*}{ Analyte } & \multicolumn{3}{c}{$\begin{array}{c}\text { Average percentage recovery } \\
\text { of spiked samples }\end{array}$} \\
\cline { 2 - 4 } & $\mathbf{2 0 0 2}$ & $\mathbf{2 0 0 3}$ & $\mathbf{2 0 0 4}$ \\
\hline Orthophosphate-P & 112 & 106 & 92 \\
Ammonia-N & 114 & 94 & 98 \\
Nitrate/nitrite-N & 100 & 90 & 97 \\
Total phosphorus & NA & 100 & 104 \\
\hline
\end{tabular}


SPLIT SAMPLES
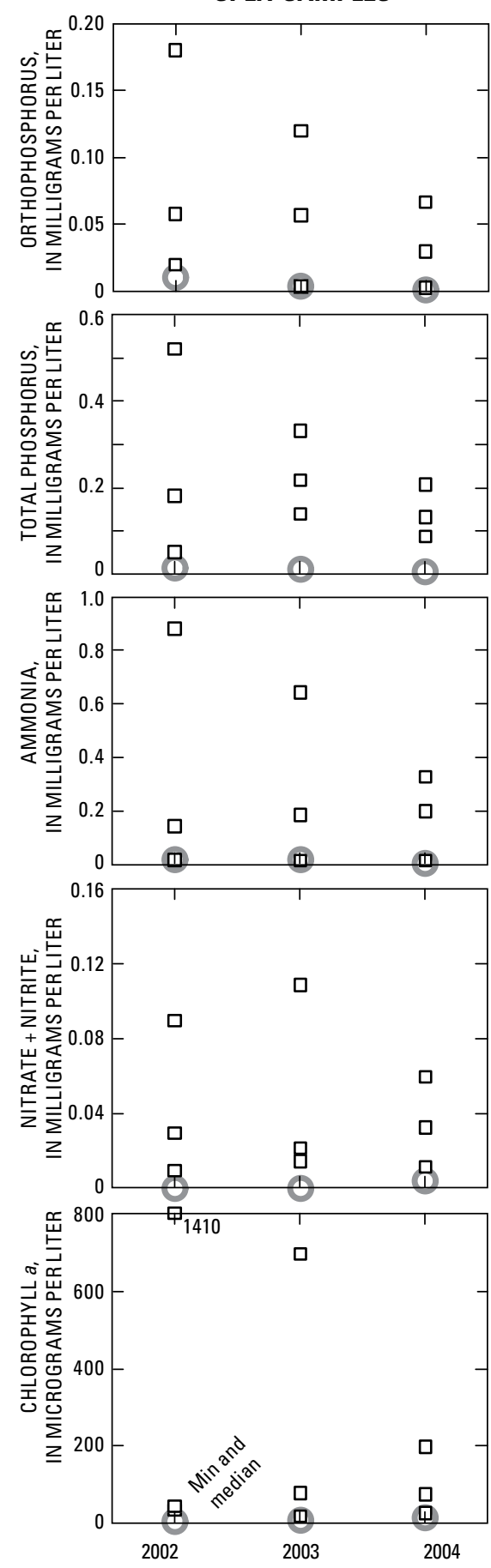

REPLICATE SAMPLES
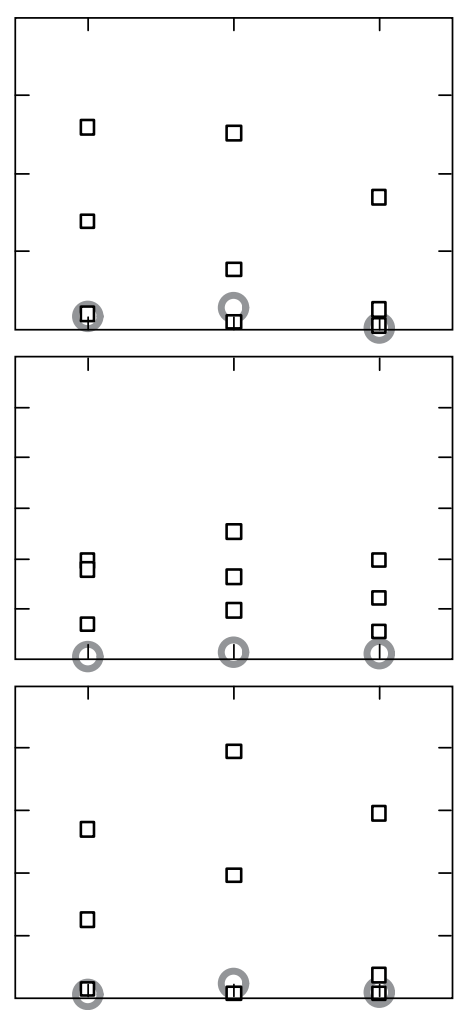

口
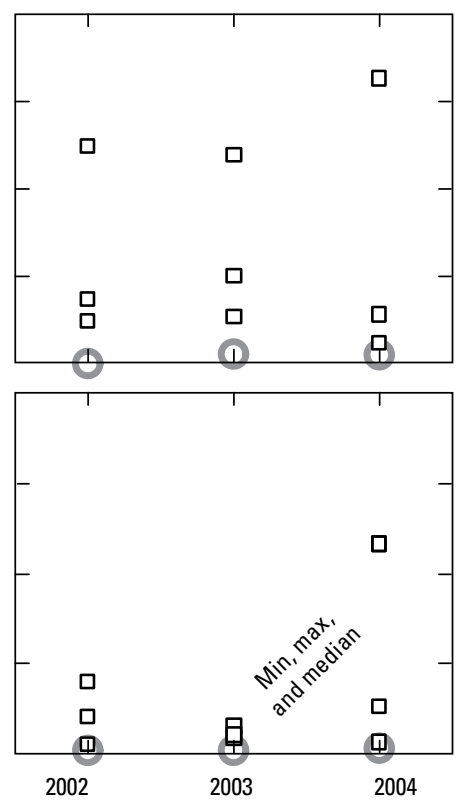

\section{EXPLANATION}

Median of the difference between splits or replicates

$\square$ Minimum, maximum, and median values of environmental samples

Figure A1. Median of the difference between replicate and split samples, compared to the distribution of the environmental samples. 
Manuscript approved for publication, August 15, 2006

Prepared by the USGS Publishing Network,

Publishing Service Center, Tacoma, Washington

Donita Parker

Linda Rogers

Sharon Wahlstrom

Bobbie Jo Richey

For more information concerning the research in this report, contact the Director, Oregon Water Science Center

U.S. Geological Survey

10615 SE Cherry Blossom Drive

Portland, Oregon 97216

http://or.water.usgs.gov 
